Gergely Fábián (Ed.)

Andrea Toldi (Ed.)

\title{
THE CHANGING FACES OF SOCIAL ECONOMY ACROSS EUROPE: A PERSPECTIVE FROM 7 COUNTRIES
}

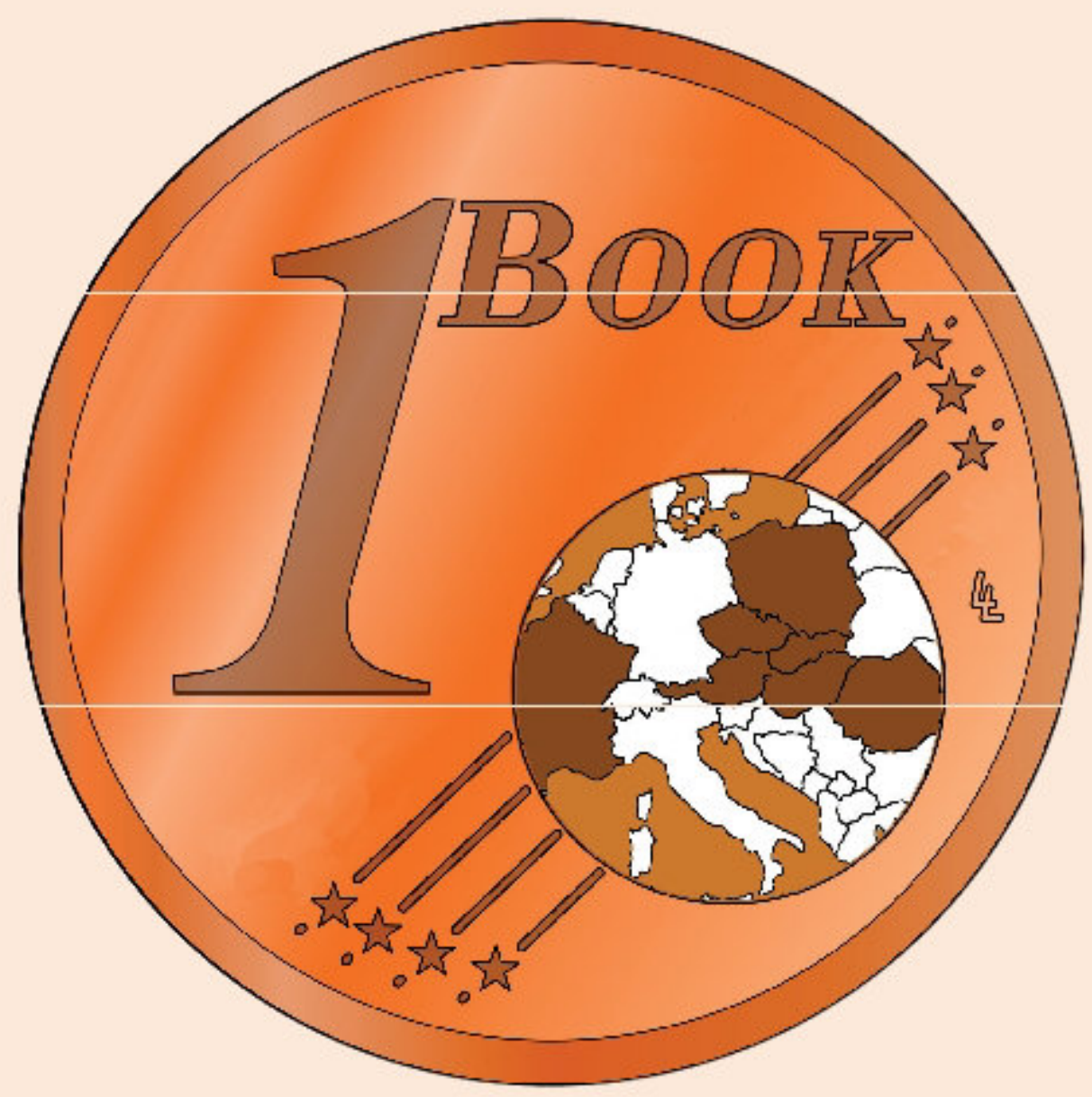




\section{University of Debrecen \\ Faculty of Health}

\section{Gergely Fábián (Ed.) Andrea Toldi (Ed.)}

\section{THE CHANGING FACES OF SOCIAL ECONOMY ACROSS EUROPE: A PERSPECTIVE FROM 7 COUNTRIES}

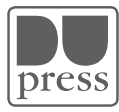

Debreceni Egyetemi Kiadó Debrecen University Press 2016 


\title{
List of Contributors:
}

Anna Delage, Yves Coutand, Gerhard Melinz, Astrid Pennerstorfer, Brigitta Zierer, Ondrej Botek, Šárka Ulčáková, Śárka Dořičáková, Witold Mandrysz, Adina Rebeleanu, Livia Popescu, László Patyán,

\author{
Reviewers: \\ Prof. Dr. Mihály Fónai \\ Dr.Béla Szabó \\ Prof. Dr. Thomas R. Lawson
}

Technical editor:

Béla Ricsei

Cover designed by

Andrea Toldi

Graphic Artist

Béla Ricsei

DOI 10.5484/fabian_toldi_changing_faces

\section{(9) $(1) \Theta \Theta$}

(C) Debreceni Egyetemi Kiadó Debrecen University Press,

All rights reserved including

electronic distribution rights within the university network too, 2016

ISBN 978-963-318-569-8

Published by Debreceni Egyetemi Kiadó Debrecen University Press www.dupress.hu Publisher: Gyöngyi Karácsony

Made in the duplicating plant of the University of Debrecen in 2016 


\section{Contents}

Preface

(Gergely Fábián, Andrea Toldi)

Social and Solidarity Economy in France

(Anna Delage, Yves Coutand)

Social Economy and Social Work in Austria

(Gerhard Melinz, Astrid Pennerstorfer, Brigitta Zierer)

Social Policy and Social Economy in Slovakia

(Ondrej Botek)

Social Economy in the Czech Republic

(Šárka Ulčáková)

Social Enterprise in the Czech Republic

(Š́rka Dořičáková)

Social Economy in Poland - Overview of the Development and Current Situation of Social Economy Entities

(Witold Mandrysz)

Development of Social Economy in Romania

(Adina Rebeleanu, Livia Popescu)

Social Economy, Social Work in Hungary

(László Patyán)

List of Contributors 



\section{Preface}

The professors from each country participating in the SOWOSEC (Social Work and Social Economy) Joint Degree Program fill a unique niche by discussing the characteristics of social economy in their respective countries. The purpose of this book is to define social economy within a national context and to elucidate the different forms, conditions and ways, institutions and actors in social economy function in these countries.

The members, universities and institutes of SOWOSEC have been working together since 2005 developing and implementing a European joint degree master's program that significantly widens the knowledge and competencies achieved in different bachelor programs. The philosophy of the program is as follows:

Due to the current social and economic changes throughout the social sphere, there is a growing demand that social service providers should adjust social provision to the economy. The aim of this program is to provide professionals working in the social field with economic knowledge and skills so that they would be able to plan and organize the economics of service planning, delivery and management. 
International co-operation is needed in order to manage modern services within the social economy, and respond to the changes taking place across Europe. The joint degree offers a great variety of competencies needed in this field.

The philosophy behind this training is rather complicated, namely to enable social providers and academic institutions to successfully adjust to the changes caused by the cut of state resources and be able to manage, obtain resources, and make the organizations, as well as their programs and services well-known by the public. After acquiring the knowledge and standards of social work in the Bachelor program, students in SOWOSEC learn how to plan effective economic frameworks for social institutions and services. This master degree program joins the sometimes-divergent social and economic philosophy of social with respect to the professions and European standards.

The program was established and is presently operating in several countries (Austria, Germany, Hungary, Poland, the Czech Republic, Slovakia, Romania with the help of French and Swiss insitutions involved). Therefore the professors have decided to launch a scientific-professional book series, which thematically provides an overview of the characteristics, actors and future possibilities of the social economy.

The first volume introduces the definitions, as well as the legal-economic-social conditions that have developed in each country. The authors give an overview of the historical dimensions of social economy as well. Although experts interested 
in this topic know that no uniformly accepted terminology of social economy can be found in Europe, this book will provide a coherent picutre of the similarities and differences of the interpretations and systems of each member country, as well as the common ground where the Western and Eastern countries (although with different economic-historical-social backgrounds) do have a common platform in the field of social economy. The individual studies contain the crucial information about the topic but introduce various examples of best practice which is particularly useful to the understanding of the different (or similar?) practices of social economy.

The book provides assistance to the students' studies but also to a much broader audience. For those who are interested in the current stage of each participating European country they can learn what steps those countries have taken to establish and develop a system of social economy. In this illuminating process common content and organizational elements are uncovered even when there are national differences.

The authors of the book have created a thorough, scientific and professional book to improve education. Additionally the authors congratulate their Hungarian partner, the University of Debrecen, Faculty of Health on the celebration of its 25th anniversary. These congratulations also include the 25th anniversary of social work training that was created at the time of the founding of the faculty. The professors of the social work training in the Faculty of Health 
are also founders of the SOWOSEC program and have been working together with their foreign partners since its inception. Students and the lecturers of the Faculty can receive the groups's first volume of the SOWOSEC book series as a birthday present, which will assist in education and also be a unique and significant contribution to the scientific background of the program.

Gergely Fábián, Andrea Toldi 


\section{Social and Solidarity Economy in France}

\section{Anna Delage, Yves Coutand}

The Social and Solidarity Economy has a long history, it is built as an answer to our social needs. It is a way to remind us that the liberal, conservative and capitalist economy is not the only choice for our society.

The dilemma or the tension between the two poles of economic and social is the basis of the social economy movement in France. To be more precise it might be appropriate to say that the invention of "Social" (as an issue of policy) in the second half of the nineteenth century was an attempt to solve the tension between economics and politics that had been released by the French Revolution. On a night in August 1789, the young republic created sovereignty of the people and abolished privileges of the dominant orders, aristocracy and clergy, but, one century later, she had not been successful in concretely satisfying the needs of these sovereign people to gain access to work, justice and social security.

In France we talk about "ESS" (Social and Solidarity Economy) but we make a distinction between Social Economy and Solidarity Economy ("fair economy"). Social Economy is quite specific to European countries; it focuses more on what is common among the members in organizations, rather than the capital distribution and accumulation. The Solidarity Economy appeared in France in the 1980's and brought a social and political understanding based on initiatives. Most of the activities developed in the Solidarity Economy appear in civil society. We consider all citizens equal, working for the same goal, known as solidarity. The Solidarity Economy includes more business sectors/organizations than the Social Economy in France. The understanding of the Solidarity Economy comes from the historical definition of Social Economy ${ }^{1}$. 
The term social economy derives from the French économie sociale, a term first recorded in about 1900. There, the sector usually consists of four organizational groups: co-operatives, mutual insurance companies, associations (voluntary organizations) and foundations (which must be recognized as 'public utility' in France). Social economy is a major sector in France, it represents $12 \%$ of the employment and also $12 \%$ of the GDP.

\section{The historical origin of social and solidarity economy Associations of free workers in the 19th century}

There is not enough place here to describe the richness and diversity of the sometimes tragic history of social movements in the nineteenth century, but this is where the great ideologies, Liberalism and Marxism, which determined the destiny of the twentieth century, were falsified. However, we must go back to this episode of the story to understand the emergence of a kind of a "third way" between the above mentioned opposite poles, in the context of the development of industrial capitalism, the completely unbridled social disorder caused by rapid urbanization around major industrial and commercial centers.

The 19th century is the century of the industrial development and of the liberal capitalism. Cities are growing around factories and a new working class, the proletarians, appears. Working conditions in the factories are bad: no laws, no regulations to protect workers from the new requirements of productivism. Outside the factory, in the cities, poor housing, poverty and disorganization threaten the health of the working classes.

To fight against the difficulties generated by this savage capitalism, to protect themselves from exploitation, and risks of accidents and diseases, workers create 
mutual aid associations, and labor cooperatives inspired from the old trade organisations like corporations and guildes abolished in 1791 by the law Le Chapelier. At the same time, riots and strikes are calling on state governement to apply the values of liberty, equality and justice promoted by the democratic revolution of 1789. This riots will be repressed violently by the conservative government during the revolution of 1848 .

Many writers and thinkers of modern society support this movement. Here are some citations:

The lesson of St Simon is strict:

"The economic facts void the politics"

"Political economy, a science of the wealth of nations which are starving" Victor Considerant (1808-1893)

"Democracy in the political and the almost absolute monarchy in the workshop are two facts that cannot coexist longer" (Anthime Corbon "The Workshop" 1849)

Neither the declaration of human rights or the political democracy is sufficient by themselves, the issue of poverty and the exploitation of the workers is thus inseparable from a more general question:

"How now reconstruct society on new bases, reinventing forms of solidarity that are neither organic (traditional) or purely individualistic and contractual... Fraternal societies, associations of free workers. From this crucible of popular initiatives will be born, fast enough, unions and the status of organizations that theorists call the social economy ....1848 is the first moment of meeting, prepared since 1830, between the working class, the first socialist theorists and the Republic " (Chanial Laville, 2000). 


\section{Different ways of thinking about social economy}

St. Simon, Owen, Fourier, Proudhon, Louis Blanc... their popular initiatives have inspired all Europe and many thinkers of the time, and even since then they have also inspired politicians, republican leaders, economists, philanthropists or religious, secular, revolutionary people both radicals and moderates. They can be grouped around four or five major schools of thought: Pragmatic socialism (Proudhon, Owen): Cooperatives for production and consumption - Social Christianity ( Buchez, Raiffeisen): Credit unions, production association - Republican Solidarism (Bourgeois, Gide) : Mutualism and social protection - Liberalism: (Schulze-Delitzsch) : Popular Banks, Savings banks - Utopian socialists (Fourier, Godin) A self-sustaining cooperative community (of the followers of Fourierism), also called phalanx.

Whatever the diversity of approaches is they have two characteristics

- The voluntary, religious or secular approach, rooted in a claim belonging to a community strengthened by the implementation of an economic activity - The action is part of the construction of a democratic society and is involved in public space.

In the history of the labor movement and the trade unions the option of Marxist collectivism will finally prevail among the workers and they will be separated from the reformist branch, accusing the cooperatives of producing gentrification as it hires employees who are not associated or refuse new members.

"The contrast between the labor movement and the cooperative movement is probably rooted in the law of 1884 (Law Waldeck Rousseau) that recognizes freedom of associations, but by restricting trade unions to the defense of work- 
ers, prohibiting them to manage economic activities directly (unlike their German counterparts) ${ }^{\prime \prime}$

\section{Toward the welfare state: the institutionalization of Social Economy}

During the second half of the nineteenth century, with extending the associationist movement the struggles lead to compromises legalizing the existence of organizations with different legal statutes in which a group of agents, other than investors gets the status of beneficiaries. These organizations will gradually be defined as social economy organizations. Social economy is therefore seen as a sector including the statutes of cooperatives, mutual insurance companies, associations, where it is not the constraint of non profit is important but the fact that the material interests of capital providers is limited.

The connection of these statutes to different organizations, which are considered to be parts of the same associationist genesis, and to which the unions should be attached too, caused that the French concept of social economy is different from the English concept of the nonprofit sector. In the French design, the border is not between organizations with or without profit, but between the capitalist societies and the social economy organization which, putting a priority to the settlement of a collective heritage rather than to the individual return on investment, restricts the private ownership's results.

The approach of the social economy values this recognition, but in doing so, it hides the entry in an institutional architecture based on the separation between "economy" defined as a market and "social" defined as under the state responsibility." (Chanial Laville, 2000).

1

« Histoire de la coopération professionnelle» coop.fr 
So, finally, under the third republic and after the disaster of "the Commune", the workers, by their struggles, get the recognition of a part of their rights by the laws institutionalizing the status of trade-unions and the status of social economy organizations (cooperatives, mutual insurance companies, associations).

At the same time, the concept of solidarity gets a new sense. Under the influence of lawyers, sociologists and politicians, all from the republican bourgeoisie, solidarity becomes a national duty. The ideology of solidarism, theorized by Leon Bourgeois, defines solidarity as a social debt toward the previous and future generations. This social debt is regulated by the state through the game of redistribution of income collected on results of labor (wages).

Solidarism foreshadows the welfare state that will emerge after the Second World War.

"The search for balance between freedom and equality is built by dissociation and complementarity between economic and social and finds its expression in the idea of public service linked to the notion of solidarity" (Laville, 2000).

The State as the expression of the general will becomes the custodian of the general interest implemented through the action of administration. The administration gets its legitimacy from the political representation as the company gets its legitimacy from capital. Benefits are only the representatives of the general interest provided from the top down by the State to the citizens The legitimacy of state intervention is limited by social solidarity, but it reinforces its "colonial power" and "its central role in shaping society " Based on law, the state intervention is a pragmatic adaptation of the theories of social cohesion trying to avoid the twin dangers of "individualism" and "collectivism" 
"In this case, the associationist movement which had been the first reaction of the community against disturbances caused by the diffusion of market gradually gives the way to state intervention." (Laville, 2000).

The social question leads to the separation of terms "economic", in its acceptance of market economy, and social, a legal way to protect the society, developed from the division of labour in the two related registers of labor law and social protection.

In this context social work, that had common origins in associationism, will gradually professionalize its intervention. Doing so social work will gradually leave the economic issues which are outside it activities. It has deviated from the social economy project that was focused on emancipation and took on the role of reparation/education of the poor people. This limits social work's action to the specific duties assigned by the state either directly or by delegation of public service. Activities are subject to the differentiation in redistribution of subsidies coming from the state - the so-called "social assistance" and "social insurance" transfers related to work.

The issue of work or non-work becomes the criteria for discrimination and determines the development of the categories of the disaffiliated, the excluded. As long as the welfare state by its regulation of the economy may not be embedded in the other rules of the social game, it ensures its solidarity with the most vulnerable and the poorest, social workers can focus on these populations (disabled people, children at risk, elderly people) to help them to come back to the great game of consumption and do their job with the illusion of an autonomous social field. But, as soon as the first signs of the weakness of the system appear, they will feel helpless in front of the emergence of this new class of the poor, excluded from work, waiting again for the train of progress, but this time without knowing either the platform or the hour... 


\section{The welfare state and the thirty glorious years}

The post-war years until the first oil shock are marked by strong economic growth and, in this virtuous context, this period, described by Jean Fourastier as the "30 glorious years", will see numerous social progresses (labor law, social security, family allowances). The couple State / Market regulated through social dialogue with trade unions installs a majority of French people in the society of mass consumption inspired by the Fordist model.

In this context, social economy organizations take their share in a totally integrated way, developing themselves in this regulated market either in the field of production, consumption and finance where cooperatives and mutual insurance companies adopt a competitive development in a classic way, or in the field of protection and insurance where they complement the action of the State. The social question leads to the separation of the term "economic" from the way it is used in the market. Associations are supported by state subsidies when the activity is related to public service, significantly in the field of culture, popular education, action toward children and the youth, poor families, disabled people and more recently elderly people. In one way or another, the consumers finance insurance, education or social protection, they are finally related to all French citizens who do not really have the feeling that they have to deal with an "other economy". Therefore, all of these organizations that have special status focus on better meeting the needs within the context of a widespread consumer way of life. These organizations finally blend with the rest of the market system in their production of services and way of management.

It is time for the trivialization of the social economy.

This phenomenon of invisibility is the result of a process called institutional isomorphism, it has been theorized and defined as follows: "A cumbersome pro- 
cess that forces units in a population to look like other units that face the same set of environmental conditions" (DiMaggio, 1983; Powell, 1991).

Conclusion: If the Thirty Glorious years gave the feeling of a phase ideal-typical in terms of solidarity, they have also defined this historical period in which western societies have learned to overcome the tragedy of the second world war by engaging in a rush to consumption, which has not stopped since the beginning. The result for the organizations of the social economy has been trivializing their activities in the market system (same middle class customers, same products, same prices, same funding, same management) and a loss of its visibility.

\section{Alternatives Résurgences and neo capitalism}

Prior to the two oil crises and the crisis of the 1980's which has never been completely resolved (to include industrial restructuring, liberalization, globalization, virtualization of the economy, unemployment and increasing social insecurity) French society already knew in the early 60"s as did other economically developed countries, what some have called a silent "cultural" revolution would emerge and did in France with the events of 1968. This probably happened as Montesquieu suggested when institutions are stronger they begin to waver. Might this be the moment of entropy suggested by systems theory? At the same time in 1969 the Club of Rome launched its inaugural "Stop Growth" alert the ecological and critical analysis of the developmental model. This stated in student circles and it spread to the world of workers despite the media is still fairly controlled by the state (ORTF), to the whole of society. For workers, consumers or public services users, the lack of opportunity for involvement as well as the standardized approach from the administration has been criticized. The requirement for a higher "quality" of life appears. The demand for qualitative growth is 
increasingly opposed to the qualitative growth," a lifestyle policy has to be substituted to a standard level of life policy" (Roustang, 1987).

As it is said in the famous song of Bob Dylan: „The time they a changin”. Social movements are expressing new ideas of liberty and equality in the society. Feminism criticizes the absolute power of men in the different areas of social life. Ecologism criticizes the impact of capitalist consumer society on the nature and on the way of life. Users of public services criticize the centralised and standardized decisions of administrations. Citizen's movements begin to criticize politicians and the representative system. Time is coming for social innovations, for a more fair economy and a more participative democracy.

\section{Solidarity Economy}

In this effervescent context the forms of alternative economy will emerge foreshadowing the solidarity economy. Between 1960 and 1982 numbers of associations exploded (from 12.000 to 40.000 ).

The period starting from 1968 to the present year can be divided into three sequences following the periodization proposed by Benoit Levesque (2002).

1968-1975: The awakening of the new cultural movement saw the experimentations and social innovations designed by a new educated class (also mentioned as the new middle class) bringing new values (rejection of mass consumption) and self experiences (refusal of monotonous work, authoritarian forms of management) with them. Social innovations are intended to be in opposition to the dominant model of consumption and mass production; One wants to work in a different way (labor crisis) and/or even to live differently....

It is time to break with the traditional way of fighting, "the order to disperse," the invention of new methods of living in the countryside (neo rural movement), 
the exaltation of local territory, " living "green" and working in the native region", and experimenting with self-managed enterprise and the human sized "small is beautiful".

"If the majority of communities after the May 68 movement meant a probably too radical alternative to live sustainably, they found their continuation in an alternative economy which refers to the creative utopia and claims the possibility of "another way " development based on self-management, solidarity and autonomy". This alternative economy questions all forms of social and economic institutions: the company and its organization, the market, the state." (Levesque, 2001).

This alternative economy has led the way in terms of solidarity savings to investor clubs for an alternative and local management of social savings (Cicada). Foreshadowing the new forms of organizations, it unifies the movement of reciprocal exchange of knowledge and the movement of local exchange systems (SEL), non-monetary exchanges or local currency. One of the major current areas of economic alternative is made by the Network of alternative and solidarity practices (REPAS).

In terms of socio-economic innovations, if the social economy is often the goad of the state and the market, we can also say that the "alternative economy" is often a spur of the "social economy".

The ethos of this "alternative" economy has influenced the historical structures of the social economy (cooperatives, mutual insurance companies, associations) particularly in its third component, the associations. Grouped within the CNLAMCA born in 1970 and under the leadership of critical intellectuals and researchers such as Henri Desroche, these historical entities began to feel the need to reaffirm their fundamental values, the specificity of their collective enterprises. In the $80 \mathrm{~s}$, the CNALCMA offered its members a charter containing intersecting democratic, legal, humanistic and redistributional requirements. The 
following year (1982) with a decree suggested by the politician Michel Rocard (very impressed by the work of Desroche) the Interministerial Delegation for Social Economy DIES (1983) and the. Institute for the development of social economy was created.

However, according to Danièle Desmoustier's conclusions, the CNLAMCA neither met the self-management movement of the 1970s nor directly supported the new social problems engendered by the socio-economic changes (2000). All this tends to give credence to the hypothesis that ALDEA, which was born from a lack of structures of the social economy.

According to Bruno Frere, this gap between solidar economy and social economy is not really ideological. Desroche or ALDEA refers to the same Proudhonist associative origin: it is empirical, just a matter of size. But the evaluation of Danièle Desmoustier is more strict: "The SCOP were powerless to take over bankrupt firms and reintegrate unemployed workers, health and social associations have outsourced the function of youth integration, cooperative banks have left to solidar organizations of financing the responsibility to car and reveal the needs of small-scale projects, agricultural cooperatives have abandoned rural development" "2

In the second period (1975-1985) the innovations were less criticized in terms of the dominant model and as alternative aspirations than from criticism created by the crisis in coordination and control between state and market. There was a break in the virtuous cycle (economic development/social development) through state redistribution and support of demand.

Two streams of social innovation are identified by B. Levesque.

The first was a response to the labor crisis (refusal for monotonous work) and was not as strong as the second, the employment crisis. Social innovations ap-

2 In Frère Bruno, Le nouvel esprit solidaire, Desclée de Brouwer,2009. 
peared in the field of job creation and economic development (implementation of sheltered workshops in the mid-1970's and construction of tools for integration through economic activity starting in 1974).

The second stream: field of social development, housing, services to persons (local social development, neighborhood governed outreach, parental creches ....) more often as a refusal of bureaucratic functioning than to the lack of state initiatives for new social demands.

These social innovations were difficult but fruitful as these experiences took the form of pilot programs and were weakly institutionalized. At the crossroad of these initiatives was a sometime contentious relationship with public administration as the new neighborhood public space is developed whose primary actors will make the claim of its place in the solidarity economy. 1985-2015: Toward a mutual and institutional recognition This phase will be developed in the second part.

\section{Social Economy and Solidarity Economy}

What links, what similarities, shared values, what differences, potential disagreements may we find between the updated social economy exhumed from its foundations by Henri Desroches in 1977 and a solidarity economy reinvented by its actors and conceptualized by Jean Louis Laville and Bernard Eme in 1980? Finally what connections are tempted to be offered between these two components that some call an alternative to the dominant market economy, a new "breath" to the economy controlled by the state? Firstly we must admit that a scientific definition cannot be proposed to unify a set of practices with a common history rooted in mutual and associationist practices of the labor move- 
ments in the 19th century. These practices were relayed, reinforced and most often diverted from their original use by the philanthropic members of the middle class who tried to anchor them in the activities of a third sector, to repair the injustices of the capitalist system, and to compensate the weak intervention of the state. In the idea of François Espagne, inspired by the research of Daniele Desmoustier, the expression of social and solidarity economy would be only a syntagm, covering a range of practices, and searching a paradigm of unified significations. On one hand a set of organizations with specific status (cooperatives, mutual insurance companies and associations) operating in the field of production, consumption and finance for the cooperatives in the insurance, health and social protection for the mutual insurance companies and in the social action, cultural and popular education for the associations. On the other hand a set of citizen initiatives act to democratize the economy, reintroduce values of autonomy of fairness and justice in trade both on a local level (neighbourhood democracy, regies de quartier) and international level (fair trade) with a growing concern for environmental protection and sustainable development (eg organic agriculture and AMAP) If we try to compare these two concepts of economy term by term what will we find?

- A common history found in both based on the values of empowerment and solidarity.

But it is a kind of solidarity that does not take only the cold and mechanical aspect of the system for redistribution of incomes by the state, but a hot, organic solidarity (of the community) expressed day by day among its members by shared values, common conditions and / or common territory in addition a solidarity between generations to preserve the common inheritance of the nature. 
- Common statues, found in both with the association being the most common of the statues and to a lesser extent the cooperative statues.

- A more controversial concern for the collective interest and/or general interest. This distinction is often put forward by the actors of the solidarity economy who focus more on democracy and the general interest in order to differentiate themselves from the social economy, which focuses more directly on the collective interests of its members (ingroup versus outgroup) - Practices to respond to social needs in an alternative way, to the market economy (balance of selfish interests) or state intervention (assistantship). We can find these practices in the origin of the social economy but in fragmentation in different statuses and the institutionalization in the dominant productivist model made this singularity invisible. The solidarity economy criticizes the drift, reactivates this historical dimension of solidarity, renews emphasis to invest the economic field in another way:

- By pooling the contributions of everyone around a common project discussed democratically

-The profit (the product of the activity) is not used to rebuilt capital and the compensation to the members as partners in the cooperative is limited and it is rather used to serve the operations of the activity.

- The business activity serves the general interest (social utility, sustainable development) and used both the internal and external solidarities for either financing (cigales) or working (volunteering).

- Reinventing solidarity on a territory (neighborhood governance, AMAP, local currency) and other forms of non-market exchanges (SEL, knowledge exchange network) 


\section{Looking for a definition}

Are the third sector (between public sector and market), non profit sector, social entrepreneurship different terms to talk about the same thing? Not sure or not completely. There is not a clear and academic definition of social economy, and the concept is the result of a historical construction. However, we can try to give the definition by two consensual criteria: values or principles and statutes of the organization.

\section{Principles / values: Self help and... self-organization}

We understand social and solidarity economy as an economy where associations of people are more important than the capital and the benefits. Social economy is a way to answer our needs which are not satisfied by the classic economy or by public services.

Historically from the very beginning we have seen the values of social economy founded in a non-violent effort to transform the society into a practical utopia of empowering people in their working conditions, social life and citizenship.

In France these values have been written in a charter by the different organizations/members of social economy. Institutions adopted it as The European Social Economy Charter:

\section{The European Social Economy Charter}

Key aspects of the European social economy charter are:

- The primacy of the individual and social objective over capital

- Voluntary and open membership

- Democratic control by the membership

- Combining the interests of members/users and/or the general interest

- Defense and application of the principle of solidarity and responsibility

- Autonomous management and independence from public authorities

- Essential surplus is used to carry out sustainable development objectives

- services of interest to members or of general interest

Brussel 10 April 2002 original version in French 


\section{Statutes of the organizations}

As we said before the social economy sector comprises four families of organizations following the principle of the charter in their operation (except foundations, where the democratic control is not obvious, that is why sometimes this fourth group is not recognized as a member of the family except if it can prove its public utility).

The mutual union model works with the members' funds (in France, more than NHS we all have a mutual insurance for healthcare). Every month you pay a contribution for your mutual insurance, which is paid back to you when you are in need of healthcare. If you cannot pay for a mutual healthcare the government can propose a free one. The funds are the combination of the contribution of all the people who are members although some of them will use it and enjoy its benefits more than the others (by having their health care fees taken care of) while the others who although pay their monthly fee but do not need to use it as they are healthy.

The cooperative model is a free (self) management, with the member's contribution to the social capital which is not negotiable and solvable on the market. The extra money (benefits) is regarded as unshared and inalienable resources, and gives them a strong solidity.

The association model is based on four resources: membership subscription, products solved, public donation and private donation.

The core values of the social and solidarity economy is based on the liberty to join solidarity and equality among the members. The main values are the subscription freedom (every person can be a member of the social and solidarity economy's organization and has the freedom to leave it); a democratic, collective and involved management (All decisions have to be taken in a general assembly. Everyone who has a membership or is currently working in the compa- 
ny is equal, regardless of their job status in the company. In a general assembly the general process is one person $=$ one vote.

There is no profit or the profit is limited (the extra money is reinvested in the social project of the company). Solidarity and responsibility drive every action or project for a sustainable development. The democratic governance assures the living of the group who supports the project and promotes a participative management. This governance takes different forms with the statute (association, SCIC, SCOP, mutual etc).

This economic model is still under construction in our country, and is still not well known by the population and the stakeholders in this sector. To find an official definition of the Social and Solidarity Economy we had to wait for the law of 2014.

\section{The law of 31. July 2014}

In 2012 the French government under François Hollande's Presidency, who previously was the first secretary of the socialist party, nominated a specific minister for "Social and Solidarity Economy". Before that in some previous governments we could find a State Secretary in charge of the Social Economy (1984) and a State Secretary in charge of the Solidarity Economy (2000); however, the two economic systems were not joined under a unique entity. Talking about Solidarity and Social Economy (or fair economy) is quite new at the national level.

In 2012 the nomination of a new minister (Benoit Hamon) was a strong sign of recognition. At national level this sector was officially recognized as a way to develop French economy, social cohesion and employment. On July 31th 2014, 
for the first time a law was voted in France ${ }^{3}$. First, the law admits that no definition has been given to the ESS, and tries to give one for the first time. It gives the outlines and the limits of the social and solidarity economy (and joined both words under one title). This law includes "social company" and social entrepreneur as new actors of this economy. In chapter 1, article 1, the law gives a definition: the social and solidarity economy is a way to begin something, and an alternative economic development in every sector of the human activity, where a moral person adheres to some specific conditions. These conditions are 1: the goals are not only focused on sharing the benefits; 2: democratic governance organized with different levels. Those levels are based on the knowledge and involvement of that person in the organization. The workers are involved in the achievement of the company. The management has to be democratic and based on equality for the decision (and influence).

The social impact for the community is also an important part of this economy. The activities of the social and solidarity economy are production, transformation, distribution and exchange in our community. This law gives a statute to the social and solidarity economy organization, and recognizes it as a way to start something, taking a step forward. It also gives power to the social and solidarity economy network, and gives recognition to them with "the social and solidarity economy Chamber" (which you will find in each "Region" as we call them in France).

In France we have 3 major official levels to promote social and solidarity economy in our territory. We have a National council of the Regional Chambers of the social and solidarity economy (state level - It is an association whose purpose is to help and bring the actors of social and solidarity economy together, to

\footnotetext{
${ }^{3}$ http://www.legifrance.gouv.fr/affichTexte.do?cidTexte=JORFTEXT000029313296\&ca tegorieLien=id
} 
help to gather resources, and to contribute to the national promotion and development), Regional Chambers (associations to gather the networks), and a social and solidarity economy's observatory (network of ESS). This type of institution helps to give a structure and a representation of the social and solidarity economy's sector.

With this law the French government has 5 goals: to give recognition of this economy; to consolidate and support the people who build it; to create a cooperative impact; to give a hand to the regional economy and the local and social development (for example: the local money), and to promote different ways of financing a project.

Meanwhile, it also helps the organizations and the social and solidarity economy network to take shape. Actually it depends on the territories and regions of France. In France we have a functional specificity in regards of each territory. Most of the time, social and solidarity economy concerns social and inclusion sector, sport, culture and art, financial and bank activity (mutual benefits company), education (teaching, training), and agriculture sector.

\section{Social and solidarity economy, Panorama:}

Social and solidarity economy is quite an important sector in France: it is represented by $10.3 \%$ of the work market, and counts about 2.3 million workers ${ }^{4}$ representing 223.000 institutions. It is approximately $12 \%$ of the French GNP.

After 2008 the ESS sector had a bigger contribution to employment: 2\% development (especially in the art sector and care services). In a juridical way the associations are the most representative ones (94\%) of this sector, and they form a sector with the highest employment rate (78.1\%). They are followed by the cooperative

$4 \quad$ Number from 2011 
(13.2\% of the employment), the union-mutual fund- sector $(5.6 \%)$ and the foundations with $3.1 \%$ of employment. In this sector $76.6 \%$ of the companies are microcompanies (1-10 workers). In France approximately 66.000 associations are established every year, however, the social and solidarity economy's sector is more or less developing in the different regions of the country.

Solidarity economy also means new modes of solidarity financing: in 2014 crowd-funding collected 150 million Euros.

Voluntary work is also a big resource: it represents about 11 to 14 million people who are members of different associations (but the number of volunteers is still the subject of polemics). It represents around 1.3 and 1.5 billion hours of volunteering work, mostly in the sport sector, leisure activity and culture. The volunteers are not only represented by retired people, but it is also a big portion of the working population (between 35 and 49-year-old people).

The work in social and solidarity economy's sector $(10.3 \%$ of all employment in France and $13.8 \%$ of the private sector) means part-time work most of the time. Part time job is explained by the type of work contract: the ESS sector especially uses "integration-contract" ("contrats-aidés"). It is also due to the work sector: for example the care services employ a lot of workers in part-time jobs. Contracts that have a specific time are also more important (CDD - fixed term contract) in this sector.

The workers in the social and solidarity economy's sector are more qualified than in the private sector; women are over represented (67\% of the workers in the social and solidarity economy's sector are women). This strong gender specificity is due to the social and solidarity economy activities mostly in health care services, social work and care in general. In this economical form the salary seems to be less important than in the other economic sector: in 2009 workers earned $16 \%$ less than in the private sector and $7 \%$ less than in the public employment (for a full 
time job). $8.6 \%$ of the employees in the social and solidarity economy's sector are under 30 years old (that represents 435.490 person $^{5}$ ). Managers (47.2\% of them) think that young people are more sensitive to the social and solidarity values. These values and commitments support training courses for workers: they really care about the work quality and the well-being of the workers in regards of the achievement of work. The social and solidarity values are very important in this type of economy and mean a big contribution to the innovation.

Solidarity values encourage local activity (such as local consummation), sustainable development (companies try to encourage non-pollution and recycling), and community initiatives. For example in the agriculture sector farmers create a cooperative for rental machines $-C U M A$-, or Regional politics impulse the "PTCE"-Pole Territoriaux de Cooperation Economique - Economic pole of cooperation by territory - which is an economic union with a territorial strategy. It is a kind of economic partnership for sustainable development and local innovation. The members put competences and knowledge together to become stronger in an economic level.

The first sector of social and solidarity economy is formed by social work and social services with $62 \%$ of employment. In France the care and support of social institutions depend on the public State, even when it is under an associative model. It concerns the care and support of people with disabilities, care and support of children and teenagers with challenging behaviors (institution, fostering family), care and support of homeless people, support for access to work, care workers.

Social and solidarity economy's actors would like to change and have an influence on our community and society. The idea is to move on general interest and to try to transform the system production and social cohesion. This economic system has many stakes: a way for our public government to be disengaged and to give more

$5 \quad$ INSEE, 2013 
power to private charities; to hide benefits behind social values; or in a most positive sense: to understand our need for change and the need for evolution.

\section{Issues and challenges}

After 2008 (and the financial crisis) it can also be regarded as a contribution to develop innovations in a crisis context and to meet more needs from less financial resources. France, as well as others European countries, had less public money distributed to the public sector. The actual context is pushing communities to build new solutions together (resource hybridization). The law can be understood in two ways: the primacy of social company and its status considering that the purpose is to give benefits to all; or focusing on groups. In this case the purpose is how we distribute the power and how we take decisions. The social and solidarity economic issues are to develop the local economy (proximal economy) to bring more territorial equality and to develop the circular economy (the impact on how we consume) and the functional economy (ESS is an economic organization that tries to provide responses to society attempts and transformation needs in environmental, social, educational and political areas).

The point is to have a better economy and a firm belief that economy can be respectful of our moral values (so "social"). Social and solidarity economy is like a tool for social cohesion it is also a way to stimulate social cohesion (in institution, organization) and community. Social cohesion means the inclusion of all in the society: "circuits-courts" (short circuit: buy products close to your place, local and respectful consumption) and "finance solidaire" (fair finances: it is when several people join to finance a project -with a social and fair purpose).

But one of our limits is the non evaluation of these contributions to the social cohesion. Another limit is the segmentation: in some activities (as inclusion) public 
is specific and they are locked in some social measures. It can be observed that the cooperation is not natural and supposes institutional mediation to support social cohesion where junction between public action and all local actors is needed.

\section{Main trends: Example of French citizen networks and main institution:}

In France we see some citizen networks appearing: they are the heart of the ESS. For the moment, the most popular link between ESS and the (middle class) population is the alimentation market. The AMAP network (Association de Maintien pour l'Agriculture Paysanne-Association for the Upholding Farmer Cultivation) is developing with "organic basket". One example of this is a social cohesion stimulator between a local farmer and the people in the community. The farmer distributes an "organic basket" every week to one, two or four people (the cost is usually between 10 and 20 Euros). In this business transaction there is a direct producer to consumer relationship with no middlemen. Typically the consumers have a commitment to the farmer for 6 to 12 months.

On the other hand we are having a network in France called "La Ruche qui dit oui" (700 hundred all over the country). "Les Ruches" (=hive) are "intermediary" (called "service provider" by the network) between the local producer (less than $250 \mathrm{~km}$ from the hive) and the consumer. It is a social company statute. The main difference with AMAP network is that you can choose your product online; you have a list of what you want and you can go and pick them up in the "hive". At the spot you can meet the producer most of the time. In this system producers can choose and fix their prices. The producer pays to join it because the network is working with workers ("hive manager" who organizes sales process and the organization, "mummy hive" who works on the website and supports the development). The "customer" is called "member". A debate exists 
between the AMAP and the "Ruches": AMAP accuses "les ruches" to make benefits and profits as a social company and puts pressure on the producer for being a member; in fact it reproduces the classic economical system.

$A N D E S$ : the network of social groceries is one of the main networks to provide food aid. The association was created in 2000 by Guillaume Bapss. Social and solidarity stores are local convenience stores where people with low income can buy everyday goods for about 10 or $20 \%$ of their "regular retailing price". This form of food aid was created in France in the 1980s, as an addition to a system of free distribution essentially to the homeless or the very poor people.

Instead, solidarity stores are for people with low income (working poor, unemployed, retirees with a low pension etc.) who cannot afford buying food in "normal" supermarkets but who are, on the other hand, reluctant to benefit from charity. In France, social stores are usually run by associations working in close relations with local social services. They together review applications and decide the length of the period while the beneficiaries can have access to the store. On average, people go to these stores for a period of 2 or 3 months, but that can be extended up to 6 months or even a year, depending on their situations.

These stores are supported by local authorities, by organizations like the Food Bank and the Red Cross, by foundations and by private companies through local or national partnerships. The difference between social and solidarity stores is that social stores are responsible for one or several towns and they are publicfunded, while solidarity stores are launched by individuals or associations grouped together and they are cross-funded. There are 500 social and solidarity stores in France. They represent 1200-17.000 “clients" per year. On average, a social store feeds 100 households per year. In 2011 A.N.D.E.S. received about 101.7 tons of products containing dairy products, seafood, and other products from its partners (Ferrero, Danone, Yoplait, Paniers de la Mer), to be distributed 
in solidarity stores through the professional integration of workshops in Rungis, Perpignan, Marseille and Lille. With this example we can note how social and solidarity economy can deal with the market (and the liberal economy).

CNLRQ Network of neighborhood governance (Régie de quartier), kind of "community work"

In our territory approximately 140 "neighborhood governance" can be found, on 320 "priority areas" all over the country. This network represents around 7500 workers. They work with public collectivities and social housing companies in local projects. The activity of this network (which is a community association) is a joint social activity for economic inclusion and "popular education". The governance of the neighborhood brought neighbors and people having difficulty to engage in a common project for the area. The people who live in the area will be responsible for their own environment. They work for social, economic and politic dimensions to provide real citizen position to people with insecure situation. This network is engaged for creating animation on the priority area, giving representation to this movement for developing the network. Solidarity economy mixes human resource and economic resource to support inclusion. They are the founder members of AERDQ (European Association of neighborhood governance).

COORACE was created 25 years ago by a group of unemployed people. This citizen initiative is a national network of 500 enterprises for social inclusion by economic activities IAE. With 18 regional groups this organization contributes to the evolution of labor market. It tries to avoid segmentation, tries to put some pressure on the institutions and ministries to get better laws and regulations in the labor market system and tries to provide training services. There has been a long period where the main goal was to have a kind of waiting chamber (second market) where the unemployed with social difficulties were prepared through specific measures to adapt and then to enter the classic labor market. The new 
orientation, inspired by the social and solidarity values tries, in a local development perspective, to create sustainable activities and employment. A lot of organizations and social enterprises are cooperatives where workers in the integration process can become members.

$I M P A C T$ is an umbrella organization, a network of 10 different networks in the agriculture sector (Terre de liens, CIVAM, ARDEAR, CBD, AGRObio, Solidarité Paysans....). Each network is working in a specific field but they can meet common orientations or goals by promoting a sustainable development of agriculture, in respect with biodiversity with organics methods far from industrial model, by helping young farmers to set and develop their activities and avoid financial difficulties, by providing research and training services;

Colibri movement: this movement emerged from the idea of Pierre Rhabi, a philosopher in 2007 with the aim of working on the building of a more human and ecological society. This association is a citizen network. It tries to inspire, connect and support the citizens in transition process. They organize local meetings, publish books and document local experiences (in education, agriculture, accommodation etc.). The aim is to share skills and expertise. Nowadays they represent 55 citizens groups and they propose initiatives like a cooperative and pedagogic school in Dordogne, local money ("stucks") in Strasbourg, a "seed-place" in Aubagne, urban vegetable garden in La Ciotat etc. They perform several territory animations. They actually work at Colibri university (in creation) and they are still working on an oasis project to create new ecological and participative space in less than five years (some have already been existing).

Cigales (= cricket): This movement emerged from the social and solidarity economy in the 1980s. The goal of this citizen movement (called ant) is to get contribution from everyone to realize a project. It is a human and financial support with providing advice for the first year of the project or the company. 
Cigale's clubs are built in a structure with a solidarity capital which mobilizes members' saving to create and develop small and local companies. A club usually has 5-20 members who put their savings together. The monthly saving is around 25 Euros per member. In 2013 there were 233 active clubs and 3104 „crickets” (which is twice as many as in 2008. This represents 95 projects and an investment of 430.000 Euros.

France also has some representative institutions in terms of the social and solidarity economy for example the Godin Institute, which is a center of practical research in social innovation that was created in 2007.

\section{Research}

The sector of social and solidarity economy is still "new" and we have very few official analyses or research on it. Regional's Chambers are in charge to provide national diagnoses, and since 2014 departmental diagnosis as well. In France one of the most famous and popular journal on economy is "Alternative Economie" where the general public can read about social and solidarity economy.

The most influential researcher worker is Jean-Louis Laville. He is a teacher of economy and a sociologist in CNAM, Paris. He is a member of the European network EMES and it was him who introduced the term solidarity economy in the 1980's. He is a collection director in Brasil, Italy and France. Nadine RichezBattesti, is a senior lecturer in economic sciences at Aix-Marseille University. She is a member of some research networks and she is at the redaction committee of the RECMA (International Revue of Social Economy). She works on social innovations, governance in ESS, connecting ESS with territorial and employment quality. Also, Danièle Demoustier, a senior lecturer in economic sciences in Politics Institute in Grenoble. She manages an association and a cooperative team 
(ESEAC) and is a member of the Superior Council of Social and Solidarity Economy. She works on the ESS contribution at the territorial development level and on the social and economic regulations. Jean-François Draperi is a doctor of geography (Panthéon Sorbonne, Paris University) and a senior lecturer in sociology (CNAM Paris) where he manages the social economy center. He is also the head redactor of RECMA. Most of the research is in two areas - an association for development and information on social economy (Addes) and in Inter-university network of social and solidarity economy (RIUESS).

\section{To not conclude}

All of those research workers are influential in the social and solidarity economy sector in France at a scientific level, but in research it is very difficult to focus solely on social and solidarity economy. The general public does not really know about what social and solidarity economy is, and how it works, they do not even know if they are involved in or not. Why? How? We cannot give all the answers here, but we can propose some hypotheses: first, the main/major media does not talk about ESS; it is quite difficult and simplistic to oppose private fields and ESS fields. In fact most of the time, being an actor in ESS implies a political commitment. But the social and solidarity economy is not a political movement and it is not really (or not yet) a structured social movement. Maybe this nebula of initiatives is forming a new direction; a new shape committed less to institutionalization and more to pragmatics and distancing itself from ideology.

Private sector production is not useless for our society, it is rather a matter of how to create and produce in a good, reasonable and sustainable manner, however, many people do not feel concerned about it and prefer the results and the diversity of products. We have to take in consideration that the production of the 
ESS is limited and the alternatives are still limited. The social and solidarity economy sometimes served as a "second hand" for the public services and some associations (especially in the social work), which reproduced contradiction: support and help people in need in an assisted way rather than to find a way of empowerment. To make a distinction between ESS (which is in the economy market) and general economy is not easy. In France the fields of the social and solidarity economy are not organized and unified in their position, form, practices and goals. It means serious difficulty for this sector developing unified alternative projects. There are many projects and several small solutions but the difficulty is to pass from micro level to macro-level. How can we have a participative governance in a company of 500 workers? How to answer to hundreds of consumers when you are a local farmer? This will be a new challenge if we want to build strong alternatives while taking growing and changing needs from consumers into consideration. In France the organic / alternative market is increasing. Many people criticize it as luxurious consumption and care. Our hope is: we are on the right track to change our consumption behavior. This trend is starting to become effective in neighborhood actions for instance some social groceries are provided by organic vegetables produced by some social enterprises. Recycling workshops are developing and a part of the new generation is involved in solidarity initiatives. As usual change is coming from the edge of society, from the margins, like on the written page criticisms are visible in the margins where ethics meet needs. This way of thinking about social economy, not as an economy of social services in a liberal economic context but as a renewal of the way of thinking Solidarity and Citizenship, may be partly utopian but we need it. As Henri Desroche wrote it ${ }^{6}$, for realizing big things it is not enough to act, it is necessary to dream...

6 Desroche Henri, Sociologie de l'espérance, Calman Levy, 1973 


\section{References}

Artis, A., Demoustier, D., \& Puissant, E. (2009): Le rôle de l'économie sociale et solidaire dans les territoires:, six études de cas comparées, RECMA N³14

Dacheux, E., \& Goujon, D. (2011): Principe d'économie solidaire, Ellipses

Desroche, H. (1973): Sociologie de l'espérance, Calman Levy

Eme, B. (2005): Gouvernance territoriale et mouvements d'économie sociale, RECMA N²96

Enjolras, B. (2005): Economie sociale et solidaire et régimes de gouvernance, RECMA N²96

Frémeaux, P. (2014): La nouvelle alternative? Enquête sur l'économie sociale et solidaire, Les petits matins

Frère, B. (2009): Le nouvel esprit solidaire, Desclée de Brouwer

Laville, J-L. (2013): L'économie solidaire: une perspective internationale, Pluriel

Laville, J-L., \& Sainsaulieu, R. (2013): L'association: organisation et économie, Pluriel

Levesque, B. (2001): " les entreprises d'économie sociale plus porteuses d'innovation sociale que les autres», communication colloque ACFAS Mai

Observatoire National de l'ESS, CNCRES (2014): Atlas commenté de l'économie sociale et solidaire 2014, Broché, 2014, 224p. 
Websites:

http://www.lelabo-ess.org/

www.colibris-lemouvement.org

http://www.inpactpc.org/

http://www.coorace.org/ 


\section{Social Economy and Social Work in Austria}

Gerhard Melinz, Astrid Pennerstorfer, Brigitta Zierer

This article aims at discussing the societal rootedness and the meaning of the term social economy in Austria. To reflect the welfare system as well as social services in Austria it is necessary to define the term Social Economy. Applying the EU terminology of Social Economy, which distinguishes four subgroups, we examine the legal conditions for Austrian social economy organizations with a special focus on social enterprises. The article also discusses the relation between social work and social economy and presents the development and the transformation processes of the Austrian public-private welfare mix. Finally, we determine the size of the Austrian social economy and discuss the funding structure of the sector.

\section{The terminology Social Economy in Austria}

There is no clear evidence when the term social economy was used for the first time in the context of social work in Austria. In 2004 the Austrian social economy thematic group was established within the EQUAL-programme in order to re-launch a public debate in Austria on the issue of social economy and the reform of social services. The Social Economy Conference in Vienna in January 2005 was a first landmark event in this development (see documentation 2005). It was organized by the „Social economy network Austria“, an outcome of 14 EQUAL-development partnerships, which were founded and financed by the EU-programme EQUAL. 
In the run-up to the conference, which - according to the press - was primarily intended to promote the public image of social economy organizations and their social value, the journal Kurswechsel published a special issue entitled "Social Economy in Austria - Alternative or Stopgap" (Kurswechsel 2004 Issue 4). The debate therein made sufficiently clear that the term "Social Economy" was not firmly established in society. Instead, different concepts were promoted such as the term "Non-Profit Sector" following the definition of the Johns-HopkinsProject or "For-Social-Profit", thus emphasising the aspect of social benefit (Social Economy 2004: 7-16). A definition of Social Economy which is unanimously accepted by the global scientific community does not exist, nor is it possible. If Social Economy is discussed within the context of Social Work, the transformation process of the Austrian welfare state - especially changes in the public-private welfare mix - should receive particular attention.

In 2005 the Social Economy Network Austria (Netzwerk Sozialwirtschaft Österreich) was forced to discontinue its activities. On the one hand the Vienna Economic Chamber did no longer support the network, even the voluntary sector did not find a common strategy. Former head of the network Veronika Litschel claimed that this was largely due to the "five large welfare organizations", which had their "own communication channels to [the] government" and therefore "saw no advantage in opening up the field to other social economy organizations" (http://www.wikipreneurship.eu/index.php/Social_economy_network_Austria 2015-09-05).

Finally in 2012, the Association of Employers for Health and Social Professions (BAGS), which had existed since 1997, was renamed to Social Economy Austria (http://www.bags-kv.at/1058,,2.html).

Far from being a household name among social workers it seems that meanwhile the term social economy has become more widely spread inside the social sector - 
at least to some extent. However, its public presence can be considered only marginal at best. News coverage of the current refugee situation has demonstrated that organizations such as the Red Cross, Caritas or Diakonie are commonly referred to as charitable organizations. In August 2015 the Mayor of the City of Vienna applied the term NGO to all the organizations involved in activities for refugees.

With regard to questions relating to the terms Third Sector, Non-Profit Organization, Non-Governmental Organization, Social-Profit Organization, Social Economy, Social Services, Non-Statutory Welfare Agencies and Social General Interest Services the two Austrian researchers Nikolaus Dimmel und Tom Schmid (2013) suggest:

If organizations from the "Third Sector" provide social services, they can approximately be identified as Non-Profit Organizations because they do not generate a commercial profit, and they can definitely be identified as Social-Profit Organizations since they produce specific "social profit" through the prevention of social costs. Social services empower their clients (users, customers); they solve social problems, relieve social (sub-)systems, normalise social relationships and reduce the social costs of (primarily) profit-oriented economic decisions (See Dimmel, Schmid 2013: 14).

This definition implicitly reflects the affinity between social economy and social work - even though the term "Social Economy" is not an explicit part of it.

\section{Legal definitions and conditions for social economy and social enterprises}

Neither "social economy" nor "social enterprise status" are afforded legal recognition in Austria or in other EU member states. In the context of Social Economy 
and the delivery of social services of general interest the European Union defines four major groups: cooperatives, mutual societies, foundations and associations.

\section{Associations and Limited Liability Companies}

The legal form association (see Austrian Association Act 2002) represents the majority of the organizations within the social sector. The greater number of organizations in the social sector or social economy are associations pursuing public benefit goals, which have to be laid down in their statutes and articles, so that the respective tax advantages (see Austrian Federal Fiscal Code, $\S$ 34-47, BGBl. I Nr. 118/2015) can be granted. The complex legal conditions cause considerable difficulty for associations, which in the face of recent financial and commercial challenges have to act flexibly and dynamically. In the past decade an increasing number of organizations (organized as "public benefit associations") have divided their field of business into two parts: on the one hand they continue acting as traditional associations and on the other hand they assume the legal form of a private limited company, commonly known as not-for-profit limited liability company.

An interesting study on the strategic and legal motives of leaders of such organizations demonstrates the ambivalence between the Austrian legal regulation system and the taxation rules (Stichelberger, 2012). Representatives of nonprofit organizations (social economy enterprises) are missing legal rules which would meet their needs more closely than they do now.

In 1997 NPOs criticised that a new postal law was adopted which massively increased the tariffs for distributing journals and magazines of these organizations. Consequently, NPOs from different areas started to cooperate in order to advocate a common interest. In 1998 they established a common interest group (IÖGV) - now IGO (Interestgroup for Non-Profit Organizations - 
Interessensvertretung Gemeinnütziger Organisationen). In 2001 IGO in cooperation with other umbrella organizations developed the „Austrian Seal of Approval for Donations“ (Spendengütesiegel). The Austrian Association Act of 2002 posed further challenges to the platform as it contained very specific regulations for fees and the taxation of associations (NPOs). IGO took a big step forward in 2009 when it succeeded in implementing taxdeductibility for donations in favour of organizations which are committed to e.g. charity or development cooperation activities. 18 percent of all taxpayers (more than 700,000 Austrian citizens) made use of this legal opportunity (see Fundraising Verband Austria 2014). In 2012 IGO successfully promoted a reduction, and in some cases even a cancellation of banking charges for NPOs (http://en.gemeinnuetzig.at/historyachievements - [2015-09-01]).

\section{Foundations}

Foundations make up another major group included in the definition of social economy within the European Union. Austrian law (for a comparative overview including the Country Report Austria see European Foundation Centre 2011) distinguishes between two types of foundations:

- The Foundation and Funds Act (Stiftungs- und Fondsgesetz) of 1974 followed by nine additional state acts formed the basis for federal and provincial public benefit foundations, which are required to pursue public benefit purposes.

- In 1993 the Law for Private Foundations (Privatstiftungsgesetz, BGBl. $\mathrm{Nr}$ 69/1993) was introduced, which enabled the establishment of foundations pursuing both private interests and/or public benefit. The new law granted tax advantages even for those serving private interests only. 
Meanwhile, these regulations have been modified. In Austria charitable foundations enjoy the same tax advantages (with regard to the Austrian Tax Code, Bundesabgabenordnung - BAO) as other charitable organizations taking different legal forms. As for any other legal entity or individual, donations from foundations to organizations which are listed as a certified charitable organization by the financial authorities qualify the donor for tax breaks. The limit is 10 percent of its or her/his annual income. A current study argues in its concluding remarks that the law for private foundations ,, did not intend to foster private contributions for the public good. Furthermore, the existing philantropical legal forms in the foundations sector did not gain any significant importance during this time period, neither as an instrument for private philanthropy, nor as an organisational form in the Austrian nonprofit sector." (Schneider/Millner/Meyer 2015: 45).

To sum up, foundations only play a minor role in the Austrian social economy.

\section{Cooperatives}

Although there are various legal regulations pertaining to cooperatives in Austria, this legal form does not generally play an important role in the social service sector (as is probably the case in Italy).

The first law was enacted in 1873 and it had several amendments. In 2006 the Cooperative Law Amendment Act changed the law on cooperatives (Federal Law Gazette BGB1 I Nr. 104/2006). It was followed in 2008 by the Corporate Law Amendment Act, which changed the corporate law (BGB1. I Nr. 70/2008) to the 
effect that cooperatives were authorised to pursue also social aims (which they had previously been able to do only implicitly).

Additionally, the European Cooperative Society (SCE) Regulation of 2003 was already implemented in the Austrian Law of 2006. However, in December 2009 SCEs did not exist in Austria, because there was ,a lack of necessity for use of cooperatives in cross-border activities“" (Roessl/Reiner, 2010: 325).

\section{Mutualities}

The fourth subgroup of social economy organizations comprises mutualities, an organizational form particularly relevant in France. Mutualities per se are very rare in Austria, and practically non-existent in the Austrian social economy.

\section{The Influence of the European Union}

In 1997 the European Commission published its Communication "Promoting the Role of Voluntary Organisations and Foundations in Europe" [(Com(1997) 241]. By supporting voluntary organizations and foundations it intended to promote the dialogue among European citizens and provide information on social policy developments and measures to combat social exclusion and discrimination. The concept of a structured civil dialogue dates back to the Maastricht Treaty (1992), which includes Declaration 23 (Declaration on Cooperation with Charitable Associations) annexed to the EU Treaty. This declaration puts special emphasis on the cooperation of the European Union with charitable organizations and foundations acting as institutions responsible for social welfare establishments and services. 
Most recently, in the wake of the Social Business Initiative of the European Union (October 2011), social enterprises have increasingly been attracting interest also in Austria. In the context of the economic crisis they have been attributed the ability to find innovative ways to promote social cohesion and inclusion, employment, growth and active citizen participation. Social business has been considered to have a positive effect on society, the community and the environment.

The European Commission intended to contribute to the creation of an environment favourable to the development of social business in Europe (see also European Commission 2012, Entrepreneurship 2020 Action Plan 2012) and of social economy in general, but it has not yet legally defined social enterprises. However, social enterprises should at least meet the following three criteria:

- a clear social aim

- an entrepreneurial approach, which should distinguish social enterprises from traditional non-profit organizations or social economy entities through a form of self-financing

- a governance dimension including organizational autonomy, participation and inclusive orientation (European Commission 2014a: 2)

Most notably, the Single Market Act II (2012) included a series of measures aimed at the service industry as a sector showing significant growth potential. Subsequently, in 2013 the European Social Entrepreneurship Fund Regulation $N r$. 346/2013 was issued, which provided a new label facilitating investment in social enterprises.

Neither the European Commission nor the Austrian government have yet created a legal definition of social enterprises. Even the Country Report Austria (2014) financed by the European Commission and prepared by a group of experts criticised that Austria is the only member state which is not represented in the 
GECES-group (Groupe d'Experts de la Commission sur 1'Entrepreneuriat Social). Furthermore, Austrian policy makers still tend to see social enterprises only as a way to foster the integration of persons into the labour market. In other words: ,, Work Integration Social Enterprises (WISE) are the only instutionalized form of social enterprises existing in Austria" (European Commission, Country Report 2014: 3).

Economic players have recently begun to acknowledge social economy as a category. According to the EU social economy organizations have in common that the focus and purpose of their activities is not to make profits for the financial gain of their owners. Social economy organizations aim at the delivery of goods and services (including employment opportunities) for their members or the community as well as they pursue goals of general interest (i.e. activities which society at large can benefit from such as the delivery of social services of general interest, SSGIs).

All in all, it has to be mentioned that the entire social sector has greatly been influenced by EU directives and their legal consequences:

- the EU Services Directive of December 2006 and its Austrian version (one federal law and nine state laws), which did not favour NPOs in the social sector and

- the duty to carry out tendering and procurement procedures (Federal Public Procurement Law 2006 and Amendment 2013, BGB1. I, Nr. 128/2013). 


\section{Political and legal conditions for social economy and social work}

The Transformation Process of the Public-Private Welfare Mix (Austerity Policy, New Public Management)

The umbrella term "Social Economy" has a long history in Austria. Form, size and significance of the four major groups - cooperatives, mutualities, foundations and associations - differ considerably from organizations in other countries, as the CIRIEC study from 2012 clearly shows - even though there is some room for improvement in data quality (Monzon/Chavez, 2012). If we focus our attention on social work in Austria, especially associations, not-for-profit limited liability companies and foundations with a general interest orientation are to be considered relevant.

As already mentioned, the term Social Economy has hardly been used in the field of social work. In the literature claims have been made that the introduction of New Public Management strategies at a politicial and administrative level has produced negative effects on professional social work and associated institutions and organizations. The implementation of New Public Management strategies in the public administration of Austria (federal state, provinces and cities with their own statute) can be shown to have started already at the end of the 1990s, whereas its lasting effects on social services occurred only after 2000.

Development and expansion of social services and the simultaneous growth of social economy organizations can be attributed to the following legal innovations:

- In the first half of the 1970s "social services" were reregulated by the (nine) Social Assistance Laws, which enabled the development of new supply structures as much as

- the new Federal Acts of Youth Welfare (1989) of the nine provinces did. 
- Since then the provinces and cities with their own statute have been able to provide new services in the context of the private sector administration of public authorities as well as entrust private organizations in the social sector and their facilities with the delivery of statutory personal social services.

In the mid-1980s financial and social policymakers agreed that further expansion of social services at the expense of the provincial and municipal administration had to be stopped (see Melinz, 2003).

New organizations in the social sector

With regard to funding and organizational structure professional social work in Austria has historically mainly been the responsibility of the Federal States and municipalities. In social work an innovative development process started at the beginning of the 1970s that created a number of new fields of action for social work, including new organizations (social welfare organizations of the social economy sector) in the 1980s. It was a real challenge to develop and stabilize such organizations. One important stimulus in creating new options for care services came in the wake of the Austrian Federal Care Allowance Act (BGLBl No 110/1993) in 1993.

Already the 1960s saw the establishment of - now large - organizations for specific target groups, which today can be referred to as social economy organizations and are active in various business areas, e.g.

-In1965 the Austria-wide active association Pro Mente Infirmis was founded to provide services for people with mental disorders in the fields of housing, work and leisure as well as support for self-help. As an umbrella organization of 26 organizations Pro mente Austria supports more than 50,000 people in Austria, advises 3,100 employees and accompanies and supports people with mental 
health and social problems in the following areas: employment, education, volunteering, empowerment, forensics, leisure time, help for relatives, adolescents, crisis services, mobile care, prevention, psychosocial counseling, rehabilitation, addiction, day structure and housing. (see http://www.promenteaustria.at/index.php/home[2015-09-21])

-In 1967 the association Lebenshilfe Austria was established to represent the rights and interests of disabled people. Lebenshilfe provides nationwide services for people with disabilities in the following areas: residential (apartment buildings, assisted living, etc.), work (workshops, day-care centers, etc.), kindergartens, early childhood intervention, services (counseling, assistance, support, employment assistance), shops etc.

Both organizations have greatly expanded their areas of activity and can be called social economy organizations also employing social workers.

The 1970s and 1980s: Social Workers as Social Managers or Social Entrepreneurs

In the 1970s - in the context of the newly created "Social Services" in the area of (nine) Federal Social Assistance Laws social workers started initiatives of social projects and enterprises - e.g. for homeless people. The 1970s and 1980s were characterized by a spirit of optimism and by numerous social initiatives, projects and the establishment of new associations. Social workers often identified the specific needs of their client groups and succeeded with their commitment in convincing people with political responsibility of the need for new offers. The concepts of these new projects were consistently low-threshold and participatory-oriented and characterized by partiality towards clients (the users of the individual offers). 
After that many of these pioneers led these organizations and often had to face the challenge of their (often deliberately chosen) dual function of consulting and management. Criticism of the self -chosen leadership role from their own professional group was answered with strong commitment to a democraticcollectivist-oriented participatory leadership style, because up to that time only special departments were led by social workers (for example Youth Welfare Offices). Organizations in the social sector that employed social workers were mostly led by non-specialists (e.g. lawyers, psychologists, economists).

The following are some examples of social initiatives created by Austrian social workers or social work students:

-In 1978 the Verein Wiener Frauenhäuser - Vienna Women's Shelters Association was established. That same year the first Vienna Women's Shelter was opened on the initiative of students of the former Academy of Social work with the help of committed politicians like Johanna Dohnal or Irmtraut Karlsson. In 1988 the association Austrian Women's Shelters Network was established as a network of 30 autonomous women's shelters in Austria. In the 1970s social workers founded a day center "Club for the Homeless" for the homeless in Vienna. In 1979 the association Working Group for the Non Sedentary Vienna (ARGE Wien) was founded. The 1980s saw the first employment projects for the homeless including the construction of a permanent second hand shop in the $16^{\text {th }}$ district. In the $1990 \mathrm{~s}$ additional residential housing was also built. (see http://www.argewien.at/verein/ueberuns/geschichte.html [2015-09-21])

In 1981 the association Durchgangsort für Wohnungs-und Arbeitssuchende DOWAS - (The place for housing and job seekers) was established for homeless people in Bregenz. In the mid-1980s the offer was extended to include assisted living. It was a network of social and youth workers, citizens, social organizations, politicians and administration. DOWAS now provides housing for 
those searching for apartments, a job project for job seekers (which was merged into the non-profit LLC integravorarlberg), support services for securing a livelihood, a communications center ("Treffpunkt" -"Meetingpoint"), an emergency shelter, a counseling center, external care based assisted living apartments, etc. (see http://www.dowas.at/customdata/uploads/2011/11/30Jahre-DOWAS Zeitung 2011-09_ARIAL1.pdf and http://www.dowas.at/wirueber-uns-der-verein-dowas/ [2015-09-21])

- In 1982 the Emmausgemeinschaft St. Pölten - Emmaus St Pölten was created by a social worker as a safety net for ex-convicts. The Emmaus Community now offers services for people in crisis situations in the areas of housing, employment and social integration. (see https://www.emmaus.at/ueberemmaus/organisation/ [2015-09-22])

- In 1988 the first Schuldnerberatungsstelle - Debt Counseling Center of Vienna, today transformed into a nationally certified non-profit counseling center funded by the Social Fund of Vienna, the Public Employment Service and the City of Vienna, was founded on the initiative of a social worker.

The influence of "Action 8000" (experimental labor market policies) in the 1980s on new social economy organizations

Numerous social initiatives of the 1980s go back to the so-called "Action 8000" created by the Social Minister at that time, Alfred Dallinger. Due to increased unemployment figures he set up new labor market policy measures to support long-term unemployed people to re-enter the labor market from 1981 onwards. Since increased personnel placement services and mobility grants were no longer sufficient to ensure full employment, differentiated job creation measures were developed. One focus was on the creation of temporary jobs for the long- 
term unemployed in existing non-profit organizations ("Action 8000") as well as in newly established enterprises - the first socio-economic enterprises (SÖB)-and non-profit employment projects (GBP).

Parallel to the creation of job, courses and labor market policy oriented advice and care facilities were created to improve the placement and performance of the long-term unemployed and improve qualifications and help them to solve social problems that could make it difficult to start a new job. As of 03/31/1991 there were 231 projects of "Action 8000", 56 socioeconomic employment projects, 59 project-oriented social courses and 98 labor market policy advice and support projects. (see Biffl, 1994. 3)

In the years 1980-1988 a total of 60 Sozialökonomische Betriebe -Socioeconomic enterprises (SÖB) were created in Austria. As labor market policy instruments the SBÖs were, due to their nature as companies and the economic requirements specified by the employment office (share of own earnings), interwoven with labor market success criteria (qualification and personnel placement). These operational and economic elements were mainly associated with the expectation of creating situations as close as possible to real work situations. (see Lechner et al, 2000: 3). In 1983, for example, the labour market policy advisory institution - Counselling Center for Migrants (formerly: Verein zur Betreuung von Ausländern - Association for the Care of Foreigners), was established. In 1993 the counseling center was expanded to include an institution for women. In 2004 agendas of the Vienna Integration Fund were taken over. The counseling center offers not only labor market consulting but also various counseling services for newly arrived migrants including issues such as recognition of professional qualifications etc. 
From 1984 to 2007 the association der Würfel - the Cube - offered a lowthreshold advisory service for innovative employment and the unemployed, a counseling café, a second-hand shop, a bookstore, a creative workshop and an employment project.

(see http://www.derwuerfel.selfip.org/geschichte.php [2015-09-23])

From 1990: Civil society participation, international networks and the EU Services Directive

In 1995 the Österreichische Armutskonferenz - Austrian Poverty

Conference was established as a network of over 40 social organizations, educational and research institutions in order to work on the backgrounds, causes, facts and figures, strategies and measures against poverty and social exclusion in Austria. In 1995 the first Austria-wide poverty conference took place. This Conference is a member of the European Anti-Poverty Network (EAPN) founded in 1990. Numerous Austrian social economy organizations are members of the EAPN: e.g. the action group of autonomous Austrian Women's Shelters, Workers' Samaritan Federation Austria, Caritas Austria, Volkshilfe Austria, Wiener Hilfswerk.

The international networking of numerous agents in the context of EAPN and Austria's EU accession in 1995 led to stronger international networking especially within the European Union.

Many discourses on civil society participation - which were also inspired by the European Union - led to new international networks of associations, NGOs and foundations, strengthening the social enterprise while avoiding exclusion and promoting inclusion.

- The federal umbrella organization for social enterprises BDV Austria www.bdv.at -, 
for example, is a nationwide network and advocacy for social enterprises in Austria. It is also a founding member of ENSIE (European Network for Social Integration Enterprises).

- The World of NGOs (www.ngo.at) was founded in 1997 as a virtual platform for information and networking for associations, NGOs and foundations.

The European Union funded many EQUAL projects in the years 2000-2006 that encouraged transnational cooperation between different organizations in the social sector in order to test new ways of tackling discrimination and inequality in the labor market. (see [C (2000) 853 Official Journal C 127, 5.5.2000) It offered the opportunity to exchange know-how within the framework of development partnerships. So, under the European Community Initiative EQUAL, 118 organizations united to found the development partnership Danube-Quality in Inclusion. (www.donau-quality.at)

Operational and strategic partners discussed issues of commodification, the award and measurability of social services, the quality of social services, performance criteria and key numbers for social work, etc. There was a first confrontation with the new EU Services Directive (2004) that created new "market "- or competitive conditions for the social sector.

Criticism of new market conditions, managerialism and economization of social work

From approximately the new millennium, we can find various discourses and publications on "managerialism" in social work and in the social sector respectively, especially in connection with new control and steering models in the public sector. 
In 2007 KRISO (www.kriso.at) Kritische Soziale Arbeit - Critical Social Work -presented a "Wiener Erklärung zur Ökonomisierung und Fachlichkeit der sozialen Arbeit"-"Vienna Declaration on Economization and Professionalism in Social Work" that referred above all to external economic domination, measurability and standardization, competition and cost pressures. To understand the interactions between social economy, social management and social work historically, it is helpful to look at Sozialarbeit in Österreich-SIÖ "Social Work in Austria - SIÖ", the journal of the Professional Association of Social Workers in Austria (Austrian Association of Social Workers). It can be seen that already in the early 1990s not only individual articles but also editions with a thematic focus on issues such as organization and organizational development, public relations, social marketing or social sponsorship were published. This means that already at that time topics concerning social management were on the debate agenda.

Since 2002 several topics around the area of social economy (without talking about Social Economy) were in the thematic agenda of single issues of the journal SIÖ: the reflection on changing framework conditions of Social Work, a discourse about professional identity. Other topics were around the question of privatization and its meaningfulness, the debate on quality and what it means to social work and the clients of social workers; A further topic was leadership in social work organization. In 2015 there was a debate about social innovation. In conclusion you can say that The Professional Association of Social Workers in Austria (OBDS) did not really engage itself in social economy, but in social management topics. 


\section{Social Management and Social Economy Studies in Higher Education}

Since the 1990 s the tertiary education sector has reacted to numerous changes in the social sector by offering courses especially in social management. The term Social Economy can be found in the various study programs only from 2008 onwards - with one exception:

- Since 1966 the Faculty of Social Sciences, Economics and Business at the Johannes Keppler University Linz has continuously offered the study program Social Economy.

(see http://www.jku.at/content/e213/e64/e6350 [2015-09-20])

In recent years many other universities have offered university courses primarily on the free market in the field of social management, which explicitly took up the topic of social economy and even included it in their academic titles. Here are some examples:

- In 1993 Vienna University of Economics launched the further education course WBL social management ISMOS for education of management staff in the social sector through training linked to economic and social concerns and offered the possibility of reconciling economic and social thinking and acting. In 2014 this university course was renamed "Social Economy, Management and Organization of Social Services (ISMOS)".

(see http://www.bildungundberuf.at/ausbildung 186.html and http://www.wu.ac.at/fileadmin/wu/h/structure/about/publications/bulletin/pdfs/ot to8.pdf [2015 -09-20])

- Since 2000 the University of Krems / Lower Austria has offered a MSc university course "Social Management", which includes, among others, aspects of social economy. 
(see http://www.donauuni.ac.at/imperia/md/ content/ department/ kmbt/ gesundheitsfoerderung/socialmanagement/2 broschu_re_som-duk_11.12.pdf [2015-09-20])

The University of Salzburg launched a social management course to train the participants in operational and strategic skills for leadership activities in social economy enterprises.

(see http://www.uni-salzburg.at/fileadmin/oracle file imports/574602.PDF [2015-09-20]) Since 2014 it has been offered as a course in Social Economy with an MBA in Social Economy (see http://kompetenzzentrum2030at4.webnode.com/dienstleistungen/universitatslehrgang-sozialwirschaft/] [201509-20])

Since 2002 the University of Applied Sciences in Upper Austria (Linz) has offered the bachelor's degree program "Social Management". A master's degree program focuses on management of social enterprises, another master's degree addresses management of social innovations.

Fachhochschule Kärnten offers "Social Economy and Social Work" as an elective in the bachelor's degree program "Social Work".

In 2008 FH Campus Wien 2008 launched the master's degree program "Social Economy and Social Work" as the first Austria-wide program with a joint degree in cooperation with six other universities. (Degree: Master of Arts in Social Sciences).

In 2014 the bachelor's degree program "Social Management in Elementary Education" was launched at FH Campus Wien. 
Networks, Platforms, Associations and Umbrella Organizations and "The Big Five Players"

Since the early 1990s several further actors have been involved in the social sector. First of all in the wake of the implementation of the Care Allowance Act the "Big Five" charitable organizations (Caritas, Diakonie, Volkshilfe, Hilfswerk, Rotes Kreuz) established a "Bundesarbeitsgemeinschaft Freie Wohlfahrt" (Council of Charitable Organizations) in 1995 with the purpose of lobbying for social policy and welfare reforms and achieving better framework conditions for social organizations with public benefit orientation (see http://www.freiewohlfahrt.at/).

The "big five players" had a far longer tradition as members of an informal platform - the Austrian Committee for Social Work (ÖKSA) - in which the Ministry of Social Affairs, the three largest provincial governments (Vienna, Upper Austria and Lower Austria) and several further social organizations were represented. However, since the 1990s members of the social work profession have not been included any longer (see Melinz/Reder, 2006).

In 1997 a new umbrella organization - the "Berufsvereinigung von Arbeitgebern für Gesundheits- und Sozialberufe" (BAGS Association of Employers of Health and Social Professions) was founded. After some years and an extensive discussion process with two trade unions in 2003 they were finally able to reach a wage agreement (BAGS), which has been valid since 2004 - but only for a limited number of charitable organizations. Diakonie, Caritas and other social work organizations nevertheless have independent wage agreements with their employees in the social and health sector.

In April 2012 the BAGS Association was renamed to "Sozialwirtschaft Österreich" (Social Economy Austria - SEA). In accordance with its function as 
an employer association SEA has been striving for a better Procurement Law and increased financial resources to provide social services (see Dachverband et al, 2014).

A further umbrella organization representing social enterprises

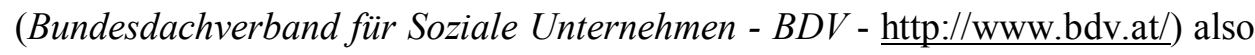
acts in the interest of employers.

Both umbrella organizations have been advocating for a better welfare state and more financial support for their inclusive social work and social services.

\section{The size and funding structure of the Austrian social economy}

As there are no official definitions of what constitutes the Austrian social economy it is also not possible to make a definite statement about the exact size of the sector or its economic importance for the Austrian economy. Some experts define social economy as non-profit organizations delivering social services, others also include public and private for-profit organizations which deliver social services. Moreover, the Austrian statistical office does not regularly gather statistical data on the social economy, organizations are not obliged to report, and therefore, existing statistics are not very exact. Austria does not have a nonprofit satellite account as recommended by the UN and as implemented by various European countries (UN 2003). Nevertheless, in recent years several efforts have been undertaken in order to improve knowledge about the sector, mostly concentrating on surveys on non-profit organizations.

The ÖNACE, the Austrian NACE classification, could serve as a starting point for an exact definition of what counts as a social economy organization. The NACE classification is a European classification system of economic activities, thus classifying all economically active organizations in different industries. In defining social economy with this classification system, several problems ap- 
pear: First, it remains unclear which sub-categories count as relevant to social economy. Second, we find that the categorization is extremely imprecise or undifferentiated in the most important categories relating to it. As for the NACE, classification sector Q "Human health and social work activities" is an obvious starting point for defining social economy, with the subsector 88 "Social work activities without accommodation" as the core category. In addition, subsector 87 "Residential care activities" falls into its definition.

With respect to the first problem it remains unclear whether parts of subsector 86 "Human health activities" count as social economy organizations or rather as health organizations: Relevant fields in this category could be ambulances and rescue services as well as domiciliary care / mobile home care. It is also unclear whether (or which) child care institutions count as educational services or social services. Finally, it cannot be ruled out that organizations in sector S 9490 "Activities of other membership organizations" sporadically deliver social services, too and thus should be counted as social economy organizations.

With respect to the second problem it is interesting to examine subsector 88 "Social work activities without accommodation" more closely: This subsector is further divided into "Social work activities without accommodation for the elderly and disabled" and into "Other social work activities without accommodation". Most activities of social economy organizations fall into this last residual category, so that it is not possible to differentiate between various important activities of social economy organizations.

Table 1 below summarizes important NACE categories for the definition of social economy: 
P - Education

P85 - Education

85.10 - Pre-primary education

Q - Human health and social work activities

Q86 - Human health activities

86.90 - Other human health activities

Q87 - Residential care activities

87.10 - Residential nursing care activities

87.20 - Residential care activities for mental retardation, mental health and

87.30 - Residential care activities for the elderly and disabled

87.90 - Other residential care activities

Q88 - Social work activities without accommodation

88.10 - Social work activities without accommodation for the elderly and disabled

88.90 - Other social work activities without accommodation

88.91 - Child day-care activities

88.99 - Other social work activities without accommodation n.e.c.

Source: Eurostat

Table 1: Relevant NACE categories

It is not possible to determine the size of the sector precisely due to varying definitions of the sector and due to the statistical problems mentioned above. Consequently, we find enormous variations in existing estimations of the sector size, which is sometimes somewhat confusing:

According to the data of the Austrian statistical office, in 2012 there were 2,420 organizations in the sectors 87 and 88, which employed approximately 103,250 persons (Statistik Austria, 2015a). These figures do not take into account all other possibly relevant categories mentioned above, thus probably underestimating the size of the sector.

In another statistics Statistics Austria reports 34,706 organizations in sectors 87 and 88 for the same year (Statistik Austria, 2015b). This great variation in the figures is due to a difference in the statistical definition of "organization": The first definition only counts businesses with a sales revenue above $10,000 €$ and busi- 
nesses which were active throughout the year, whereas the second definition does not include the sales clause and also counts businesses active less than 12 months. A work site survey carried out by Statistics Austria in the year 2001 counted 9,678 work sites in the social service sector including mobile care and child care institutions, with an organization possibly having more than one work site (Schneider and Trukeschitz, 2005). In their study Dimmel and Schmid (2013) estimate that approximately 6,300 associations, 300 limited liability companies $(\mathrm{GmbH})$ and 20 cooperatives provided social services in 2012, and can therefore be considered social economy organizations. This estimation, however, does not include public or for-profit organizations as social economy organizations and consequently underestimates the "true" size of the social economy - again, due to the definition of the social economy sector.

As already mentioned, the Austrian social economy consists of public, private non-profit as well as private for-profit organizations. The mix of institutional providers varies in the different subsectors. Certain service areas are dominated by non-profits (e.g. mobile home care / domiciliary care), whereas others almost exclusively by public organizations, yet, in others, we find a mix of non-profit, for-profit and public providers.

In the course of the work site survey of Statistics Austria in 2001 the degree of the welfare mix was determined (see Table 2): 


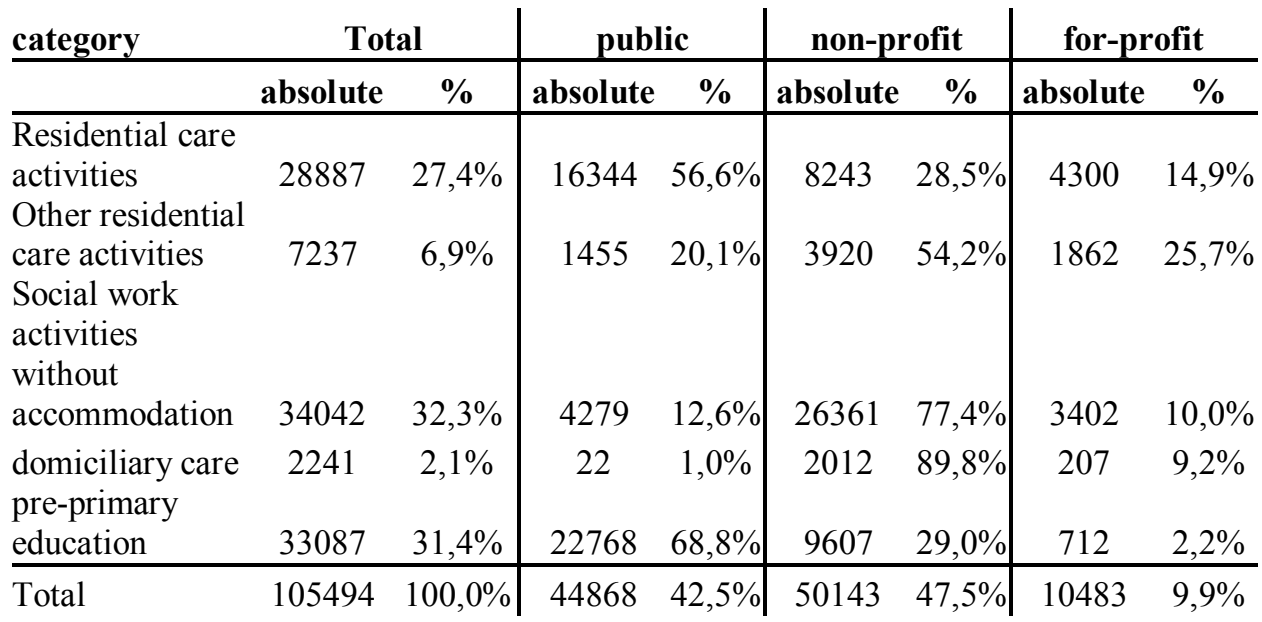

Source: Schneider, Trukeschitz 2005: 26

Table 2: Employees in the social economy - distribution between institutional sectors

In total, we find a fairly even distribution between the public and the non-profit sector, the latter playing a minor part. The non-profit sector is strongest in the categories "Other residential care", "Domiciliary care" as well as "Social work activities without accommodation", which is one of the core categories in the social economy.

However, this mix of institutional providers has changed over the past 20 years. As there are no explicit official statistics on the mix, it is difficult to track this development. Nevertheless, it is possible to look into specific sub-sectors such as the residential care sector which are better documented statistically. Here we find a shift towards private provision and a corresponding decrease in public provision. In $198776 \%$ of all beds of residential care homes were in public care homes, in 2010 this figure fell to $47 \%$. By contrast, beds in for-profit homes rose from $2 \%$ in 1987 to $19 \%$ in 2010 . The relative importance of the non-profit sec- 
tor rose slightly from $22 \%$ in 1987 to $33 \%$ in 2010 (Neumayr, Meichenitsch, 2011:76).

This shift can be seen as pars pro toto in the whole social economy. As in many other European countries, the Austrian social economy can be characterized as a very dynamic sector with growing marketization efforts. Over the last 20 years, the conditions and regulations concerning the provision of social services have changed considerably (Heitzmann, Österle, Pennerstorfer, 2015). The public authorities have sought to establish a quasi-market by introducing public tendering and more detailed contractual arrangements. This has led to increasing competition among non-profit organizations and also to market-entry of for-profits. Alongside these changes, also the funding structure of social economy organizations has changed over the past 20 years.

in \% von total income

\begin{tabular}{|c|c|c|c|c|c|c|}
\hline activity & $\begin{array}{c}\text { Sales } \\
\text { Revenue }\end{array}$ & Subsidies & $\begin{array}{c}\text { wage } \\
\text { subsidies }\end{array}$ & $\begin{array}{c}\text { member } \\
\text { fees }\end{array}$ & donations & sponsoring \\
\hline $\begin{array}{l}\text { non-profit care } \\
\text { homes }\end{array}$ & $77.0 \%$ & $22.2 \%$ & $0.4 \%$ & $0.0 \%$ & $0.4 \%$ & $0.0 \%$ \\
\hline $\begin{array}{l}\text { public care } \\
\text { homes }\end{array}$ & $56.0 \%$ & $43.9 \%$ & $0.1 \%$ & $0.0 \%$ & $0.0 \%$ & $0.0 \%$ \\
\hline $\begin{array}{l}\text { for-profit care } \\
\text { homes }\end{array}$ & $98.8 \%$ & $1.2 \%$ & $0.0 \%$ & $0.0 \%$ & $0.0 \%$ & $0.0 \%$ \\
\hline $\begin{array}{l}\text { non-profit } \\
\text { child care } \\
\text { institutions }\end{array}$ & $79.6 \%$ & $18.9 \%$ & $0.3 \%$ & $0.0 \%$ & $1.0 \%$ & $0.2 \%$ \\
\hline $\begin{array}{l}\text { public child } \\
\text { care } \\
\text { institutions } \\
\end{array}$ & $37.5 \%$ & $62.5 \%$ & $0.0 \%$ & $0.0 \%$ & $0.0 \%$ & $0.0 \%$ \\
\hline $\begin{array}{l}\text { for-profit child } \\
\text { care } \\
\text { institutions }\end{array}$ & $57.6 \%$ & $42.4 \%$ & $0.0 \%$ & $0.0 \%$ & $0.0 \%$ & $0.0 \%$ \\
\hline $\begin{array}{l}\text { other social } \\
\text { services }\end{array}$ & $74.7 \%$ & $12.0 \%$ & $1.1 \%$ & $0.6 \%$ & $11.5 \%$ & $0.1 \%$ \\
\hline
\end{tabular}

Source: Schneider, Haider 2009: 34

Table 3: Income structure of selected activity groups (for 2006) 
Table 3 presents the income structure of selected social economy organizations. Note that the sales revenue category includes income from service contracts with public agencies. For-profit organizations rely on sales revenues to large big extent, while public organizations have the most subsidies. Table 4 compares the income structure of non-profit social economy organizations in 2006 with the same organizations in 2013. We find a shift from subsidies to income from service contracts (as reflected in the category sales revenues).

\begin{tabular}{c|cccccc} 
Year & $\begin{array}{c}\text { Sales } \\
\text { revenues }\end{array}$ & $\begin{array}{c}\text { current } \\
\text { transfers } \\
\text { (received) }\end{array}$ & Subsidies & $\begin{array}{c}\text { donations } \\
\text { in-kind } \\
\text { (received) }\end{array}$ & $\begin{array}{c}\text { other } \\
\text { income }\end{array}$ & sum \\
\hline 2006 & $78,7 \%$ & $3,4 \%$ & $15,5 \%$ & $0,9 \%$ & $1,4 \%$ & $100,0 \%$ \\
2015 & $86,0 \%$ & $3,1 \%$ & $9,9 \%$ & $0,3 \%$ & $0,7 \%$ & $100,0 \%$
\end{tabular}

Source: Pennerstorfer, Schneider, Reitzinger 2005: 41

Table 4: Income structure for social economy organizations in 2006 and 2013

Previously, arrangements between the public authorities and the non-profit organizations were rather vague and based on a long tradition of cooperation. These arrangements have now changed into more formal ones, with the funding scheme changing from lump-sum subsidies to performance-based pay schemes that require (more) elaborate documentation. Public requirements - in parts strongly interfere in the organization, sometimes regulating the organizational structure, the personnel structure, formal education requirements or setting prices for single services.

One interesting and singular example for these changes can be found in Vienna. The City of Vienna "outsourced" parts of its social services by creating the Fonds Soziales Wien (FSW - Vienna Social Fund) (www.fsw.at), established in 2001. The FSW is in the legal sense private-sector enterprise acting on behalf of the City of Vienna, but which can still be defined as a (semi-) public institution, 
since it exercises control. The FSW is partly a (public) provider of social services and partly a (public) purchaser. In the latter role this agency plans offered services, procures services, issues contracts, provides funds and monitors offered service quality, and thus exerts market power as the (often) sole (monopsonic) consumer (in the sense of being the legal person paying for services).

The goals or expected outcomes of the introduction of the quasi-market were better offered services alongside lower prices. For Austria, it has been shown that larger organizations have benefited from the complex funding structure. Competition has led to lower prices, rather than higher quality, along with a deterioration of working conditions in the social sector (Dimmel, 2012). Diebäcker et al. (2009a, 2009b) draw a similar picture by describing changes in the organizational culture, a loss of organizational autonomy as well as work overload for employees.

\section{Conclusion}

As shown, social economy is not a well-established term in Austrian society and economy and it remains unclear what exactly can and can't be incorporated in the term. While we show diverse definitions and approaches, a more accurate description would be public and private organizations that provide social services - consisting of organizations of different legal forms, with associations and private limited liability companies being the most important ones in Austrian social economy. We describe the development of the Austrian mixed economy of welfare, having quite a long tradition of division of work between the public and the non-profit sectors. Nowadays, the Austrian social economy organizations are self-confident actors in Austrian social politics, but at the same time they are experiencing challenging changes especially concerning their relation to the public authorities. 


\section{References}

Austrian Tax Code 2015: Bundesabgabenordnung BGBl. I Nr. 118/2015

Biffl, G. (1994): Evaluierung von Instrumenten der experimentellen Arbeitsmarktpolitik. Gutachten im Auftrag des Bundesministeriums für Arbeit und Soziales. Wien - http://gudrun.biffl.wifo.ac.at/fileadmin/files/EXPAMP.PDF [22.9.2015])

dabei-Dachverband, berufliche Integration Austria, Sozialwirtshaft Österreich/bdv Austria (2014): Positionspapier zur Beauftragung von Sozialen Dienstleistungen [http://www.bags-kv.at/1001,4035,0,2.html]

Diebäcker M, Ranftler J, Strahner T, et al. (2009a): Neoliberale Strategien und die Regulierung sozialer Organisationen im lokalen Staat. Von der Ökonomisierung des Politischen zur Depolitisierung der Sozialen Arbeit - Teil I. soziales kapital 2009

Diebäcker M, Ranftler J, Strahner T, et al. (2009b): Zeugnisse alltäglichen Leidens in sozialen Organisationen. Von der Ökonomisierung des Politischen zur Depolitisierung der Sozialen Arbeit - Teil II. soziales kapital 2009.

Dimmel, N. (2012): Sozialwirtschaft unter Prekarisierungsdruck. WISO 2012: $27-47$

Dimmel, N. \& Schmid, T. (2013): Soziale Dienste in Österreich (Social services in Austria), Innsbruck et al.: Studienverlag

Dokumentation über den 1. Kongress der Sozialwirtschaft in Österreich und die Kampagne des Netzwerk Sozialwirtschaft (2005): So sozial wie wirtschaftlich: Sozialwirtschaft in Össterreich. Wien 
European Commission (2012): Communication from the Commission to the European Parliament, the Council, the European Economic and Social Committee and the Committee of the Regions Entrepreneurship 2020 Action Plan reigniting the entrepreneurial spirit in Europe, (Com [2012/0795 final])

European Commission (2014a): A map of social enterprises and their ecosystems in Europe. Executive Summary. Brussels

European Commission (2014b): A map of social enterprises and their ecosystems in Europe. Country Report: Austria. Brussels

European Foundation Centre (2011): Comparative Highlights of Foundation Laws. The Operating Environment for Foundations in Europe. Brussels

Fundraising Verband Austria (2014): Spendenbericht 2014. Wien

Heitzmann, K., Österle, A. \& Pennerstorfer, A. (2015): Soziale Dienstleistungen in Österreich: Zwischen Anspruch und Wirklichkeit. In: Politische Ökonomie Österreichs. Kontinuitäten und Veränderungen seit dem EU-Beitritt, Hrsg. Beigewum, Wien: Mandelbaum. pp 120-131.

Lechner, F., Loidl, R., Mitterauer, L., \& Riesenfelder, R. W. (2000). Evaluierung Sozialökonomischer Betriebe. Endbericht an das Arbeitsmarktservice Österreich, Wien

Melinz, G. (2003): Von der Armenfürsorge zur Sozialhilfe. Zur Interaktionsgeschichte von ,,erstem “ und ,,zweitem “ sozialem Netz in Österreich am Beispiel der Erwachsenenfürsorge im 19. und 20. Jahrhundert. Habilitationsschrift Universität Wien 
Melinz, G. \& Reder, W. (2006): 50 Jahre ÖKSA. Eine politische Plattform für soziale Arbeit im Wandel der Zeit. Wien, Österreichisches Komitee für Soziale Arbeit

Monzon, J. L. \& Chavez, R. (2012): The Social Economy in the European Union. Brussels: European Economic and Social Committee

Neumayr, M. \& Meichenitsch, K. (2011): Sind Non-Profit-Organisationen die Guten? Qualitätsunterschiede zwischen gemeinnützigen und gewinnorientierten Alten- und Pflegeheimen. Kurswechsel 2011. pp 75-85

Pennerstorfer, A., Schneider, U. \& Badelt, C. (2013): Der Nonprofit Sektor in Österreich (The non-profit sector in Austria). In: Simsa Ruth, Meyer Michael and Badelt Christoph (eds) Handbuch der Nonprofit-Organisationen. 5. überarbeitete Auflage ed. Stuttgart: Schäffer-Poeschel. pp 55-75

Pennerstorfer, A., Schneider, U. \& Reitzinger, S. (2015): Nonprofit Organisationen in Österreich 2014. Wien: WU Wien, Institut für Sozialpolitik

Roess1, D. \& Reiner, E. (2010): National Report Austria. In: Study on the implementation of the Regulation 1435/2003 on the Statute for European Cooperative Society (SCE). Part II. National Reports. pp 325-342

Schneider, U. \& Haider, A. (2009): Nonprofit Organisationen in Österreich 2006. Wien: WU Wien, Institut für Sozialpolitik

Schneider, U. \& Trukeschitz, B. (2005): Definitionen und Dimensionierung des "Sozialsektors" in Österreich. Studie des Instituts für Sozialpolitik der Wirtschaftsuniversität Wien im Auftrag des Bundeseinigungsamtes beim BMWA. 
Schneider, H., Millner, R., \& Meyer, M. (2015): Austria Country Report. EUFORI Study. Brussels: European Commission

Sozialwirtschaft ist ... Diskussion mit Nikolaus Dimmel, Andreas Riesenfelder und Ruth Simsa, moderiert von Veronika Litschel und Petra Wetzel (2004) In: Kurswechsel Heft 4, pp 7-15

Statistik Austria (2015a): Statistik zur Unternehmensdemographie bis 2014. Accessed on stat.cube:

http://statcube.at/statistik.at/ext/superweb/loadDatabase.do?db=dereg_udemo. $[4 / 8 / 2015]$

Statistik Austria (2015b): Statistik zur Unternehmensdemographie ab 2015. Accessed on stat.cube:

http://statcube.at/statistik.at/ext/superweb/loadDatabase.do? $\mathrm{db}=$ dereg_udemo ne $\underline{\mathrm{u}}[4 / 8 / 2015]$

Stichlberger, K. (2012): Die gemeinnützige GmbH als Alternative zum Verein nach dem VerG 2001. Errichtung und Besteuerung einer gGmbH am Beispiel des Medizinischen Expertenrings. Bachelorarbeit FH Oberösterreich: Linz

United Nations (2003): Handbook on Non-profit Institutions in the System of National Accounts. New York: United Nations.

http://unstats.un.org/unsd/publication/seriesf/seriesf 91e.pdf [2015-07-31]. 


\section{Social Policy and Social Economy in Slovakia}

\section{Ondrej Botek}

\section{History of social policy and social economy in Slovakia from 1918}

Social economy and social policy are very closely connected areas of theory and practice within various fields of research and practice. Therefore it is necessary to see these areas in their relations. Understanding of social economy is historically determined. In current times it could be understood as initiatives such as redistribution of income and wealth within market economy, various allocation systems and their governance, solidarity and reciprocity relations, as well as the role of public, private and third sector in operating and governing social economy (Salomon and Anheier, 1995; Laville and Delfau, 2000; Leyshon et al., 2003). We can identify some forms of what could be called social economy already in ancient and medieval times. Rules in the Old Testament, initiatives like Roman colleges, Greek funds, medieval guilds and friendly societies are just some of the examples from our history. But I would like to focus on history of social economy in Czechoslovakia and Slovakia after constitution of Czechoslovak Republic in 1918 and later Slovak Republic in 1993. There are strong roots for social economy initiatives Czechoslovakia from 20ties and 30ties of last century. It is estimated that there was more than 16.000 various friendly societies only in Slovakia before World War II., 1.936 of them with main focus on health and social issues (Dudeková, 2015). This period could be proudly called a "Golden period" of social economy in history of Slovakia. This "golden period" is strongly connected to development of social policy that played supportive role by very progressive legislation, just to mention advanced Law on Social Insur- 
ance (1924) and many others. Intensive development of Social Work also appeared in this period; various schools for social workers were established.

This period was interrupted during World War II. and short period of "recovery" appeared after the end of the WWII. Unfortunately this period was politically slightly terminated from 1945. Since 1948 trend of elimination has increased and process of political integration and indoctrination has a massive influence on activity of these initiatives.

Process of changes after 1948 was characterized by nationalization of private property and transition to paternalistic forms of social policy. Market economy was stipulated by centrally planned economy with dominant role of state (Botek, 2009). Whole system could be defined as a complex, state financed custody of employed and their families, where many of social problems were ideologically abolished, as well as social education. These changes had a massive influence on social economy initiatives that were suppressed and politically indoctrinated. Social security passes through significant changes from progressive European social security system to Soviet type of social security, supplemented by paternalistic type of Social Care and doping of basic products. Social Insurance as one of standard three pillar system of Social Security was compulsory reduced as well as Social Assistance and Social Support pillar became dominant. Main source of financing Social Security was state budget, what resulted to uncertain and unclear system, characterized by universal and mostly obligatory allowances.

Employment was obligatory; unemployment was considered malfeasance (3-5 years imprisonment). Due to this employment policy artificial job creation was necessary, which leads to decreasing of labour productivity and partly also to lack of labour force in some areas of economy. 
Wage policy was characterized by central wage regulation, as state became in fact the only employer. Wages were assign base on three main facts:

1. Fulfilling the plan

2. Qualification and duration of practice

3. "Social usefulness" (Botek, 2009)

First fact emphasized fulfilling of plan (usually 5 years) as a major factor of efficiency, very often no matter of real economic efficiency. As a result, employees had not focus on real efficiency of their work, possible improvements or more efficient approaches.

Second fact stressed duration of practice and qualification, no matter what was real efficiency of employee. This caused lower level of motivation for improvement and development of more efficient approaches.

Third fact introduced particular favouritism of peasants and workers towards so called "working intellectuals". This favouritism creates inadequate differences in wages based on profession.

Due to domination of state institutions we can hardly speak about existence of independent third sector since 1950, therefore all social economy activities were realized by state.

Transformation of social policy and social economy development from 1989

Year 1989 brings massive changes in political, economic and social affairs. The end of socialism and beginning of building of democracy created acute need for transformation of existing systems. A previous social system does not fit the new situation, characterized by privatization, transition from centrally planned econ- 
omy to market economy, etc. New social problems, previously not existing, marginalised or hidden, appeared. Transformation process could be divided to two periods: period of "crisis solution" and period of transformation.

\section{The period of crisis solutions}

The main changes in the first years after 1989 I have divided to four main areas: Employment policy, wage policy, family policy and social security (Botek, 2009).

Employment policy: As already mentioned employment was an obligation for all people in productive age (except tenably unemployed) before 1989. State as the only employer had to provide sufficient number of jobs, which were very often created artificially - by employing more people for one job. This fact leads to lower productivity and efficiency of the employee. Privatization after 1989 give rise to unemployment due to abrogation of artificially created work places and unemployment as a new social phenomenon has appeared. As there were no institutions for unemployed, labour offices had to be created. Their main function was to provide of assistance for unemployed people at labour market and realize financial assistance. Employment Act, introduced in 1991, defined main responsibilities of Labour offices as well as unemployment allowance, set at the beginning on quite high level - first six months $90 \%$ and next six months $60 \%$ of previous income (Sociálna politika v Slovenskej republike v roku 2001, 2002).

Wage policy: As already mention state as the only employer before 1989 regulated all wages with Central wage regulation. After privatization new private employers appeared at labour market and conditions had to be adapted. Until 
that time not existing minimal wage was established in February the $1^{\text {st }} 1991$. Act 1/1992 abolishes central wage regulation and introduced individual and collective bargain.

Family policy: Family policy went through massive changes too. Substantial move from pro-natality policy to higher protection of families, especially those in risk of poverty as another new phenomenon could be observed. Major changes were visible in family benefits system, reduction of preschool institution, and transformation from institutional substitute care to more family oriented forms.

Social security: Transformation of social security was one of the crucial points of transformation. Previous system nearly destroyed social insurance as one of three main pillars of social security. State dominates social security as provider as well as financial source and social support pillar massively dominated social security. The main idea of transformation of social security could be defined as "from social care to social assistance". Due to new social problem of poverty, new approaches have to be introduced. As one of the first poverty line has was established by the Act 463/1991 of living minimum. Act 43/1991 introduced valorisation of pensions due to increase of living costs. National insurance company was established in 1993 (later divided to Social Insurance Company and Health Insurance Company - 1994) (Botek, 2014).

\section{Transformation and principles}

Year 1996 brings substantial move from already mentioned period of "crisis solutions" to real transformation process. This could be observed in variety of complex conceptions as Conception of State Family Policy, Conception of Employment Policy, introduction of supplemental pension insurance, etc. Subsequent years brings important changes, just to mention: Act 50/1995 on Social Security, Act 195/1998 of social assistance, Transformation of Pension system 
(2003) - implementation of three pillar system, creation of capitalization pillar, Act 461/2003 of Social Insurance, transformation of social services (2006) and new Social services Act 448/2008 (Botek, 2014).

Tomeš (2010) define ten main principles in the transformation process:

Demonopolization as one of the main principles should ensure plurality of subjects, active in social sphere, abolish the exclusive role of state and create a space for NGO subjects that would be mentioned later.

Decentralization of public sphere should move governance and realization of social protection as close as possible to people, implement subsidiarity and remove rights and responsibilities to regional and local authorities in collaboration with civil society initiatives.

Democratization stress legal independence of institutions and inclusion of selfgoverning elements in the administration on all levels of governance (administrative and supervisory boards, Commission, etc.).

Modification of object, as another principle, focus on change of the position of client of various services. This principle stress importance of perception of client not as a member of the group but as an individual with particular needs.

Pluralisation of sources emphasise the need of leaving one source financing of social policy (from state budget) and to create multisource system of financing, using of various sources including European fund, private sources, foundations, etc.

Pluralisation of types and forms focus on superseding non-alternative systems by plural systems of social protection; include those provided by private and non-governmental initiatives.

Humanization stresses the need of inclusion of individuals with social problems and tendency to provide of assistance in natural surroundings. This principle is connected to the process of deinstitutionalization. 
Reconfiguration to needs is another principle that emphasise transformation of social services, which should provide of more adequate social protection in terms of time, extent, intensity of problem, etc.

Personification stresses the need of approximation of service provider and the client, support the reliance and confidence in social services.

Professionalization as a last principle emphasise the need of including of professionals in social protection, especially in terms of re-establishing university education in Social Work and related study programs.

\section{Social economy development after 1989}

After the fall of socialism in 1989, new freedom and opportunities for civic activism and associations have opened and new activities started to flourish. New actors - active citizens and their structures - Non-governmental organizations and other independent bodies - started to play an increasing role in the Slovak society (Pavelek, 2014). Development of civil society initiatives could be divided to five periods: diversification, consolidation a professionalization, emancipation, mobilization and stabilization (Ondrušek - Matijek, 2000).

First period of diversification was typical for first years after democratic changes approximately to 1992. Massive increase of NGOs was a result of breakdown of large organisations from socialism period. These new organisations redefined their aims and focus. Right after this period in 1992-1993 already existing organisations started to consolidate and became more professional as their members and leaders participated on various training programs and study mobility abroad. Number slowly decreased due to not reaching expectations. Period of emancipation was closely connected to the result of elections in 1994, when authoritative government was created and massive tension in relations between government and civil society organizations could be observed. From 1994 1997 the number of NGOs increase again due to this tension. It is estimated that 
there were 158 NGOs in 1990 and the number massively increased to nearly 10.000 in 1996 (Mydlíková, 2009).

\begin{tabular}{|l|c|c|c|c|c|c|c|c|c|c|}
\hline Legal form & $\mathbf{1 9 9 0}$ & $\mathbf{1 9 9 5}$ & $\mathbf{1 9 9 6}$ & $\mathbf{2 0 0 0}$ & $\mathbf{2 0 0 2}$ & $\mathbf{2 0 0 3}$ & $\mathbf{2 0 0 4}$ & $\mathbf{2 0 0 5}$ & $\mathbf{2 0 0 6}$ & $\mathbf{2 0 0 7}$ \\
\hline $\begin{array}{l}\text { Civil } \\
\text { association }\end{array}$ & 9976 & 7819 & 1541 & 20803 & 20575 & 23789 & 23622 & 27906 & 27416 \\
\hline $\begin{array}{l}\text { Non-investing } \\
\text { funds }\end{array}$ & 136 & 280 & 345 & 440 & 513 & 493 & 555 & 552 \\
\hline $\begin{array}{l}\text { Non-profit } \\
\text { organization }\end{array}$ & & & 123 & 215 & 397 & 831 & 845 & 1365 & 1514 \\
\hline Foundation & & 1687 & 1950 & 480 & 553 & 249 & 305 & 276 & 475 & 362 \\
\hline Totally & $\mathbf{1 5 8}$ & $\mathbf{1 1 6 6 3}$ & $\mathbf{9 9 0 5}$ & $\mathbf{2 4 2 4}$ & $\mathbf{2 1 9 1 6}$ & $\mathbf{2 1 6 6 1}$ & $\mathbf{2 5 4 3 8}$ & $\mathbf{2 5 2 3 6}$ & $\mathbf{3 0 3 0 1}$ & $\mathbf{2 9 8 4 4}$ \\
\hline
\end{tabular}

Source: Mydliková, 2009

Table 1.: Number of NGOs by legal form $1990-2007$

Period of mobilization started in 1997 before the elections that were crucial for future political orientation of Slovakia. After mentioned elections that brought political change and moved Slovakia back to the way to European structures, period of stabilization could be observed. This period was characterized by decrease of the number of NGOs and improvement of relations between state and NGOs on all levels of governance. There were different reasons of decrease of number of NGOs in this period. One of them could be loss of the main enemy, another spontaneous clearance of the sector as well as decrease of finances invested to this field (Mydlíková, 2009). New legislation improving environment for civil initiatives were introduced. Since 2000 we could again observe an increase on NGOs, fortunately not affected by negative political situation. This trend could be explained by amendment of tax legislation that allowed individuals to donate $1 \%$ of taxes to non-profit organisation. This amount was later increased to $2 \%$ in 2004 . Year 2002 brought intensive processes of decentraliza- 
tion that created pressure on participation of NGOs. Unfortunately, many of these NGOs were not prepared for such a pressure due to long lasting absence of subsidiarity. This is the reason, why process of decentralization did not continued as planned. In 2005 Slovakia belongs to countries with highest level of centralization. Proportion of expenditures of local governments on total expenditures was less than $13 \%$, comparing to Hungary $-25 \%$, Poland - $20 \%$, Denmark $-45 \%$, Sweden $-50 \%$ or European average - 20\% (Nižnanský, 2005).

Current period could be called a period of Europeanization that is characterized by higher pressure on NGOs autonomy and self-reliance, ability to operate without (or with less) assistance (of "European money"), more efficient use of local sources and increase participation of inhabitants.

\section{Current understanding of social economy}

It is not an easy task to define current understanding of social economy, as concepts of social economy vary massively. The term "social economy" if often use as a synonym for Social Capital, Solidarity Economy, Third sector, Alternative Economy, Voluntary Sector, etc. Most of the understandings concentrate and stress specially the role of Third sector, Non-profit sector, Non-for-profit sector, Nongovernmental organisation, etc. Table 2 illustrates some understandings of social economy, as defined by Moulaert and Ailenei (2005). In this chapter we would understand social economy as initiatives providing of redistribution of income and wealth within market economy, various allocation systems and their governance, solidarity and reciprocity relations supporting activities, as already mentioned above (Salomon and Anheier, 1995; Laville and Delfau, 2000; Leyshon et al., 2003). So we would focus not only on NGO initiatives, but also public and private bodies and their activities, fulfilling mentioned criteria. 


\begin{tabular}{|c|c|c|c|}
\hline \multicolumn{4}{|c|}{ Social Economy } \\
\hline \begin{tabular}{|ll} 
Concepts and \\
dimensions
\end{tabular} & Social Economy & Third Sector & $\begin{array}{l}\text { Solidarity Econ- } \\
\text { omy }\end{array}$ \\
\hline $\begin{array}{l}\text { 1. Institutional } \\
\text { and political di- } \\
\text { mension and his- } \\
\text { torical perspective }\end{array}$ & $\begin{array}{l}19^{\text {th }} \text { century: Institutionalise } \\
\text { better wages, better work } \\
\text { conditions, consumer satis- } \\
\text { faction } \\
1930 \mathrm{~s} \text { : housing and food } \\
\text {-cooperatives to avoid blunt } \\
\text {-poverty } \\
\text { 1970s: sustainable social } \\
\text { entrepreneurship rr } \\
\text { Post-1980s: r worker- } \\
\text { oriented co-operatives, } \\
\text { LETS }\end{array}$ & $\begin{array}{l}\text { Immediate response } \\
\text { to crisis of work and } \\
\text { society in the } 1980 \mathrm{~s}\end{array}$ & \\
\hline $\begin{array}{l}\text { 2. Property and } \\
\text { control relations }\end{array}$ & $\begin{array}{l}\text { Regulatory role of state } \\
\text { (social justice): non for } \\
\text { profit? } \\
\text { Members are stakeholders }\end{array}$ & $\begin{array}{l}\text { Non-profit? But in } \\
\text { Europe also co- } \\
\text { operatives }+ \text { mutual } \\
\text { organisations }\end{array}$ & Civil S \\
\hline $\begin{array}{l}\text { 3. Type of „Core, } \\
\text { agent }\end{array}$ & $\begin{array}{l}\text { Firms with social objec- } \\
\text { tives or social inspired } \\
\text { work organisations (co- } \\
\text { operatives, mutuelles) }\end{array}$ & $\begin{array}{l}\text { Defined at level of } \\
\text { sectored interaction } \\
\text { (meso-economic) or } \\
\text { associative agents }\end{array}$ & Botto \\
\hline $\begin{array}{l}\text { 4. Market orienta- } \\
\text { tion }\end{array}$ & $\begin{array}{l}\text { Most core agents operate at } \\
\text { the market but according to } \\
\text { solidarity principles }\end{array}$ & $\begin{array}{l}\text { Partly quite eclectic } \\
\text { definition } \\
\text { (see Lévesque et al., } \\
\text { 1999) }\end{array}$ & $\begin{array}{l}\text { Neither market nor } \\
\text { state? Synergies } \\
\text { with market and } \\
\text { state sector }\end{array}$ \\
\hline $\begin{array}{l}\text { 5. Model of Co- } \\
\text { operation - social } \\
\text { bond - organisa- } \\
\text { tional model }\end{array}$ & $\begin{array}{l}\text { Solidarity practices } \\
\text { guilds, confraternities, co- } \\
\text {-operative, associative } \\
\text { mutual aid practice }\end{array}$ & $\begin{array}{l}\text { Large component of } \\
\text { voluntary work }\end{array}$ & $\begin{array}{ll}\text { Hybridisation } & \text { of } \\
\text { market: non- } \\
\text { market and non- } \\
\text { monetary }\end{array}$ \\
\hline $\begin{array}{l}\text { Contemporary } \\
\text { definition }\end{array}$ & $\begin{array}{l}\text { Historical-eclectically inte- } \\
\text { grating, most dimensions of } \\
\text { social economy in previous } \\
\text { epochs: social objectives, } \\
\text { reciprocity + solidarity, self- } \\
\text { management, state-regulated }\end{array}$ & $\begin{array}{l}\text { Social economy ini- } \\
\text { tiatives by agents of } \\
\text { civil society } \\
\text { Associations }\end{array}$ & 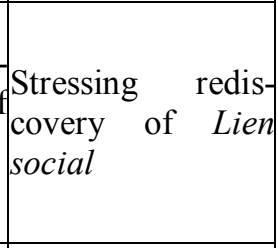 \\
\hline Related concepst & Non-lucrative sector & $\begin{array}{l}\text { Not-for-profit, } \\
\text { Independent sector } \\
\text { (UK), } \\
\text { Non-profit (US) }\end{array}$ & Voluntary sector \\
\hline
\end{tabular}

Source: Moulaert, Ailenei, 2005

Table 2.: Social economy understandings 
If we look on Third sector, different from traditional public "general interest serving" and the private market sector, that combines: formal in informal elements at the level of organization (market, state, volunteering, self-help and domestic economy), market and non-market-oriented production and valorisation of goods and services, monetary and non-monetary resources at the level of funding. Generally speaking, the term social economy designates the universe of practices and forms of mobilising economic resources towards the satisfaction of human needs that belong neither to for-profit enterprises, nor to the institutions of the state in the narrow sense (Moulaert - Ailenei, 2005). Essentially, the social economy is made up of the voluntary, non-profit and co-operative sectors that are formally independent of the state. Their market activities are means of achieving social development goals that transcend the market per se. Thus defined, the social economy should be logically considered as a third sector (Browne, 1997). As already mentioned, third sector went through difficult reestablishment after 1989 with many ups and downs. Implementation of some of the principles that were mentioned in previous part was quite successful, but some principles are still not reached, especially demonopolization, decentralization and pluralisation of sources. As shown in chart 1 and table 3, general government contributions are still high in Slovakia and Czech Republic, and so state is still the main source of financing of social protection and although there is a space for non-governmental subjects, state still plays the main role. 


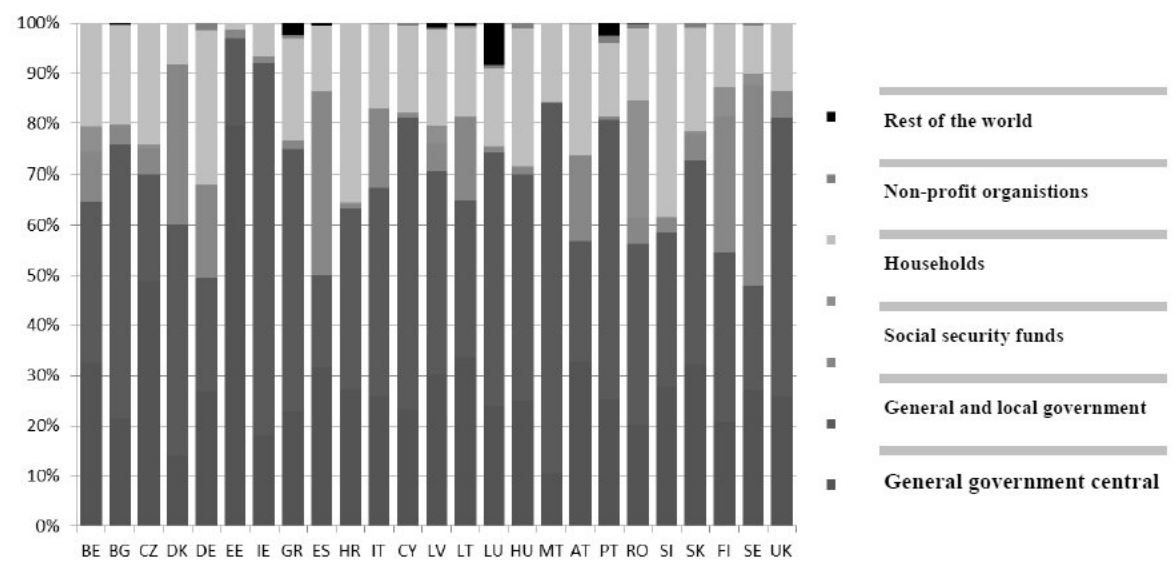

Source: ESSPROS, 2014

Chart 1.: Receipts of social protection by sector of origin (\% of total receipts), 2012

Social contributions of protected persons are one of the lowest in Europe, as well as $\%$ of GDP. These particularities are similar in all post-socialism countries.

\begin{tabular}{|c|c|c|c|c|}
\hline Country & $\begin{array}{c}\text { Employers } \\
\text { social } \\
\text { contributions }\end{array}$ & $\begin{array}{c}\text { Social contribu- } \\
\text { tions by pro- } \\
\text { tected persons }\end{array}$ & $\begin{array}{c}\text { General } \\
\text { government } \\
\text { contributions }\end{array}$ & $\begin{array}{c}\text { Other } \\
\text { recipts }\end{array}$ \\
\hline Slovakia & 40,8 & 18,77 & 37,6 & 2,9 \\
\hline Czech Republic & 49,3 & 23,98 & 25,3 & 1,5 \\
\hline Hungary & 37,7 & 22,66 & 36,9 & 2,7 \\
\hline Poland & 44,7 & 19,41 & 16,4 & 19,5 \\
\hline Austria & 36,5 & 25,94 & 36,0 & 1,6 \\
\hline Germany & 33,9 & 29,75 & 34,6 & 1,8 \\
\hline France & 41,7 & 20,14 & 35,0 & 3,2 \\
\hline Romania & 34,2 & 14,1 & 50,7 & 1,0 \\
\hline United & 27,7 & 12,4 & 53,2 & 6,7 \\
\hline Kingdom & & & & 2,1 \\
\hline Sweden & 36,2 & 9,6 & 52,2 & 1,6 \\
\hline Italy & 37,5 & 14,63 & 46,3 & 0,9 \\
\hline Spain & 43,7 & 12,4 & 43,0 & 10,4 \\
\hline Switzerland & 30 & 35,19 & 24,4 & 5,9 \\
\hline Finland & 34,8 & 12,5 & 46,9 & \\
\hline
\end{tabular}

Source: ESSPROS, 2014

Table 3.: Receipts of social protection by type (as \% of total receipts) in 2012 


\begin{tabular}{|c|c|c|c|}
\hline Country & \% of GDP & $\begin{array}{c}\text { Euro per } \\
\text { Inhabitant }\end{array}$ & $\begin{array}{c}\text { In PPS per } \\
\text { Inhabitant }\end{array}$ \\
\hline Slovakia & 20,1 & 2639 & 4062 \\
\hline Czech Republic & 20,8 & 3033 & 4470 \\
\hline Hungary & 21,4 & 2093 & 3802 \\
\hline Poland & 17,5 & 1728 & 3252 \\
\hline Austria & 30,1 & 10965 & 9959 \\
\hline Germany & 31,8 & 10558 & 10503 \\
\hline France & 34 & 10568 & 9659 \\
\hline Romania & 15,9 & 1039 & 7946 \\
\hline United Kingdom & 30,7 & 9270 & 10161 \\
\hline Sweden & 32,2 & 13813 & 7894 \\
\hline Italy & 30,7 & 8083 & 5808 \\
\hline Spain & 24,9 & 5485 & 11816 \\
\hline Switzerland & 31,9 & 19598 & 9685 \\
\hline Finland & 33,4 & 11883 & \\
\hline
\end{tabular}

Source: ESSPROS, 2014

Table 4.: Receipts of social protection by type (as \% of GDP, in PPS per inhabitant) in 2012

However, if we look at empirical data we may observe many difficulties. In his research on civil society M. M. Howard (2003) presents empirical findings that constitute the crucial "baseline," a comparative measure of participation in voluntary organizations across a wide set of countries. The countries were divided into three groups, classified by prior regime type, as either "older democracies," "post-authoritarian," or "post-communist." The question phrasings were all identical, asking whether or not respondents are members of each of a set of nine voluntary organizations: (1) church or religious organizations, (2) sports or rec- 
reational clubs, (3) educational, cultural, or artistic organizations, (4) labour unions, (5) political parties or movements, (6) environmental organizations, (7) professional associations, (8) charity organizations, and (9) any other voluntary organization. The results show that, with the partial exception of labour unions, participation in voluntary organizations is much lower in post-communist countries than in the older democracies and the post-authoritarian countries. Compared to the two other groups, the post-communist countries are almost exclusively grouped at the lowest levels of organizational membership. Moreover levels of membership in post-communist countries have declined significantly, especially when compared to those in the post- authoritarian countries (Kállay et al., 2013). To summarize, we can say that the strongest actor in the field of social economy in terms of its capacity and economic size is the cooperative movement, which has strong tradition in Slovakia and identifies itself as a descendant of the early cooperatives in 19th century. It consists of successors of production cooperatives, commodity cooperatives, housing cooperatives and agricultural cooperatives since 1960s. They are associated in the Cooperative Union of Slovakia, which represents their voice towards the public and policy makers. However, the movement does identify itself with social economy and social enterprising (Strečanský - Stoláriková, 2012).

\section{Forms of NGO in Slovakia}

As already mentioned before, social economy designates the universe of practices and forms of mobilising economic resources towards the satisfaction of human needs that belong neither to for-profit enterprises, nor to the institutions of the state in the narrow sense (Moulaert - Ailenei, 2005). Social economy is made up of the voluntary, non-profit and co-operative sectors that are formally 
independent of the state. Legislation of these types of organizations in Slovakia is quite old. There are four main forms of NGOs in Slovakia:

- Civil Association

- Non-profit organizations

- Foundations

- Non-investment Funds

These forms are not regulated by one general legislation. All forms are partly regulated by Act 595/2003 on Taxes that defines particular process for "organizations established for non-profit activities".

Civil Associations are established by Act 83/1990 on Association of citizens. Civil association is understood as association of citizens, who intend to jointly promote common interests. Most common synonyms are: association, alliance, league and society, very often with the attribute "civil". Act N. 83/1990 ensures the citizens right to associate, stressing that nobody could be forced to associate. This act governs also trade unions, but doesn't govern number of members, internal authorities of association, their rights and responsibilities, economy issues like possibilities of incomes and extend of expenditures (for example extend of expenditures on operation of association) nor areas of acting. All these questions are leaved on members decisions. Thus the act could be identified as very flexible and tolerant. This brings both positive and negative consequences. As positive consequences we can identify simplicity of creation and operation of the association. Negative consequence could be variety of legal traps and obstacles that could be difficult to manage by the members. For example, in case of not correctly elaborated statute, association could easily lose the property or ability to operate. Process of registration is also quite simple; it requires only at least three persons (one of them must be adult) to establish the association. Registra- 
tion also requires statute of association that should consist of: Name of the association, residence of the association, area of operation, internal authorities and rules of their operation, rules of economy, internal control and its rules (Act 83/1990). Operation of the association is based on civil principles, so the main executive body is board of members. This authority could delegate responsibilities and rights to established internal authorities. There were tendencies to introduce new legislation on civil associations, but due to too restrictive nature of this novelisation it was not successful.

Non-profit organizations are regulated by Act. N. 213/1997 Coll. on NonProfit Organizations providing of generally beneficial services. Legislation regulates areas of operation that are: Health Care, Social Assistance and Humanitarian Aid, and others as shown at table 5. This extensive range illustrates that legislation aims to create a space for privatization of selected areas of public services. Internal bodies and coordination of operation creates a mixture located between foundations and non-investment funds. It is important to mentioned that if operating annually with more than $33.193 €$ (if donation of state, state institutions or local authority), or $165.969 €$ (total incomes), non-profit organisation is obliged to undertake external financial audit. Registration requires: Name and residence of the organization; area of operation; name, address and birth number of founder; name, address of director; financial and non-financial investments of founders if invested (Act 34/2002). 


\begin{tabular}{|c|c|c|}
\hline & Civil Association & $\begin{array}{l}\text { Non-Profit organization providing } \\
\text { of generally beneficial services }\end{array}$ \\
\hline Definition & $\begin{array}{l}\text { Legal body associating citi- } \\
\text { zens and/or legal bodies with } \\
\text { main aim to promote their } \\
\text { common interests }\end{array}$ & $\begin{array}{l}\text { Legal body providing of generally } \\
\text { beneficial services, which profit } \\
\text { could not be used for benefit of its } \\
\text { founders, members of internal Au- } \\
\text { thorities nor employees, but must be } \\
\text { used as a whole for providing of } \\
\text { generally beneficial services, espe- } \\
\text { cially for: } \\
\text { - Health care } \\
\text { - Social assistance and Humani- } \\
\text { - } \quad \text { Crian Aid } \\
\text { innovation, development, defence, } \\
\text { tellectual and cultural values } \\
\text { Defence of human rights and } \\
\text { basic values } \\
\text { Education, training and devel- } \\
\text { opment of physical culture } \\
\text { Research, development, scien- } \\
\text { tific and IT services } \\
\text { Creation and defence of Envi- } \\
\text { ronment and Public Health } \\
\text { Services for regional develop- } \\
\text { ment and employment } \\
\text { Housing, }\end{array}$ \\
\hline Registration & $\begin{array}{l}\text { Ministry of Interior of the } \\
\text { Slovak Republic }\end{array}$ & $\begin{array}{l}\text { Regional Office of Self-Governing } \\
\text { region }\end{array}$ \\
\hline $\begin{array}{l}\text { Establishing } \\
\text { document }\end{array}$ & Statute & $\begin{array}{l}\text { Establishing Charter (if established } \\
\text { by individual) or Establishing Con- } \\
\text { tract (if established by more persons) }\end{array}$ \\
\hline $\begin{array}{l}\text { Organizational } \\
\text { document }\end{array}$ & Statute & Statute \\
\hline Bodies & As defined in Statute & $\begin{array}{l}\text { Executive Board, Control Board and } \\
\text { other authorities as defined in Stat- } \\
\text { ute }\end{array}$ \\
\hline Act N. & $\begin{array}{l}\text { Act N. 83/1990 Coll. on Asso- } \\
\text { ciations of Citizens }\end{array}$ & $\begin{array}{l}\text { Act N. } 213 / 1997 \text { Coll. on Non- } \\
\text { Profit Organizations providing of } \\
\text { generally beneficial services }\end{array}$ \\
\hline
\end{tabular}




\begin{tabular}{|c|c|c|}
\hline & Foundation & Non-investment Fund \\
\hline Definition & $\begin{array}{l}\text { Purpose-built aggregation of } \\
\text { property that serves to support } \\
\text { generally beneficial aim. Gen- } \\
\text { erally beneficial aim is under- } \\
\text { stood mainly as: development } \\
\text { and defence of intellectual and } \\
\text { cultural values, realization and } \\
\text { defence of human rights and } \\
\text { other humanitarian aims, crea- } \\
\text { tion and defence of environ- } \\
\text { ment, health protection, child } \\
\text { protection and defence of right } \\
\text { of a child, development of } \\
\text { science, education and physi- } \\
\text { cal culture, realization of indi- } \\
\text { vidual humanitarian aid for an } \\
\text { individual or community in } \\
\text { risk }\end{array}$ & $\begin{array}{l}\text { Non-profit legal body that gathers } \\
\text { financial sources to provide of gen- } \\
\text { erally beneficial aim or individual } \\
\text { humanitarian aid for an individual } \\
\text { or community in risk of death or in } \\
\text { need of urgent assistance due to } \\
\text { natural disaster. Generally beneficial } \\
\text { aim is especially: development and } \\
\text { defence of intellectual and cultural } \\
\text { values, defence and support of } \\
\text { Health and education, development } \\
\text { of social services }\end{array}$ \\
\hline Registration & $\begin{array}{l}\text { Ministry of Interior of the } \\
\text { Slovak Republic }\end{array}$ & $\begin{array}{l}\text { Local authority office in place of } \\
\text { operating }\end{array}$ \\
\hline $\begin{array}{l}\text { Establishing } \\
\text { document }\end{array}$ & Foundation charter & Establishing Charter \\
\hline $\begin{array}{l}\text { Organizational } \\
\text { document }\end{array}$ & Foundation charter & Statute \\
\hline Bodies & $\begin{array}{l}\text { Executive Board, Administra- } \\
\text { tor of Foundation, Supervisory } \\
\text { Board and other authorities as } \\
\text { defined in Foundation charter }\end{array}$ & $\begin{array}{l}\text { Executive Board, Administrator } \\
\text { and other authorities as defined in } \\
\text { Statute }\end{array}$ \\
\hline Act $N$. & $\begin{array}{l}\text { Act N. 34/2002 Coll. on Foun- } \\
\text { dations }\end{array}$ & $\begin{array}{l}\text { Act N. 147/1997 Coll. on Non- } \\
\text { Investment Funds }\end{array}$ \\
\hline
\end{tabular}

Source: Holúbková, 2011

\section{Table 5.: Main forms of NGOs in Slovakia}

Foundations consist of financial property that is separated from property of foundation administrator legally, economically and in accounting. So we define it as capital fund serving generally beneficial issues. Primary property is $6.638 €$, consisting of financial or real estate property. Property over this amount could consist of other types. Registration requires: Name and residence of the organi- 
zation; area of operation; name, address and birth number of founder; name, address and birth number of administrator; value and items of primary property (Act 34/2002).

Non-Investment Fund is another type of association of property. This form is similar to Foundation, with some exceptions. Property on Non-Investment Fund consists only of financial property; there is no need for primary property. Operation expanses could not exceed $15 \%$ and supervisory board is not required. Registration requires: Name and residence of the Fund; identification number; area of operation; financial deposits of each founder; name of the bank and account number of founder; name and address of administrator (Act 147/1997).

\section{Current state of social economy in Slovakia (social enterprises, inclusive enterprises, intermediate labour market, etc.)}

Current social economy activities in Slovakia focus on two main areas: Employment and social services.

Activities in the area of unemployment are significant due to high level of unemployment in Slovakia. Currently level in September 2015 is 11,38\%, comparing to EU-28 - 9,3\%, which does not seems to be too much, but particular problem is long-term unemployment, especially very long-term unemployment as more than $66 \%$ of unemployed were out of job for more than one year and more than $50 \%$ over two years. Significant increase in number of people living in households with very low intensity of work (Bánovčinová et al., 2014) also has to be mentioned, especially due to risk of become unemployed.

International experience and evaluation of social enterprises varies considerably. In most countries, where social enterprises build on a longer tradition, these establishments - typically third sector organisations and organisations of a cooperative type - fulfil a variety of social missions (local and community develop- 
ment, social services provision, work integration of disadvantaged groups, etc.). There are several initiatives in civil society at present that promote and support the idea of social economy and development of social enterprising within the non-profits by developing their soft skills, business planning and enterprising skills (NeSST, UNDP, Integra Foundation or TriLobit association). Other segments of civil society act as participants in the field of social economy by selling mostly services, less products - social enterprises - but they do not stress this aspect of their work. These include various non-profit organizations that run schools, social housing, day-care centres for children or people with special needs and otherwise disadvantaged, protected sheltered workshops, educational organizations in the non-formal education or cultural associations. For example hospice care in Slovakia is provided only by third sector (non-profit organizations, civic associations or Catholic Church as the founders) with the very positive feedback from the clients on services (Dobrikova et al, 2014; Dobríková, 2010). Such non-profit organizations are strongly mission-driven and do not identify themselves as social entrepreneurs, although in last period this name becomes more popular. To some extent they use support provided by the state for employing persons with decreased working abilities, however, the size of their operations is local and community based. Because of the plurality of the third sector, initiatives that touch the concept provide great resource of experience (Strečanský - Stoláriková, 2012). Work-integration social enterprises are long established in several EU Member States 15 (Italy, Ireland, Belgium, Sweden), but usually they are not exclusively part of the Active Labour Market Policies (ALMP) scheme and in these terms not so generously subsidised as in Slovakia. The Law on employment services defined in 2008 a social enterprise as a legal or natural person with a workforce at least $30 \%$ of who were disadvantaged job seekers prior to this employment and obliged provider to re-invest at 
least $30 \%$ of the financial means gained through its activity and after deducted all eligible costs, towards creation of new jobs or to improvement of working conditions. The act established the right to a financial contribution towards creating and maintaining jobs for employees who were disadvantaged job seekers before being taken on. The Ministry of Labour, Family and Social Affairs covered the agenda of social economy. An important element has been also the European funding from the European Social Fund that provided support for this initiative. But social enterprises play a rather minor role in ALMP and even worst, As of August 2012 only 8 of 56 registered social enterprises were not-forprofit organizations or associations. The rest are limited companies or municipal public corporations and no cooperatives (Strečanský - Stoláriková, 2012). Audit in 2010 revealed that there were unauthorized procurements and purchases, suspicion of manipulated procurements and clientelistic behaviour of their managers related to the ruling political. Media widely reported about the misuse of these funds and the concept of social economy and social enterprise became associated with these misbehaving entities. Therefore the connotations of the concept among the Slovak general public have been since then negative and this affair has caused the negative perception of social economy (Lubecová, 2012). In view of the failure of pilot projects and the damaged reputation of the entire programme, new approaches had to be introduced.

Another field for social economy could be observed in realization of protected work-shops and protected work-places that are appointed to people living with disability (Act N. 5/2004). There were 7.508 of protected work-shops and protected work-places in Slovakia in 2014, providing of services for 13.325 citizens with disability. State supports each placement monthly and support depends on level of unemployment in each locality. Support vary from $4.500 €$ to $5.900 €$ and supported places has to be kept for at least 2 years. 
I would like to mention some of those new approaches that are:

- Extension of the activation activities

- Intermediate labour market

- Inclusive enterprises

Main principles of extension of the activation activities were introduced in 2009 and brought some new suggestions. Extension activities should be provided not only by the self-government region as before, but any business or natural entity (public services). Activities should be extended, for example to forestry activities, help in household, waste management, building maintenance and roads, security service, tourism, etc. Existing time limits should be cancelled $(6+12$ months). Also claims to the subsidies for the organizer (for example transport) should be extended, which will result to increase of the subsidy. The system should also cancel voluntary system that should lead to simplification of the system. Another positive effect should be higher competition of Employment Services by possibility of participation for non-public providers (Botek, 2014). This improvement proposal faced quite intensive criticism, stressing negative impacts of this proposal, like:

- Activation work is not based on regular contract - it is not building of real work competencies and is also not counted in pension system.

- Work is realized in place of living thus does not prepare for the open market, where travelling for work could be necessary.

- There is low motivation of provider to use this work-force efficiently, as the work-force is provided free.

- Work-time is limited, thus does not prepare workers for real open market, ect. 
Intermediate labour market should focus mainly on: Long-term unemployed citizen, who is recipient of the material need benefit and significantly disadvantaged citizen, who is recipient of the material need benefit and is based on following principles:

- Integration is performed by business entity or natural person (non-public employment services) on base of a project

- Reward to integrating entity dependent on success of integration on the labour market

- Integration is carried out 6 months

- Work for $80 \%$ of minimum wage - after 6 months transition to open market

Integration is based on:

- Activities, actions and services aimed at dismantling barriers that prevent entry and stay on the labour market - financial advice, integration plan, education

- Temporary employment on supported work place to obtain professional skills and practical experience (formalities, training or incorporation, supervision)

- Support in dealing with problematic situations in the workplace and beyond (6 months)

As already mentioned, inclusion to open labour market is for many of unemployed very difficult, especially for those unemployed for more than one year. One of possible solutions could be also Inclusive enterprise could be any enterprise that commit itself to employ at least $75 \%$ of all employees from target group (long term unemployed and other disadvantaged unemployed). Implementation is based on exclusively selected state contracts that do not provide of 
grants, but guarantee of orders only. Only full contracts are allowed, with maximum length of 2 years. After this period obtaining of job skills to apply on open labour market is expected. Separate market specific services has to be approved by the Commission and at least $80 \%$ of employer net profit has to be used for creation of new jobs, improving of work conditions or community benefits (Botek, 2014). Minimum of $70 \%$ of all expenses should be on wages.

As last I would like to mention field of social services as possible field for social economy. Ministry of Labour, Social Affairs and Family in collaboration with municipalities have realized SWOT analysis on providing of social services in 2007. The results of this analysis showed the urgent need of strengthening and encouraging of this area by the adoption of the new legislation. As a strongest site of social services is considered particularly the focus and effectiveness of the social services providing after the decentralization, also the respect for the principle of the subsidiarity and strengthened financing under the new tax redistribution mechanism. According to the Act No. 448/2008 Coll. on social services as amended public and non-public providers are obliged for registration to provide social services and specialised activities (Kállay et al., 2013). Social services in Slovakia are ensured by municipalities. Municipalities may prefer to choose those providers which it had established (both public and non-public). If services cannot be provided by public providers, municipalities could buy those services from non-public providers. Those practices have been criticised by nonpublic providers who complain about imminent discrimination against them. The clients' right of free choice of facility also is jeopardized. Up to the first half of 2011 there were totally of 2742 registrations for providing of social services and specialised activities in the Central Register of social service providers (the figure was higher than total number of providers because of one provider could be 
registered for various services and activities according the Act on social services).

- Almost $3 / 4$ of all registrations $(73,5 \%)$ were connected to social services for long-term care dependent persons (mainly to provide home care, services of care homes or homes for seniors).

- In Bratislava and Košice regions number of registrations referred to a number of people as potential social service users was the highest, in Prešov region, in opposite, the lowest.

- Almost $62 \%$ of all registrations were as registrations of public providers, $38 \%$ were as registrations of non-public providers.

- The highest amount of public service providers s registrations were focused on area of long-term care services $(66,5 \%)$ and supportive services $(80 \%)$ that belongs to a traditional social service engagements of local and regional governments.

- Number of registrations of public and non-public providers in other social service areas (e.g. ensuring of basic living needs, family and children support) was more balanced/equalised; in a case of new types of social services (e.g. low-threshold centres, services based on ICT solutions) or some specialised activities (e.g. social counselling, social rehabilitation) the representation of non-public providers was clearly higher.

- To ensure an integrated social - health long-term care for care dependent persons totally for 14 hospitals were registered as social service providers. In totally eight cases they were as non-profit organisations, mainly from Prešov a Košice regions.

- There was some general observation that traditional types of social services (e.g. home care, homes for seniors, residential care homes) were 
dominated by public service providers while new types of them were as a dominance of non-public ones (Kállay et al., 2013).

\section{Conclusion}

Social economy in Slovakia is still relatively new phenomenon (even in deeper historical context not really) that is undertaking slow development due to different reasons, mentioned above. In spite of it the need for efficient social economy is recognized by all actors and the legislation slowly develops toward better conditions. Opinions on how to make it more efficient vary, but the trend is clear even due to European trends that should affect join vision of future development of social economy in Slovakia. 


\section{References:}

Bánovčinová, A., Levická, J. \& Vereš, M. (2014): The Impact of Poverty on the Family System Functioning. Procedia - Social and Behavioral Sciences 132(2014) 148-153. DOI:10.1016/j.sbspro.2014.04.291

Botek, O. (2009): Sociálna politika pre sociálnych pracovníkov. Pieštany: PN Print. ISBN 978-80-970240-0-0

Botek, O. (2014): 20 Years of Transformation of Social Policy in Slovakia. Procedia - Social and Behavioral Sciences 08/2014; 143. DOI:10.1016/j.sbspro.2014.07.489

Brown, P. L. (1997): The two faces of the social economy. Paper presented at the Eighth Conference of Canadian Welfare Policy, University of Regina, Saskatchewan, June 1997

Dobríková, P. (2010): Quality of Life in Incurable Patients. In Studia Psychologica. ISSN 0039-3320, 2010, 52, 2, p. 155-163.

Dobrikova, P.,Pcolkova, D., AlTurabi, L. K. \& West, D. (2014): The Effect of Social Support and Meaning of Life on the Quality of Life Care for Terminally Ill Patients. In: American Journal of Hospices \& Palliative Medicine. SAGE Publication, DOI: 10.1177/1049909114546208

Dudeková, G.: Dobrovol'né združovanie na Slovensku $v$ minulosti. http://www.dejiny.sk/eknihy/gd.htm, 15.10.2015 
ESSPROS - Expenditure and receipts on Social Protection and number of Pension Beneficiares in 2012 (2014) Statistical Office of the Slovak Republic. Bratislava ISBN 978-80-8121-321-2

Holúbková, T. (2011): Legal framework of the governance of non-profit NGOs in Slovakia. http://emi.mvso.cz/EMI/2011-01/05\%20Holubkova/Holubkova.pdf. 10.10 .2015

Howard, M.M. (2013): The weakness of civil society in post-communist Europe. Cambridge, University Press, 2003, Cambridge, United Kingdom,. ISBN 0-521$81223-2$

Kállay, A., Slaná, M., Botek, O., Vereš, M. \& Pavelek, L. (2013): Social Inclusion in Connection with Civil Society. ERIS Web Journal, Volume 4, Issue 2, 2013 ISSN 1804-0454

Laville, J.-L. \& Delfau, G. (2000): Aux sources de l'e'conomie solidaire. Domont: Ed. Thierry Quinqueton.

Leyshon, A., Lee, R. \& Williams, C. C. (Eds) (2003): Alternative Economic Spaces. London: Sage.

Lévesque, B., Malo, M.,C. \& Girard, J.,P. (1999): L'ancienne et la nouvelle e'conomie sociale, in: Defourny, J. - Develtere, P. - Fonteneau, B. (Eds) L'e'conomie sociale au Nord et au Sud, pp. 195-216. Paris: De Boeck\&Larcier.

Lubelcová, G. (2012): Sociálna ekonomika: koncepty, príležitosti, riziká. Sociológia 44 (1): 83-107 
Moulaert, F. \& Ailenei, O. (2005): Social Economy, Third Sector and Solidarity Relations: A Conceptual Synthesis from History to Present. In: Urban Studies, Vol. 42, No. 11, 2037-2053, October 2005

Mydlíková, E.: Sociálna práca v neziskovom sektore. Habilitation thesis. University of st. Elisabeth. Bratislava 2009

Nižňanský, V.: Decentralizácia na Slovensku. Úrad vlády SR, Bratislava 2005

Ondrušek, D. \& Matijek, G. (2000): Treti sektor a tretí sektor. In: Čítanka pre pokročilé neziskové organizácie. Bratislava: PDCS 2000 ISBN 80-968095-3-9

Pavelek, L. (2014): Current Problems of Social Capital, Civil Society and Subjective Well-Being in Slovak Republic. World Applied Sciences Journal 31 (3): 383-389, 2014. ISSN 1818-4952

Salamon, L. M. \& Anheier H. K. (1995): The Emerging Sector: The Nonprofit Sector in Comparative Perspective. Overview. Baltimore, MD: Johns Hopkins University.

Sociálna politika V Slovenskej republike V roku 2001. (2002) Bratislava: MPSVR SR

Strečanský, B. \& Stoláriková, K. (2012): Social economy and social enterprises in

Slovakia.

http://www.cpf.sk/files/files/Pages $\% 20$ from $\% 20$ CivSzle 20124 web.pdf. 10.10.2015

Tomeš, I. (2010): Úvod do teorie a metodologie sociální politiky. Praha: Portál 


\section{Legislation:}

- $\quad$ Act N. 5/2004 Coll. On Employment Services

- $\quad$ Act N. 83/1990 Coll. on Associations of Citizens

- $\quad$ Act N. 34/2002 Coll. on Foundations

- $\quad$ Act N. 147/1997 Coll. on Non-Investment Funds

- Act N. 213/1997 Coll. on Non-Profit Organizations providing of generally beneficial services

- $\quad$ Act N. 448/2008 Coll. On Social Services 


\section{Social Economy in the Czech Republic}

\section{Š́rka Ulčáková}

The development of social economy in the Czech Republic is similar to the developments in other countries of Europe, which is connected to the changes in society in the context of its modernization. In recent decades, this phenomenon has led to the emergence of new social problems that had not been known in the past and to the deepening of the "old" social problems as well. However, the reaction of the welfare state to those new conditions has not been adequate and did not provide the solutions. It did not react to the higher demand for services and protection by providing more services and better protection, instead the secondary bonds of protection have gradually been reduced. While the normalization period in the history of the Czech Republic (and other postcommunist countries) was characterized by colonization of private by public, recent years can be characterized by the colonization of public by private. In constant afford to catch up with the development of Western Europe, especially in the field of economy, Czech government began to take action leading to the reduction of resources spent on the welfare state. This is connected to the privatization of the services that used to be public just until few years ago. As a consequence, potential space for organizations that would be complementary to the remaining services and protection of the welfare state has grown. Social economy in its contemporary meaning is therefore getting more and more attention in the Czech Republic, where it is slowly, but surely getting support from the government, professional public and in the field of legislation as well. It is also important to mention that European Union and some international organizations and funds support has played an important role in the development 
of social economy from the ideological and financial point of view and helped to establish many social economy entities and implement projects in this field.

\section{History of Czech social economy and social entrepreneurship}

The origins of social entrepreneurship in the Czech Republic can be traced back to the 19th century, especially in the connection to the rich associational and cooperative traditions in this country. František Cyril Kampelík, František Ladislav Chleborad or Karel Engliš were among those who have influenced the development in this area with ideas very similar to the principles of social economy and social entrepreneurship as we know them today. František Cyril Kampelík promoted the equity business and self-help as means of serving the development of industry and entrepreneurship, contributed to the formation of general insurance companies and compulsory property insurance and also supported the establishment of credit unions. František Ladislav Chleborad played an important role in the process of establishment of self-supporting societies like for example manufacturing and consumer associations of laborers. His ideal was a cooperative business and one of his thought was that the goal of economic activity should not be to acquire assets. Also Karel Engliš saw the meaning of economic in something else than profit only - he thought the goal should be to care about the maintaining and improving lives. Among other personalities who have influenced the development of social economy in The First Republic (1918-1938), was Tomáš Garrigue Masaryk who promoted fairness, reciprocity and philanthropy. ${ }^{1}$

\footnotetext{
${ }^{1}$ DOHNALOVÁ, Marie, PRŮŠA, Ladislav a kol., Sociální ekonomika. 1st ed. Praha: Wolters Kluwer ČR, 2011, ISBN 978-80-7357-573-1.
} 
There is a long tradition of mutual societies and cooperatives connected to the development of Czech small and medium-sized entrepreneurship in the second half of 19th century. In 1873 cooperatives were defined by law as "an association of persons for joint economic activity, pursuing the goal to support the earnings or economic activities of its members and thus improving and increasing the level of their material well-being." ${ }^{2}$ Entrepreneurs at that time had to face problems with financing their activities, which was connected to the absence of Czech banks that would provide them a loan. As a solution, those entrepreneurs have established self-help credit unions. Most important role in the history of Czech cooperatives at the beginning of 20th century had the central union of Czechoslovak production cooperatives which was established in $1908 .^{3}$ However, most of cooperatives have been established between the two world wars when there was no functional central office for those organizations. The Central Council of Cooperatives which was established in 1945 was supposed to solve this situation. However, the new regime changed the conditions for those organizations since communist ideology suppressed some of their most important principles, such as the voluntariness, autonomy and self-government. Small producers and entrepreneurs were forced into the collectivization and the remaining authentic cooperatives were constantly harmed by the regime and their activities were restricted. Despite those circumstances, cooperatives preserved the independence at least to a certain degree together with some other principles. ${ }^{4}$ Since the revolution in 1989 , the cooperatives have again been able

2 DOHNALOVÁ, Marie, PRŮŠA, Ladislav a kol., Sociální ekonomika. 1st ed. Praha: Wolters Kluwer ČR, 2011, s.46, 176 s., ISBN 978-80-7357-573-1.

3 DOHNALOVÁ, Marie, PRŮŠA, Ladislav a kol., Sociální ekonomika. 1st ed. Praha: Wolters Kluwer ČR, 2011, 176 s., ISBN 978-80-7357-573-1.

${ }^{4}$ GUTH, Jiří a kol. Družstevnictví v kostce. Alternativa zdola: Občanská iniciativa za zodpovédnou budoucnost [online]. [cit. 2015-12-12]. Available at: http://alternativazdola.cz/liferay/documents/187913/3867632/Dru\%C5\%BEstevnictv\% 
to implement all their original principles into practice. This include the principle of open and voluntary membership, democratic control, economic participation, autonomy and independence, education, training and information, cooperation among cooperatives and responsibility for society. ${ }^{5}$

Historical development of other associative organizations in the Czech Republic was similar. Around 1935, many humanitarian and supporting associations have been established, later on followed by the establishment of other organizations that were supposed to mitigate the consequences of war. In next years, social economy played an important role in the society, although the conditions for the practice of its entities were always very influenced by the actual situation in the politics and economy of the state. This also applies for 1948, when the idea that "the construction of society also by civil and self-help organizations is not desirable" 6 gradually began to be enforced, which led to abolishing many humanitarian and supporting associations or their conversion to "social organizations".

The nationalization influenced also the joint-stock and insurance companies which had to cease their activities. In 1953, the Constitutive Congress of the Central Union of Production Cooperatives was held on which it was decided to create the long-term loan fund which should had been used to finance "expanded reproduction of basic means". 7 During the process of normalization in 70's, associational life was controlled. Until 1989, publicly and politically active

C3\%AD_v_kostce-Ji\%C5\%99\%C3\%AD+Guth_a_kol+.pdf/709062a3-ef6a-4846acab-b62c $3 \mathrm{c} 5 \mathrm{f} 5 \mathrm{c} 2 \mathrm{c}$

${ }^{5}$ DOHNALOVÁ, Marie, PRŮŠA, Ladislav a kol., Sociálni ekonomika. 1st ed. Praha: Wolters Kluwer ČR, 2011, p.52, ISBN 978-80-7357-573-1.

6 DOHNALOVÁ, Marie, PRŮŠA, Ladislav a kol., Sociální ekonomika. 1st ed. Praha: Wolters Kluwer ČR, 2011, str.48, 176 s., ISBN 978-80-7357-573-1.

7 DOHNALOVÁ, Marie, PRŮŠA, Ladislav a kol., Sociální ekonomika. 1st ed. Praha: Wolters Kluwer ČR, 2011, str.48, 176 s., ISBN 978-80-7357-573-1. 
organizations could operate only if they were part of the National Front. The associational and foundation activities have been renewed after the revolution and new forms of social economy entities have been established. New Law No. 83/1990 Coll. about the association of citizens, Law No. 248/1995 Coll. about public benefit corporations, Law No. 227/1997 Coll. about foundations and foundation funds or the Law No.3/2002 Coll. about churches and religious societies have been introduced. ${ }^{8}$

The development of social economy in the Czech Republic after 2000 has been influenced by the rising awareness about social entrepreneurship, which was connected to the establishment of new small enterprises, working groups, networks or pilot projects supported from EU and foreign foundations. ${ }^{9}$ The topic of social economy is gradually getting more attention recently. The important step towards the recognition of the concept was the announcement of several calls by the Ministry of Labour and Social Affairs focused on the creation of new entrepreneurial activities. Many activities connected to the social entrepreneurship in the Czech Republic was also supported by the CIP EQUAL program funded by the European Union. This program led to an effort to define crucial terms in this field, such as "social economy", "social entrepreneurship" or "social enterprise", and helped to clarify the principles of social economy and social entrepreneurship.

${ }^{8}$ DOHNALOVÁ, Marie, PRŮŠA, Ladislav a kol., Sociální ekonomika. 1st ed. Praha: Wolters Kluwer ČR, 2011, ISBN 978-80-7357-573-1.

9 BEDNÁRIKOVÁ, Daniela a Petra FRANCOVÁ. Studie infrastruktury sociální ekonomiky ČR: plná verze. 1st ed. Praha: Nová ekonomika, 2011, ISBN: 978-80-2600934-4. 


\section{Definitions of social economy}

However, just like in many other countries in Europe, there are several different definitions which are very general. This means two consequences - the positive one is that there are not many strict borders yet which means more freedom for organizations operating in this field and might be important in the process of the development of such a complex concept, the negative consequence is that the absence of overarching consensus on the definitions might cause confusions and lead to the creation of barriers in the practice of social economy entities (for example in connection to the creation of supportive legislation or in the area of research etc.).

As has been mentioned before, one of the definitions of social economy has been introduced by representatives of non-profit organizations, cooperatives and professional public as one of the outputs of NTS C CIP EQUAL project. The definition is derived from the Anglo-Saxon concept which puts more emphasis on entrepreneurship, and the southern approach which emphasizes mutuality and self-help. According to this definition, social economy is ,a complex of autonomous private activities implemented by different types of organizations, which are aimed at serving their members and the local community - above all through enterprise. Social economy is oriented towards addressing the issues of unemployment, social cohesion and local development. It forms and develops based on the concept of triple bottom line - economic, social and environmental benefits. Social economy allows citizens to get actively involved in regional development. While generating profit/surplus is desirable, it is not the primary goal. Any profit is used in preference for developing the organization's activities of for the needs of the local community. Internal relations in social enterprises are oriented towards the maximum involvement of members/employees in 
decision-making and towards self-management, while external relations strengthen social capital. The legal form of social economy entities is not decisive - what is crucial is that they pursue publicly beneficial objectives that are listed in their statutes. Social economy entities include social enterprises and organizations that support their activities in the areas of education, consulting and financing“ 10

There are also other definitions, such as the definition used by Jaroslava Syrovátková in which social economy aims at solving issues of unemployment, social cohesion and local development, and derives from economic, social and environmental development, which "enables an active involvement of each citizen into the development of the region." 11 According to this definition, first aim of social economy is not to create a profit, however, in case of profit this should be used for further development of the activities of the organization or for the community. However, the most important goals are those that have been set by the organization itself.

In the professional literature, many authors prefer to define social economy entities rather than social economy itself. In this case, there are two basic approaches to the definitions - normative and legal-institutional. As for the normative approach, many definitions of Czech authors are derived from foreign resources such as the general definition in the Social Economy Charter. Jacques

\footnotetext{
${ }^{10}$ Czech baseline study on Social Economy: Preliminary statement. Ministry of Labour and Social Affairs, Czech Republic, 2009 [online]. Available at: http://wayback.webarchiv.cz/wayback/20121026152315/http://www.socialniekonomika.cz/images/Pdf/Czech_baseline_study_on_Social_Economy_fin.pdf

${ }^{11}$ SYROVÁTKOVÁ, Jaroslava. Sociální podnikání. 1st ed. Liberec: Technická univerzita v Liberci, 2010, p.17, ISBN: 978-80-7372-683-6
} 
Defourny and Carlo Borzaga are also often cited with the following definition of social economy entities: „Social economy includes economic activities carried out by co-operatives and related enterprises, mutual societies and associations whose ethical stance is represented by the following principles:

- $\quad$ The aim of serving members or the community, rather than generating profit;

- An independent management;

- A democratic decision making process;

- $\quad$ The primacy of people and labour over capital in the distribution of income. ${ }^{\text {(12 }}$

Within an infrastructure study which has been conducted by TESSEA ${ }^{13}$ in 2011, social economy was defined as "a summary of activities carried out by social economy entities, whose goal is to increase employment within local conditions or to meet other needs and goals of the community in the area of economic, social, cultural and environmental development." 14

\footnotetext{
${ }^{12}$ The emergence of social enterprise. London: Routledge, 2004. Routledge studies in the management of voluntary and non-profit organizations. p. 6, ISBN 0-415-33921-9.

${ }^{13}$ Thematic network which associates individuals, entrepreneurs, non-profit organizations, universities and other institutions which seek to raise awareness of social economy among lay and professional public. TESSEA also supports the creation of tools and infrastructure for the development of social economy. More at http://www.ceskesocialni-podnikani.cz/cz/tessea

${ }^{14}$ Sociální ekonomika a NNO v ČR, Centrum pro komunitní práci [online], Centrum pro výzkum neziskového sektoru pro Nadaci rozvoje občanské společnosti, 2005, p.14. [Citace: 8. března 2013]. Available at: www.cpkp.cz/regiony/file_download/215
} 
Dohnalová $^{15}$ claims that social economy entities are oriented on solving the issues connected with unemployment, social cohesion or local development, and their activities are based on the concept of triple bottom line. The same author also highlights the principles of social economy entities that were introduced on the International Conference on Problems of Propagation of Social Economy which was held in Prague in 2002. Those are:

1. „Establishments of social economy have already been inscribed in the given locality. They establish relations with local authorities. They are, most often, who assures economy in agricultural areas including the ones affected by difficulties. All establishments of social economy are the most important actors on the scene of the local and regional development.

2. Establishments of social economy prefers integration. They set as their goal to avert exclusion of persons and, on the contrary, to facilitate integration or protection of their members and employees, including those most disadvantaged, without any form of discrimination. Another goal is the support of solidarity. As they do not exercise the policy of selection (of members, employees) cooperatives succeed in reducing social risks. Besides that these organizations bestow considerable financial means for the education of their members and employees.

3. Intergenerational solidarity is one of the attributes of establishments of social economy. They build up indivisible reserves, organize social protection based on mutuality of risks and sources. Non-profit character and democratic management are common features of these systems.

\footnotetext{
${ }^{15}$ DOHNALOVÁ, Marie, PRŮŠA, Ladislav a kol., Sociální ekonomika. 1st ed. Praha: Wolters Kluwer ČR, 2011, 176 s., ISBN 978-80-7357-573-1.
} 
They contribute to the construction of a social Europe by way of their active participation in social and civic dialogue.

4. Functioning of establishments of social economy approaches to the concept of social responsibility and their values and practices are very close to what the Commission wants to promote as the values that are defending the European Union alone, i.e. the values tied to social responsibility and continuous growth: participation of employees and users, solidarity, personal development. Rendering service to citizens within the frame of collective approach is considered priority. “16

As for the legal-institutional approach to the definition of social economy entities, one example is a definition introduced by TESSEA. Social economy entities are here described as "supporting, financial, counseling and educational institutions for social entrepreneurship and non-profit organizations, which conduct economic activities aiming at the employment of their clients or additional funding for their missions. Social economy entities share common values, which are - meeting the "public benefit goal", democratic decision making, promotion of citizens' initiative, independence from public and private institutions, a different way how to deal with profit, attention paid to the environmental aspects, meeting local needs and using local resources preferentially." 17

In practice, social economy entities are led by entrepreneurs with trade license or can have a legal form of a business company, such as limited liability companies

${ }^{16}$ Summary Information and Conclusions of International Conference on Problems of Propagation of Social Economy. CECOP-EST [online]. 2002 [cit. 2015-12-14]. Available at: http://www.cecop-est.cz/conference.html

${ }^{17}$ Sociální ekonomika a NNO v ČR, Centrum pro komunitní práci [online], Centrum pro výzkum neziskového sektoru pro Nadaci rozvoje občanské společnosti, 2005, p.14. [Citace: 8. března 2013]. Available at: www.cpkp.cz/regiony/file_download/215 
or cooperatives (in 2014 a new legal form of social cooperative has been introduced), but also organizations with legal forms used most often by nonprofit organizations, such as "generally beneficial companies" or civic associations. ${ }^{18}$ Marie Dohnalová ${ }^{19}$ argues that social enterprises can take a form of civic associations, registered legal entities - church institutions, "generally beneficial companies" and foundations and foundation funds which employ disadvantaged people or conduct economic activity as an additional activity.

\section{Current situation of social economy in the Czech Republic}

As has been already mentioned above, social economy has recently become frequently discussed topic in the Czech Republic and is gaining attention among professional public, academics, and politicians as well. The government has recognized the concept of social entrepreneurship, which is apparent from the changes in legislation and further affords in this area (for example the new law on social cooperatives or the law on social enterprises which is currently in the preparation stage), but also from the new calls for social entrepreneurs, such as the Call No.11 Social Entrepreneurship for socially excluded areas or the Call No. 12 Social Entrepreneurship. The development in this area is especially visible when we look at a literature resources and reports from the past. For example Hunčová characterized the state of the perception of social economy by the government and public authorities in 2008 as followed: "Due to the possibility to draw support from European social funds, there is a new attention paid to social

\footnotetext{
${ }^{18}$ Sociální ekonomika a NNO v ČR, Centrum pro komunitní práci [online], Centrum pro výzkum neziskového sektoru pro Nadaci rozvoje občanské společnosti, 2005 [Citace: 8. března 2013]. Available at: www.cpkp.cz/regiony/file_download/215

${ }^{19}$ DOHNALOVÁ, Marie et al. Sociální ekonomika - vybrané otázky. 1st ed. Praha: VÚPSV, 2009. ISBN 978-80-7416-052-3.
} 
economy, also by some of the public authorities... however not yet by the politicians. The topic of social economy has therefore been implemented into the National Development Plan for the Czech Republic for 2007-2013, however implementation into the operational programs is still problematic. Only in 2008, it seems that the legal framework, which has been very unresponsive so far, might begin to change." 20

As for the organizations that are operating in the area of social economy in the Czech Republic, one of the first organizations promoting social economy was civic association ORFEUS which primarily focuses on activities supporting people with disabilities. It is an association which has established a working group consisted of representatives from theoretical departments, non-profit sector and municipalities already in 2004. ORFEUS also published a book called Social Economy in the European Union and Its Application to the Conditions in Czech Republic. ${ }^{21}$

Another organization in this area is Civil Society Development Foundation which is focused on the promotion of organizations of civil society, based on funding, connecting and reconciling the interests, education or professional organization of the society or individuals. The foundation is especially paying attention to projects which "help vulnerable and disadvantaged groups, support human rights and democratic values, contribute to mutual coexistence and toler-

\footnotetext{
${ }^{20}$ HUNČOVÁ, Magdalena. Sociální ekonomika a sociální podnik v teorii a praxi. Bruntál: Moravská expedice, 2008, p.18, ISBN: 80-86511-31-6.

${ }^{21}$ Sociální ekonomika: výzkumná zpráva nadnárodního partnerství Social Enterprise. Praha: Orfeus, 2008, p.5, ISBN: 978-80-903519-5-0.
} 
ance of minorities in society or "revive" the interest of citizens in the local development and public life in any other way." 22

An important organization in recent development of social economy plays P3 People, Planet, Profit, o.p.s. (“generally beneficial company"), which promotes and supports social entrepreneurship in the Czech Republic, provides counseling, organizes seminars and workshops, administers the website www.ceske-socialni-podnikani.cz (which according to P3 is the largest resource of information about social entrepreneurship in the Czech Republic) and coordinates the thematic network for social economy TESSEA. ${ }^{23}$

${ }^{22}$ Nadace rozvoje občanské společnosti, Nadace rozvoje lidské společnosti [online]. [Cit. 2013-03-09]. Available at: http://www.nros.cz/cs/o-nadaci/

${ }^{23} \mathrm{P} 3$ - People, Planet, Profit, o.p.s. České sociální podnikání [online]. [cit. 2015-12-13]. Available at: http://www.ceske-socialni-podnikani.cz/cz/kdo-jsme/p3 


\section{References}

Bednáriková, D. \& Francová, P. (2011): Studie infrastruktury sociální ekonomiky ČR: plná verze. 1st edition. Praha: Nová ekonomika, ISBN: 978-80260-0934-4

Czech baseline study on Social Economy: Preliminary statement. Ministry of Labour and Social Affairs, Czech Republic, 2009 [online]. Available at:

http://wayback.webarchiv.cz/wayback/20121026152315/http://www.socialniekonomika.cz/images/Pdf/Czech baseline_study_on_Social_Economy_fin.pdf

Dohnalová, M. et al., (2009): Sociální ekonomika - vybrané otázky. 1st edition. Praha: VÚPSV, 2009, ISBN 978-80-7416-052-3.

Dohnalová, M. \& Prǔša, L. a kol., (2011): Sociálni ekonomika. 1st edition. Praha: Wolters Kluwer ČR, ISBN 978-80-7357-573-1.

Guth, J. a kol. Družstevnictví v kostce. Alternativa zdola: Občanská iniciativa za zodpovědnou budoucnost [online]. [cit. 2015-12-12]. Available at: http://alternativazdola.cz/liferay/documents/187913/3867632/Dru\%C5\%BEstev nictv\%C3\%AD_v_kostce-Ji\%C5\%99\%C3\%AD+Guth_a_kol+.pdf/709062a3ef6a-4846-acab-b62c3c5f5c2c

Hunćová, M. (2008): Sociální ekonomika a sociální podnik v teorii a praxi. Bruntál: Moravská expedice, 2008, ISBN: 80-86511-31-6.

Nadace rozvoje občanské společnosti, Nadace rozvoje lidské společnosti [online]. [Cit. 2013-03-09]. Available at: http://www.nros.cz/cs/o-nadaci/ 
P3 - People, Planet, Profit, o.p.s. České sociálni podnikání [online]. [cit. 201512-13]. Available at: http://www.ceske-socialni-podnikani.cz/cz/kdo-jsme/p3

Posláni Nové ekonomiky, Nová ekonomika [online]. [Cit. 2013-03-09]. Available at: http://wayback.webarchiv.cz/wayback/20121026151516/http://www.socialniekonomika.cz/cs o-nas.html

Sociální ekonomika: výzkumná zpráva nadnárodniho partnerství Social Enterprise. Praha: Orfeus, 2008, ISBN: 978-80-903519-5-0.

Sociální ekonomika a NNO v ČR, Centrum pro komunitní práci [online], Centrum pro výzkum neziskového sektoru pro Nadaci rozvoje občanské společnosti, 2005, [Cit. 2013-06-08]. Available at: www.cpkp.cz/regiony/file download/215

Syrovátková, J. (2010): Sociální podnikání. 1. vyd. Liberec: Technická univerzita v Liberci, ISBN: 978-80-7372-683-6

The emergence of social enterprise. London: Routledge, 2004. Routledge studies in the management of voluntary and non-profit organizations. ISBN 0-41533921-9. 


\section{Social Enterprise in the Czech Republic}

\section{Šárka Dořičáková}

Why should one's business be a social enterprise? - This is a frequently asked question. Today, we often struggle with the problem of labour market deformation and this is the reason why we look for ways to meaningful employment activities for workers. Due to persistent unemployment, we have to deal with more and more social problems and this leads to higher expenditures on unemployment benefits from the State Budget. Social enterprise organisations try to engage people in the employment process and at the same time, they try to minimize their financial dependence on society. They create an offer of goods and services which are in harmony with a friendly approach to the environment. This non-traditional form of enterprise is a way of employing disabled people or people who are socially or culturally disadvantaged. The objective of social enterprise is to remove the barriers that prevent some people from entering the free labour market and thus to contribute to better concordance between the supply of labour force and the demand for it and its qualifications.

The Czech interpretation of the definition of social enterprise: "Social enterprise means entrepreneurial activities which benefit society and the environment. Social enterprise plays an important role in local development and often creates employment opportunities for people with disabilities or for the socially or culturally disadvantaged. The major part of profit is used for the further development of the social enterprise. For a social enterprise, it is just as important to make profit as it is to increase public well-being”. (České sociální podnikání \{Czech Social Enterprise\}, 2015). 
The word "social" in social enterprise is often misunderstood and some people may associate it with incorrect things. This word tends to mislead people into thinking that social enterprise is a beneficent, charitable activity that is supported by the state or other donors. However, social enterprise means entrepreneurial activities based on the three pillars of social responsibility and the aim of social enterprise is achieving profit as well as benefiting society, while subsidies are seen as the last resort. The most important aspect of social enterprise is the rearrangement of life's values and attitudes to society. Social enterprises give work to employees and pay them wages for their work.

\section{Social enterprise}

A social enterprise is a competitive entrepreneurial entity that operates on the usual market with the aim to create employment opportunities for persons who are at a disadvantage on the labour market and to provide such people with suitable occupational and psycho-social support. It may be a corporate entity as well as a natural person that conforms to the principles of social enterprise and its socially beneficial goals are specified in its memorandum of association or in similar documents. Social enterprises may be divided into integration, general and environmental.

If an entity claims to have the status of a social enterprise, it must comply with all of the principles of social enterprise. This means that not every employer who claims to be a social enterprise really is one. Even socially responsible companies do not have to be social enterprises, as they are established to make profit. And even companies where more than $50 \%$ of their workforce are people with disabilities do not automatically count as integration social enterprises if they do not conform to all of the principles. This means that a socially therapeutic work- 
place which provides social services to its clients is not a social enterprise either, as it does not provide employment (Kurková, Francová and Bednáriková, 2015). The aim of social enterprise is the development of new economic activities and good-quality services at a local level, which enables higher employment and better quality of human life. Social enterprises create new jobs for those groups of the population which are most at risk on the labour market. These jobs are often interconnected with development of services and production of innovative goods. Services of social enterprises are most often provided by small entrepreneurs, but also by non-profit organisations as their secondary activities. However, at present, for-profit social enterprises are supported, i.e. enterprises established for the purpose of entrepreneurial activity under Act no. 90/2012 Sb. ${ }^{1}$, On Corporations and Cooperatives (The Act on Corporations).

The basic difference between the entrepreneurial activities of a social enterprise and other types of businesses is the precondition that it complies with the principles of social enterprise. An integration social enterprise is a sustainable entrepreneurial entity which creates employment opportunities for at least $30 \%$ of employees who are socially disadvantaged out of the total number of employees and which places emphasis on respecting the health condition, or specific social situation, of each employee. Social enterprises have multiple sources of funding with their main income derived from their own activities but they may also use funds from public sources to compensate for the lower productivity of their employees. Further income may come from donations or volunteering. People who are establishing a social enterprise, unlike in the case of those who are starting an ordinary business, must be aware that sufficient funds need to be invested for instance into adjustments of the workplace or into educating employees about the specifics of social enterprises.

\footnotetext{
${ }^{I}$ Translator's note: Sb. - Collection of Laws of the Czech Republic
} 
In the Czech Republic, social enterprises are organisations which are established both under Civil Law and under Business Law, set up by private entities (natural and artificial persons) as well as public ones, or in mixed ownership. So there exists a significant diversity in the legal forms of entities - from sole traders to co-operatives to church organisations which do business as their secondary activity, to voluntary associations of municipalities which are formed by three municipalities none of which has the majority of decision-making rights. This may include entities which are highly internally structured, divided into specialised part and units with clearly separated tasks. Today, there are 217 companies that claim to be social enterprises in the Czech Republic. (České sociální podnikání \{Czech Social Enterprise\}, 2015).

\section{The principles of a social enterprise}

The first principles applying to social enterprises were defined and approved by TESSEA $^{2}$ in September 2010. These were later taken over by the Ministry of Labour and Social Affairs of the Czech Republic and incorporated into the Ministry's calls in the area of social economy in order to define a social enterprise. They were also used by Česká spořitelna in its pilot programme of microloans for social enterprises. (Bednáriková and Francová, 2011, pp 14-15)

\footnotetext{
${ }^{2}$ Translator's note: TESSEA (established in 2009) is a thematic network for social economy that associates individuals, entrepreneurs, NGO's, non-profits, universities and other institutions with the aim to promote social economy and social enterprise (source - Tessea website in the Czech language: http://ceske-socialni-podnikani.cz/cz/tessea on Dec. 28, 2015, translated from Czech by translator)
} 
The principles of an integration social enterprise:

1. Social Benefit

a) Employment and social inclusion of persons disadvantaged on the labour market,

b) employees and members participate in decisions as to the direction where the company is heading,

c) emphasis on the development of occupational competences of disadvantaged employees.

2. Economic Benefit

a) possible profit is preferentially used for the development of the social enterprise and/or for achieving aims which benefit the community or the public,

b) independence (autonomy) from external establishers in managerial decisionmaking and management,

c) at least a minimum proportion of total revenues comes from the sale of goods and services,

d) the ability to handle economic risks,

e) there are limitations on the disposal of assets (so called assets lock).

3. Environmental and Local Benefit

a) preferentially satisfying the needs of the local community and the local demand,

b) preferentially making use of local sources,

c) taking into account the environmental aspects of production and consumption,

d) cooperation of the social enterprise with local partakers (České sociální podnikání \{Czech Social Enterprise\}, 2015). 


\section{Distinguishing signs (Indicators)}

The Ministry of Labour and Social Affairs of the Czech Republic defined a list of distinguishing signs, or indicators, which were created in cooperation with the company P3 - People, Planet, Profit o.p.s. ${ }^{3}$ They make it easier to identify a social enterprise. Two sets of distinguishing signs were created - for a social enterprise (general) and for an integration social enterprise (WISE). These indicators fall into five areas: beneficent aim, social benefit, economic benefit, environmental benefit and local (or community) benefit. One or more indicators are specified for each of these areas, including a specification of how they are met by businesses. Both sets of these indicators are available and may be downloaded at this website: www.ceske-socialni-podnikani.cz. They make it easier for society to tell which company is a social enterprise and which is not.

\section{Sets of indicators (distinguishing signs) for a work integration social enterprise (WISE)}

Work integration social enterprise is a business where out of the total number of employees in the enterprise, $30-50 \%$ of employees are people who are disadvantaged on the labour market.

\section{Beneficent aim}

a) The business has an aim which benefits the community or the public and consists in the employing and social inclusion of persons who are at a disadvantage on the labour market; this aim is formulated in the articles of associa-

\footnotetext{
${ }^{3}$ Translator's note: o.p.s. - beneficent association
} 
tion or in similar documents on the establishing of the enterprise, and these documents are publicly accessible.

2. Social benefit

a) The proportion of employees from disadvantaged groups represents more than $30 \%$ of employees and this information is publicly accessible,

b) employees from disadvantaged groups are provided support which takes into consideration their specific needs,

c) the employees or members are regularly and systematically informed about the performance and economic results of the company, and about attainment of the socially beneficent goals, and at the same time, they participate in the decisions on the direction of the company,

d) employees from disadvantaged groups are provided education according to their individual possibilities.

3. Economic Benefit

a) More than $50 \%$ of the possible profit is reinvested into the development of the social enterprise or into the achieving of the declared beneficent aims, and the information specifying how profit is used is publicly accessible,

b) managerial control of the company is independent from its external establisher or owner,

c) the proportion of revenues acquired from the sale of goods and/or services forms at least $30 \%$ of the total revenues of the company.

4. Environmental Benefit

a) The company has formulated the principles of its environmentally friendly administration and operation and implements these principles in practice.

5. Local / Community Benefit

a) the company preferentially satisfies the needs of the local community and the local demand, 
b) the company preferentially uses local sources (i.e. it employs local people, buys from local suppliers),

c) the company communicates and cooperates with the local partakers. (Kurková, Francová and Bednáriková, 2015, pp 58-59)

\section{Proposed legislation in the Czech Republic}

At present, work on the legislation on social enterprise has been going on. The preview of legislative work for the period between 2015 and 2017, which was acknowledged by the Czech government meeting in March 2014 under no. 165, also includes the substance of the law on social enterprise. The sponsor of the bill is the Minister for Human Rights, Equal Opportunities and Legislation and its co-sponsors are the Minister of Labour and Social Affairs and the Minister of Industry and Trade. (Government of the Czech Republic, 2015). An act on social enterprise should define the term social enterprise so that it is evident who is a social entrepreneur and who is not. It is assumed that social enterprises will only be profit-making companies which are established under the Act on Corporations. The artificial persons under this act include the following types of businesses: unlimited liability company, limited partnership company, limited liability company, company limited by shares, cooperative and social cooperative. Social cooperative is a type of company that has been in effect since 2014 and that guarantees the status of a social enterprise. The passing of the bill should also lead to the creation of a register of social enterprises. On the other hand, for social entrepreneurs, the benefits for businesses introduced by the act will also be an important factor. The act should come into force in 2017.

The act will be interconnected with the new Public Procurement Act. By 2016, all EU member states must adapt their public procurement acts so that the con- 
tracting or awarding authorities can apply special conditions for the social and environmental area and emphasise the criterion of quality over the criterion of the lowest price more effectively. This will enable better access to public contracts for small and medium-sized entrepreneurs and especially for social enterprises (Melková, 2014).

\section{Support for social enterprise}

During the previous subsidy period, 122 projects under the OP $\mathrm{HRE}^{4}$ call for proposals no. 30 were supported and implemented in the amount of almost CZK 400 million, and 44 projects received investment support of almost CZK 140 million under the IOP $^{5}$ calls no. 1 and 8. (Ministry for Regional Development CZ and the European Social Fund in the Czech Republic, 2015). A new call for proposals no. 015 with the aim to support social enterprise was announced in August. This call is to support new as well as existing social enterprises which employ the long-term unemployed or people who were unemployed repeatedly, disabled people or people who were released from serving the sentence of imprisonment or another type of institutional sentence. A well-worked-out business plan is a precondition for obtaining the grants. (ESF in the Czech Republic, 2015) However, it is highly necessary to realise that establishing a social enterprise is a long process for which a healthy organisation, the right people and a great amount of energy are needed.

We can also include the Czechoslovak Commercial Bank as another supporter of social enterprises as for three consecutive years now, this bank has been supporting social enterprises either with funds, or by providing them with professional

\footnotetext{
${ }^{4}$ Translator's note: OP HRE: Operational Programme Human Resources and Employment

${ }^{5}$ Translator's note: IOP - Integrated Operational Programme
} 
advice and consulting in order to help them make their activities more effective. So far, 19 social enterprises have been supported with an amount exceeding CZK 1.5 million (Czechoslovak Commercial Bank (CSOB), 2015).

\section{Funds from Non-bank Institutions}

When starting a business, sufficient funds are the basic requirement. Without funds, it is not possible to incorporate a company under the Act on Corporations as the preconditions of the act include a record on establishing the company by a notary public, incorporation into the Register of Companies and arranging for a Business Licence, and all of these steps need to be paid for. We cannot overlook other costs linked to entrepreneurial activities, such as wages, fuel, material, services, advertising, and the like. If an individual is really motivated but wants to start a business without own funds and guarantees, a bank will probably not be willing to assist. One of the problems for small businesses is the absence of microfinancing. Would-be entrepreneurs are often unable to obtain loans or credit from banking institutions because they have no surety and banks do not see them as partners for business.

\section{“Chance for Development" Project}

The project "Chance for Development" started on the basis of an initiative of the European Social Fund to support microfinancing, and as the first such project in the Czech Republic, it makes it possible for microenterprises and sole traders to access funding. The purpose of microloans is to support small and social enterprises, to create sustainable employment opportunities and thus to solve the problems of socially excluded groups of the population. This especially includes the 
long-term unemployed or people with disabilities who thus have a better change of finding suitable jobs. Support primarily focuses on small entrepreneurs starting a business for whom obtaining a loan from banking institutions is beyond their possibilities. The project is implemented by the company OCCASIO o.p.s. that has been supporting the social area on a long-term basis, in cooperation with Bankovní institut vysoká škola a.s. Microloans are intended to help the entrepreneurial entities which get the loans so that they can prosper in the future. They are repayable loans for businesses in an amount of up to CZK 500 thousand, so they are not a donation. Microfinancing has emerged from needs and weak points. The conditions for microcredit are similar to those offered in banking institutions but surety and maturity are evaluated based on individual possibilities and under ethical conditions. Unlike in banks where standard charts are used for all, evaluation of applications for microloans is always done on a case by case basis. (Occasio, 2015) One of the social enterprises which relied on non-banking financing is the company z5smysl from České Budějovice. The company runs a shop and a clothes rental L'Skř́iň Boutique. People can rent clothes for business meetings or appointments which they otherwise couldn't afford to buy. The rental buys clothes from young, starting Czech designers and supports them in this way. (Ministry of Labour and Social Affairs ("MoLSA", 2015)

In the periods to come, there will be more possibilities for the support of small and medium-sized businesses. The Ministry of Industry and Trade ("MIT") has been preparing the establishing of a new fund that should bring financial support for start ups. The National Innovation Fund should become a new source of support. This fund wants to draw on foreign experience with the funding of innovative firms through venture capital. Start-ups are a motivation to start a business for graduates and students who may have good ideas but cannot implement them without support. Start-ups have a quick start and a potential to create profit and 
new jobs, without the risk of lifetime indebtedness. The fund will support selected projects in the form of equity participation but it will never be the only investor. In this way, starting entrepreneurs cannot rely solely on external sources (MIT, 2015).

\section{Social enterprise statistics}

Since 2013, the number of social enterprises has grown by $100 \%$. The first investigation was carried out by P3 - People, Planet, Profit o.p.s. in cooperation with the ProVida Foundation within the TESSEA project in order to verify the situation of social enterprises in the Czech Republic. 143 companies in total were asked for cooperation but the investigators managed to investigate in only 100 of them during the period between October 2012 and January 2013. The acquired data were evaluated in February 2013. The next survey was conducted after a year, from October 2013 until January 2014 and this time again, 143 social enterprises registered in the directory of social enterprises were invited to participate, out of which 115 companies participated in the survey. The last data acquired through the directory mapped the situation as at October 2015. (České sociální podnikání \{Czech Social Enterprise\}, 2015). It is possible to discern from the obtained data that is some regions, social enterprise has been gaining momentum while in others, for instance in the Karlovy Vary Region, this new type of business is not doing that well.

Social businesses most frequently offer services in the area of gastronomy (33\%), or engage in food production and sale (17\%), hospitality and accommodation (16\%) and the same proportion deals in sales. A fifth of social enterprises provides gardening and cleaning services or maintenance of real estate. $99 \%$ of these companies employ people with some kind of disadvantage. Two thirds 
employ disabled people, one third employs the long-term unemployed and 13\% employ members of ethnic minorities. The most prevalent legal form is a limited liability company (45\%), and the remaining forms are beneficent companies $(28 \%)$, associations $(10 \%)$, sole traders $(8 \%)$, cooperatives $(6 \%)$ and religious societies (2\%). The rest are companies limited by shares, common-purpose associations and subsidiary associations. Since 2013, the limited liability company has undoubtedly become the dominant legal form and there is a clear prevalence of for-profit, business organisations over non-profit legal forms (České sociální podnikání \{Czech Social Enterprise\}, 2015).

\section{Examples of good practice}

The social cooperative Stabilita Olomouc was founded in 2012 as an enterprise of the non-profit organisation P-centrum which has been providing social services to people with addictions since 1993. The cooperative tries to help clients of social services and offers them jobs on the open labour market. First, the clients go through the induction training in the safe environment of the Café and with the support of a professional team, and then the cooperative makes it possible for them to work in employment. Within the framework of call 30 in support of social enterprise, the cooperative created four jobs in the Café where the clients acquire proper work habits, practice and experience with legal work. The social cooperative operates according to the principles for social enterprises. Its employees participate in the management of the company and are provided further professional education. Profit is reinvested into the enterprise or is used to achieve the beneficent aim and at least $40 \%$ of the employees are from among people who are disadvantaged on the labour market. An important feature of this social enterprise is the interconnection of social work and social enterprise, in- 
cluding the focus on individual needs of a disadvantaged person. The social cooperative Stabilita is a good example of a company which received support at the beginning and even after provision of support to the company ended, the cooperative continues to operate and is developing further (Stabilita, 2015). 


\section{References}

Bednáriková, D. \& Francová, P. (2011): Studie infrastruktury sociální ekonomiky v ČR: plná verze. \{Study of social economy infrastructure in the Czech Republic: Full Version\} Praha: Nová ekonomika \{New Economy\}: p. 63. ISBN 978-80-260-0934-4.

České Sociální Podnikání \{Czech Social Enterprise\}, 2015. [online] 2015 [cit. 2015-11-12] Available from: http://www.ceske-socialni-podnikani.cz/cz/

Czech Republic. Act no. 108/2006 Sb., On Social Services. 2006. In: Collection of Laws of the Czech Republic. 6. 1. 2012, Part 37. 2006 ISSN 1211-1244 [online]. [cit. 2015-05-30]. Available from: http://www.zakonyprolidi.cz/cs/2006-108

Czech Republic. Act no. 90/2012 Sb., On Corporations and Cooperatives (The Act on Cooperatives). Part 34. 2012 [online]. [cit. 2015-09-30]. Available from: http://www.zakonyprolidi.cz/cs/2012-90

Csob Grant Program for the Stabilisation of Social Enterprise, [online] 2015 [cit. 2015-011-12]. Available from: https://www.csob.cz/portal/o-csob/spolecenska odpovednost/granty/csob-grantovy-program-stabilizace-socialnich-podniku

European Social Fund in the Czech Republic, 2014. Support of social enterprise in the Czech Republic. [online] 6 February 2013 [cit. 2015-05-12] Available from: http://www.esfcr.cz/projekty/podpora-socialniho-podnikani-v-cr

Kurková, G., Francová, P. \& Bednáriková, D. (2015): Manuál: jak založit sociálni podnik. \{A handbook: How to establish a social enterprise. $2^{\text {nd }}$ edition. Praha: P3 - People, Planet, Profit, p. 61, ISBN 978-80-260-7401-4. 
Melková, G. (2014): Společensky odpovědné zadávání zakázek. \{Socially Responsible Procurement $\}$. Office of the government of the Czech Republic, Dept. of Social Inclusion: ISBN 978-80-7440-087-2.

Ministry of Labour and Social Affairs of the Czech Republic. V Česku chybi sociálni podnikatelé, zájem investorů pritom roste \{A lack of social entrepreneurs in the Czech Republic despite growing investors' interest\} (HN). Hospodářské noviny \{Economic Daily\}: 2015. [online] 6 November 2015 [cit. 2015-05-12] Available from: http://www.mpsv.cz/cs/22770

Ministry for Regional Development of the Czech Republic. Government of the Czech Republic 2015. Integrated Operational Programme. [online]. [cit. 201505-12] Available from: www.strukturalni-fondy.cz/iop,

Ministry of Industry and Trade. 2015. Vláda dnes dala zelenou návrhu MPO na vznik fondu na podporu startupi. \{The government okayed the Ministry of Industry and Trade proposal for the establishing of a fund to support start ups\} [online] 12. 10. 2015 [cit. 2015-10-13] Available from: http://www.mpo.cz/dokument165184.html

Mikrofinance. \{MICROFINANCE\} 2015. [online] 2015 [cit. 2015-11-12] Available from: http://www.occasioops.cz/Socialni\%20mikrofinance.html

Government of the Czech Republic. 2015. Plan of legislative work of the government for the year [online] 7 January 2013 [cit. 2015-11-12] Available from: http://www.vlada.cz/cz/media-centrum/dulezite-dokumenty/plan-legislativnichpraci-na-rok-2015-125665/

Stabilita 2015. [online] [cit. 2015-11-12] Available from: http://www.stabilita$\underline{\text { olomouc.cz/ }}$ 


\title{
Social Economy in Poland - Overview of the Development and Current Situation of Social Economy Entities
}

\author{
Witold Mandrysz
}

\section{Introduction}

In Poland the importance of the idea of Social Economy has been growing recently. It is followed by the development of social economy institutions and other manifestations of social entrepreneurship. On one hand this is a reaction of requirements arising from the problems of marginalization and social exclusion and on the other hand it is an attempt to search for new solutions in social policy. The EQUAL Community Initiative was part of the EU's strategy for creating better workplaces and providing broad access to them. EQUAL was a way to search for new mechanisms for solving the problems of discrimination and inequality in the labor market through international cooperation. This initiative has also become an essential tool for the promotion and dissemination of knowledge on the concept of Social Economy (the new Social Economy) in Poland. One of the main activities of social economy is combating social exclusion and marginalization in the labor market.

The purpose of this text is a brief attempt to present basic information on how social economy is understood and implemented in Poland, to introduce the practical forms of its functioning and the basic regulations in this area and to highlight the socio-political context in which the sector operates. This text is partly based on empirical material. This chapter presents the experience and draws conclusions from interviews the author conducted with experts and individuals who were not directly involved in the various forms or products of 
the operation of social economy institutions but were supporting or promoting them in the region. These interviews are included in the study "Social economy in the Silesian Voivodship" prepared for the Institute for Public Issues by a team led by Professor Kazimiera Wódz. ${ }^{1}$

They included among others representatives of several non-government umbrella organisations, foundations or representatives of the European Social Fund Department of the Marshal Office of the Silesian Voivodship, the institution which is responsible for implementing operational programmes on regional level, under which actions in the scope of social economy may be funded.

In the interviews the respondents were asked, among others, to define what they thought social economy was and how it manifested itself, to assess the way social economy initiatives functioned in the region. In addition they were asked to give opinions on the cooperation and the support local public authorities provided to the various forms of social economy in the region. They were expected to assess the preparation of NGOs to take actions in this respect, to assess legal regulations created on central, regional and local level regarding the functioning of social cooperatives etc. We wanted to know their opinions on regional and local development strategies and strategies for solving social problems as well as possibilities of the functioning of social economy entities based on these strategies. We also wanted to know what they thought about the further perspectives or possibilities and dangers of the development of social economy in the region.

1 Ekonomia społeczna w województwie śląskim. Wybrane przykłady. Ekspertyza przygotowana dla Instytutu Spraw Publicznych w ramach projektu IW EQUAL „W poszukiwaniu polskiego modelu gospodarki społecznej. Budujemy nowy Lisków" Team: K. Wódz (scientific leader), K. Faliszek, W. Mandrysz, A. Niesporek, B. Kowalczyk, M. Szpoczek; 
This research was partly repeated by the author of this text in 2015 with the representatives of the NGO sector and Social Economy entities.

\section{Basic definitions of social economy idea and social economy entities}

Talking about social economy we face the lack of unambiguous understanding of this term as well as some related terms, such as community economy, community capitalism etc. Social economy oscillates between the idea of socially engaged capitalist economy on the one hand, and an alternative to the capitalist form of community, non-market economic activity on the other hand.

P. Sałustowicz suggests the possibility of interpreting social economy from several perspectives:

a. From the perspective of employment policy and the labour market - social economy is seen as a "jobmachine"; it is expected to create new job places, particularly for the marginalized people or those who are endangered by social marginalization; it should provide services involving job training and other forms of support preparing the unemployed for the transfer to the 'primary' labour market.

b. From the perspective of social policy - social economy can serve as compensation in the situation of failure of market mechanisms and the failure of the welfare state, by providing social services for individuals and collectives or local communities, particularly where the public and private sectors are not able to meet the growing social needs.

c. From the perspective of social integration - the task of social economy is to accumulate social capital as a network of social relationships. In the framework of a group or community there are the available resources 
which are available only to their members exclusively on the basis of the network of their mutual connections. The more extensive the connections the greater the chance to access/activate resources which are not individually owned.

d. From the perspective of the democratisation process - social economy is expected to draw individuals and social groups into the political decision-making process. This assumption is connected with democratic and participatory way of management of social enterprise. Through such an experience individuals are expected to become more active as citizens and more involved in social and political life.

e. From the perspective of social change - social economy should be a place for creation of an alternative economic and social system. ${ }^{2}$

But this perspective is not shared without doubts. J. Hausner more or less agrees with the first three functions, but he is sceptical about the last two ones. However, he states: "The social economy clearly will not eliminate traditional social welfare and is not a solution that will bring about professional activation for all persons from disfavoured groups. However, the task of social economy entities is not to exclusively activate and integrate such people through employment. They assist the disadvantaged in many ways by providing them various types of services, including caretaker services, each time involving them in a kind of community. In this sense as well, the following issue is always worth considering: the one that is offered by social welfare could simply be provided more effectively by a social economy entity, particularly if it is also capable of earning its own funds. Looking at it in this way, social welfare in the broad sense be-

2 P. Sałustowicz, Koncepcje i funkcje ekonomii społecznej, in P. Sałustowicz, H. Guzowska (ed.), 'Ekonomia społeczna a bezradność społeczna-perspektywy i bariery' (BRPO), Warsaw 2006, p. $13-35$. 
comes a perspective of public authority which, fulfilling its assistance function and guided by the principle of helpfulness, will perceive the social economy as a way to achieve social goals and solve problems."3

In the present wide-ranging considerations a so-called old and new social economy can be distinguished. The term old social economy is used to define activities related to various forms of co-operatives, mutual insurance societies, etc., whose tradition dates back to the nineteenth century. It is estimated that in the Second Republic of Poland, every fifth adult citizen was a member of a cooperative. In economic terms, in 1938 in the retail trade, the share of the cooperatives was 4-5\% of the total turnover: in the procurement of agricultural products - according to various calculations - from $1.5 \%$ to $12 \%$. Roughly one-fifth of savings deposits was placed in cooperative banks and Kasa Stefczyka (cooperative savings and loan $)^{4}$. In the socialist era, the activity that fitted well with the idea of the social economy, as a movement of cooperation outside the institution of authority and its control, was undesirable and was regarded as a potential threat to the socialist social and political order, and therefore had to disappear.

The new social economy can be defined as those types of social enterprises whose objective is the growth of social cohesion within local communities. ${ }^{5}$ The primary goal is the effective linking of social elements in the community to economic units. Many different institutions with different legal bases such as social enterprises, social cooperatives and social integration centres, etc., that have a mission to prevent social exclusion, to develop professional activation of

\footnotetext{
${ }^{3}$ A. Giza-Poleszczuk J. Hausner J. [ed.] The Social Economy in Poland: Achievements, Barriers to Growth, and Potential in Light of Research Results, Warszawa 2008, p. 16

4 A. Piechowski „Rodowód przedsiębiorczości społecznej” w Przedsiębiorstwo społeczne w rozwoju lokalnym [red] E. Leś, M. Ołdak Collegium Civitas Warszawa 2007:45

${ }^{5}$ cf. T. Kaźmierczak, Zrozumieć ekonomię społeczna, in: T. Kaźmierczak, M. Rymsza (ed.), Kapitał społeczny. Ekonomia społeczna, Instytut Spraw Publicznych, Warszawa 2007, p. 93-126;
} 
marginalized people socio-economically and to increase organization of the Third Sector ${ }^{6}$ are parts of the New Social Economy.

Current attempts to define social economy are associated with the Charter of Principles of Social Economy CEP-CMAF from 2002 $2^{7}$ social economy organizations (social and economic entities) operate in all sectors. They are distinguished mainly by their objectives and the characteristic form of entrepreneurship. Social economy includes organizations such as cooperatives, mutual societies, associations and foundations. These companies are particularly active in certain areas like social protection, social services, health care, banking, insurance, agricultural production, consumer issues, associative work, crafts, housing, supplies, neighbourhood services, education and training, and in the area of sport, culture and recreation.

In the context of the fight against social exclusion, social economy is understood as initiatives in the field of labour market policy, in particular the socioprofessional integration of socially excluded groups, opposing the unjustified polarization of income societies. ${ }^{8}$ Polish institutions treated as social economy entities are: Centres of Social Integration, Social Integration Clubs within the social employment and Social Cooperatives and Vocational Rehabilitation Facilities. The civil sector entities should be added to the above-mentioned institutions.

\footnotetext{
${ }^{6}$ Compare: M. Rymsza Druga fala ekonomii społecznej w Polsce a koncepcja aktywnej polityki społecznej. [w]: T. Kaźmierczak, M. Rymsza (red.), Kapitał społeczny. Ekonomia społeczna, Instytut Spraw Publicznych, Warszawa 2007, p. 175-176;

${ }^{7}$ Cooperatives, mutual societies, associations and foundations (CMAF ) deemed it essential to establish a permanent dialogue on European policies that are of common interest. In November 2000, they set up the European Standing Conference of Cooperatives, Mutual societies, Associations and Foundations (CEP -CMAF). In January 2008, the $\mathrm{CEP}-\mathrm{CMAF}$ changed its name into Social Economy Europe http://www.socialeconomy.eu.org

${ }^{8}$ E. Leś „Nowa ekonomia społeczna wybrane koncepcje” Trzeci Sektor 2 Fundacja Instytut Spraw Publicznych Warszawa 2005: 37
} 
Analysing the development of this sector in recent years and its contribution to the employment, the following data show a fairly dynamic growth - at the end of 2010 almost 124.000 persons were employed by the Third Sector organizations, and for 103.000 people it was their main place of work. Comparing it with the data from 2008 it can be seen that nearly 71.000 people were employed and for more than 60.000 it was their main place of work. Among the respondents from the end of 2010 the number of non-governmental organizations with registered business was 7.24 according to CSO (foundations, associations, social organizations, churches and religious associations, etc.), while the research shows that only half of them conducted actual economic activity.

In the cooperative sector (traditional cooperatives, cooperatives of the disabled and blind, folk handicraft cooperatives, etc.) the main merit is the high percentage of employment of people with disabilities (three times more people with disabilities are employed here than in the whole system of the national economy). In the cooperative sector, according to the REGON system, 17.000 companies are registered, however, only 9 thousand ones are active economic entities. According to the same system in the years 2007-2012 the number of registered cooperatives decreased from 18.200 to 17.153 .

Social cooperatives are a new type of cooperative and are often founded by people at risk of social exclusion. These types of cooperatives are usually established by the unemployed ( $82 \%$ of the established cooperatives) and disabled people $(38 \%$ of cooperatives have at least one disabled person among the founders). These cooperatives are guaranteed with statutory forms of support. When these cooperatives are established, financial support and the ability to refund part of social security contributions seem to be highly important. According to the National Court Register at the end of 2012 six hundred and one social cooperatives were registered, however, the number of the actually actively operating 
entities is not known. Broadly defined services (maintenance and upkeep of green areas, laundry services, service of household appliances / electronics, construction, catering) are included in their main field of activity. In 2010 half of the subjects had a negative balance of cooperative activity, $27 \%$ managed to balance their income and expenses and only $23 \%$ had a year-end surplus. At the same time it should be noted that the main source of revenue for the cooperative (almost $75 \%$ ) would derive from the operational income in the open market. ${ }^{9}$

According to the data of the Ministry of Labour and Social Policy, in 2011 seventy-four Social Integration Centres operated (54 were formed on the initiative of the organizations of the Third Sector). Social Integration Centres have been introduced in the Act on Social Employment as a proposal for the unemployed, "who are subject to social exclusion and because of their life situation cannot satisfy their basic needs on their own and are in a situation causing poverty and preventing or limiting participation in professional, social and family life." 10 This form of support was used by 84.10 people in 2011 .

Social Integration Clubs are not engaged in economic activity, they do not produce goods or services but provide employment through the organization of socially useful work and public work. These two types of work are carried out to improve the environment, its aesthetic appearance, to adapt public buildings to the needs of disabled people, to improve the state of local roads, to develop services for residents, etc. The number of operating Clubs was 286 in 2010.

Vocational Rehabilitation Facilities act in relation to persons with disabilities. "...they are created for the employment of people with disabilities included in a significant degree of disability, as well as through vocational and social rehabilitation, to prepare them for life in an open environment and to assist in the im-

\footnotetext{
${ }^{9}$ See: Monitoring spółdzielni socjalnych A. Izdebski, M. Ołdak. MPiPS, Warszawa 2011.

${ }^{10}$ Ustawa o zatrudnieniu socjalnym 2003 Dz.U.03.122.1143:art1ust.2
} 
plementation of a full, independent, and active life for as far as their individual capabilities allow". ${ }^{11}$ In 2011 the number of Vocational Rehabilitation Facilities was 69 and they employed more than 3.5 thousand people of which 2.651 were persons with disabilities. ${ }^{12}$

To create a certain "ideal model" of social enterprise (by EMES), enterprises should meet economic and social criteria.

Economic criteria:

- conducting permanent activity with a direct aim for producing goods and services;

- high level of autonomy - social enterprise emerges as a voluntary initiative of a group of people who manage it, who decide whether it should continue or terminate its operation, although in terms of finance it may depend on public subsidies to some extent;

- considerate level of economic risk - the functioning of social enterprise depends on the efforts of its members, its staff and their ability to acquire the necessary resources;

- ability to use both paid and social labour in its activity.

Social criteria:

- the operation of social enterprise must be focused on supporting and developing the local community and promoting the sense of social responsibility on a local level. The production of goods and services should find the market niche;

- social enterprise comes into being as a result of the collective activity of people belonging to a given community, sharing the same problems or goals;

${ }^{11}$ Rozporządzenie w sprawie Zakładów Aktywności Zawodowej $2000 \mathrm{z}$ dnia 31.01 Dz.U.nr6,77: art.2.1

${ }^{12}$ Biuro Osób Niepełnosprawnych MPiPS. 31.12.2012 roku. 
- the democratic management of social enterprise is not subordinated to owning capital shares;

- social enterprise may be organisations which cannot redistribute their profits and entities like cooperatives which may distribute their profits only to a limited extent. ${ }^{13}$

Social economy is an important factor of local development - it creates jobs, extends the range of services, allows to fulfil human needs in a better way. It may also create a complex system of local economy relations (community economy), it can include non-government organisations in the areas belonging to the activity of the local government and can affect the creation of the local and neighbourly forms of economic cooperation and mutual support. The aim of the previously defined social economy is to create inclusive local labour market, especially dedicated to people who are particularly endangered with social marginalisation ${ }^{14}$. For some of them it is the only form of employment, and for others - a form of transitory economic activity on their way to the open labour market.

The respondents who were to define the meaning of social economy often could not express their opinion in an unambiguous way. It corresponds with the general tendency of having no precise definition of what social economy is, what kind of institutions can be considered to be the subjects of social economy and whether non-government organisations may also be included or not etc. In their arguments, some respondents drew attention to the social dimension of this issue, which has an important or even prevailing advantage over the economic

${ }^{13}$ Cf. M. Sztrak, M. Sliwiński: Jak założyć przedsiębiorstwo społecznie zakorzenione? Warszawa 2008; T. Kaźmierczak, Zrozumieć ekonomię społeczna, in: T. Kaźmierczak, M. Rymsza (ed.), Kapitał społeczny. Ekonomia społeczna, Instytut Spraw Publicznych, Warszawa 2007, p. 110;

${ }^{14}$ A. Zybała ${ }_{2}$ Rynek pracy społecznie integrujacy, zadania dla lokalnych partnerów, „Dialog” no. 2; 
component. According to the respondents, actions taken in this respect are bound to improve the functioning of the marginalised groups or those who are endangered with marginalisation, based on their resources and the resources of the local environment they live in. Representatives of umbrella organisations argue that "social economy is a specific kind of economic activity, in which it is not the profit that motivates for action but the very support for the marginalised groups on the labour market". According to them "it is one step further than social responsibility of business, where economic and social factors are equal and the social factor is more important" (SWR), but they also stress that it cannot happen in isolation from the economic reality, which sometimes seems to be forgotten by those who make decisions within the framework of social economy." Every action taken within the framework of social economy should have reasonable economic possibilities of functioning, and their effects must be - in their opinion - more attractive for the immediate beneficiaries of such actions so that they would like to be involved in them.

There were also opinions that the social component of this activity cannot be the justification for economic inefficiency of actions taken in this respect. Representatives of regional administration call the attention of the situation of social economy initiatives. They underline that they cannot be bound to only the state or the economy, which means it serves as a space for NGOs and they emphasised that in the new financial conditions resulting from the implementation of Regional Operational Programmes on one hand and the Operational Programme Human Capita ${ }^{15}$ on the other hand, actions in the scope of the broadly conceived social economy will be much easier than they have been so far, and the range of initiatives will be wider.

\footnotetext{
${ }^{15}$ These are some of the programs on the basis of which the European Social Fund was planned and issued.
} 
Eight years after conducting the comparative research, responses still indicate the lack of a precise definition of social economy. Even with no precise definition, experts typically utilize two existing overarching views: (1) the EMS approach developed earlier and (2) a slightly broader one developed by the National Program for the Development of Social Economy. This is a government document that shows the key directions for public engagement to create the best possible conditions for the development of social economy and social enterprises. Its definition of social economy includes not only social economy entities but also institutions and organizations that support them. It is important to note that these definitions of social economy are not mutually exclusive but complementary ones. Thus, the definition of social economy is defined more precisely using the idea of the EMES with all it connotations.

Referring to the functioning initiatives of social economy in the region, the respondents point out a kind of stagnation and weakness in comparison with the euphoric interest in this subject and the initiatives taken in early 2006 when this form of activity was treated as a specific remedy for the problem of social exclusion. Later experiences connected with the introduction of legislative regulations in this respect as well as some problems resulting from practical attempts at pursuing this idea, with the lack of external support and favour on the part of local authorities led to a slow deterioration of some social cooperatives or to the resignation from finalisation of the previously planned initiatives.

Today there is a revival of interest in this type of activity. This interest is different and broader because it does not arise only comes from entities that want to act within the sphere of social economy or those who are willing to support such 
activity. The organizational weakness of most functioning social cooperatives may be a result of legal regulations which state that $80 \%$ of the members of cooperatives should be people who are socially or professionally excluded or endangered with such exclusion. There is an assumption in this regulation that individuals who have not been able to solve their problems independently in the existing economic and social conditions would be able to solve them in a cooperative. However, the functioning of cooperatives requires numerous competences and characteristics of entrepreneurs and those who are in the cooperatives are likely to be some of the people who lack them or lost them when they were out of work. Cooperative initiatives are strong as long as they are developed, led and supported by a leader - a social activist who, while not marginalized, excluded or endangered, will support and coordinate the actions of individuals in the cooperative who are marginalised, excluded or endangered. Should the leader leave the cooperative there is often a slow collapse of the whole initiative.

Another frequent cause of breakdown of social cooperatives - was - according to the respondents - the inability of such entities to function after they stopped being subsidised from the public resources at local, national level or within the framework of EQUAL Community Initiative. "It often happened that these entities stopped functioning when they lost the subsidies from the Poviat ${ }^{16}$ Labour Office, that is to say there was money for starting the initiative but there was none for its further functioning" (a representative of the ESF Department of the Silesian Marshal Office).

From an 8-year perspective there are two types of "pro-integration" social economy entities in Poland, those not directly focused on economic activity (Vocational Rehabilitation Facility, Occupational Therapy Workshops and some So-

\footnotetext{
${ }^{16}$ Powiat is the second-level unit of local government and administration in Poland.
} 
cial Integration Centers, and those more directly focused on some kind of economic activity. Recently the first ones have been doing quite well while the latter ones, even though they are still developing, are in a weaker condition.

\section{Social economy in Polish law and regulations}

Some of the most important legal acts regulating the functioning of the social economy are those that involve cooperatives, employment, employment of people with disabilities and whether for public benefit etc:

Co-operatives:

- Cooperative Law, 1982

- The Act of social cooperatives, 2006.

- Regulation of Minister of Labour and Social Policy on allocating funds to undertake activities under the terms of the social cooperatives,

- Regulation of Minister of Labour and Social Policy on the social cooperative model application for a refund of premiums paid and the method of making their return, 2009.

- Regulation of Minister of Labour and Social Policy on determining the model certificates attached to the application for entry of a social cooperative in the National Court Register 2007

Employment:

- The Act of social employment, 2003,

- The law on employment promotion and labour market institutions, 2004.

Employment of people with disabilities and mentally ill people:

- $\quad$ The Act of Mental Health, 1994. 
- The Act of Vocational Rehabilitation and Employment of Persons with Disabilities, 1997.

- Regulation of Minister of Labour and Social Policy on professional activity establishments, 2012

Charitable activities:

- The Act of Public benefit activity and volunteerism 2003.

In 2007 the majority of respondents stated that the restrictions imposed by central and local legislation restrict the development of cooperatives in Poland. Furthermore, they felt that the laws needed to be adjusted to reflect the changing reality. The experience of Western European countries does not fully mesh with the cultural and economic reality of Poland. Experts stressed that there was not only a lack of legal regulations but the systematic action procedures often had discouraging effect from taking actions in the scope of social economy. It is the registration procedures of social cooperatives that cause the most problems for the beneficiaries of social economy. The opinion of the experts is that "the basic problem is the registration of social cooperatives - this is a terrible ordeal when an unemployed person meets with obstacles on the part of officials" (The Helping Hand Foundation - NGO), and when "somebody lacking clout and patience is unlikely to get things done" (The Fenix Partnership for Development - NGO umbrella organisation). In their social economy instruments, Italian or French partners focus on spreading the idea of social economy through the simplification of the procedures, therefore we should follow their example and simplify the procedures. Then more beneficiaries are likely to endeavour to set up social cooperatives. In that period regulations of social cooperatives were very strict and difficult to cope with. E.g.: there was an obligation that at least $80 \%$ of the members of social cooperative had to be from socially excluded groups. It cre- 
ated severe difficulties and problems not only with running the entities but also with the successful implementation. Fortunately the legislation was changed last year. Currently the members of the cooperative can also be people from other than the members of the socially excluded groups and where the law involves specialists, their number cannot be bigger than $50 \%$ of all the members of the cooperative. The initiative is that social cooperative can be created by local

government organizations, NGOs or religious agencies. In these cases the organizations try to limit their influence on the cooperative and try to move them toward independent functioning. When these organizations initiate a social cooperative they are required to employ at least five (5) members from groups of people that are excluded, marginalized or at risk of social exclusion in that cooperative. Most experts agree that this change in the law was the primary factor in the development of social cooperatives in the last few years. It is evident that record growth can be experienced in social cooperatives where legal services are provided to persons.

\section{Social economy in socio-political practice}

In recent years the idea of Social Economy has become increasingly known not only in the world of literature and theoretical considerations but also in daily practice. Social entrepreneurship has been accepted as an innovative and practical solution to the problem of unemployment, not only on the level of regulations and official policy discourse but also in every day actions of more and more local municipalities and other socio-political actors.

"The social economy is not only the result of legal resolutions and acts. It is not only a question of social awareness, though public support is very significant. The social economy is a social movement that should lead to a new vision for 
Poland's development. The social economy is a way of involving the third sector in Poland's economic development" - Jerzy Hausner, former Minister of Labor and Social Policy and former Vice-Premier. ${ }^{17}$

The respondents of both the third sector and regional government institutions, who took part in interviews in 2007, emphasised how important non-government organisations were for the development of social economy. They drew attention to the potential they have: their willingness to engage, their knowledge on different types of social problems and their experience in working with socially excluded individuals.

All this results in treating non-government organisations as a natural partner and entity supporting actions taken among others by social cooperatives. They argued that the effective activity of non-government organisations for the social economy entities is limited by problems with premises, lack of funds, insufficient staff with professional preparation. The resources are necessary when initiating actions in the field of social economy and when providing support in the form of consultations, legal advice or advice on business and accounting.

The respondents attributed the important role in the development of the social economy to organizations that promoted and popularized the idea of using the patterns of Western countries within the framework of IW EQUAL in Poland. The respondents pointed out many positive practices, experiments and mechanisms, which have been developed as part of such projects. The representatives of the umbrella organizations considered the presence of an effectively functioning leader necessary to success within the framework of social economy and supporting excluded persons. The leader needs to be supported by the local government representative who is aware of the importance of this problem. The goal of the

\footnotetext{
${ }^{17} \mathrm{http}: / /$ www.ekonomiaspoleczna.pl///433523, 15.09.2015;
} 
leader is to mobilise the resources of the local community, non-governmental organizations and the excluded persons to improve actions taken by the whole community to improve the functioning of individuals at risk of exclusion. As respondents said "Only if there is local government, preferably a president or mayor who is aware of the possibilities of NGOs, and if there is a strong leader who represents these organizations there is going to be a success - a leader who can trigger the potential and possibilities". (SWR - NGO umbrella organization).

Most of the respondents participating in the research conducted at the early stage of development of Social Economy singled out (1) the lack of competence and conceptualization on how to develop the social economy and (2) the reluctance of the majority of local governments or public institutions to cooperate and be partners in these entities which they are required by law to do. As one of the respondents said: "local government is ignorant of social economy and that's why there is little support for such initiatives" (The Feniks Partnership for Development). Some positive examples of towns or Poviat Labor Offices that actively support these activities were pointed out but the majority of local selfgovernment authorities restrict themselves to only subsidizing such initiatives for the legally required length of time. "The gmina authorities provide money for starting an activity and that is all, there is no continuing protection umbrella" (a representative of the ESF Department of the Silesian Marshal Office). There is no vision how to support the function of these entities or cooperatives once they start activity and to help them to get orders.

Also, the efforts of umbrella organisations towards changing the way of thinking of the representatives of public administration on different levels in the scope of popularisation of the idea of social economy is very difficult and is often ineffective. "It is very difficult to work on changing the way of thinking of such 
institutions. The way non-government organisations work and the way these institutions function are radically different" (SWR). Public administration's excessive bureaucratic and formalized way of acting deters non-governmental organizations interested in cooperation. Too often rigidly following public procurement laws, ordered tasks, etc., is simply a pretext for not granting support. "Gminas are not at all willing to distribute orders to perform public tasks among subjects of social economy" (a representative of the ESF Department of the Silesian Marshall Office). The view of respondents was that knowledge by representatives of public administration at different levels concerning the social economy, social cooperatives etc. is radically low. Units of public administration are not able to see it being used as a method of solving problems of social marginalization in particular gminas or poviats. Knowledge about instruments of the social economy is particularly evident in small gminas where there is a lack of qualified specialists and a strong leader responsible for promoting the idea of a civil state. Beneficiaries of the social economy typically meet resistance from officials that see grassroots initiatives as challenges with extra tasks to perform. In the 2007 interviews, particular attention was focused on the problems arising from the restrictions posed by local legislation in terms of social economy.

Social economy is primarily dedicated to local communities, but local authorities fail to take an active part in implementing this idea. Even if the strategic documents of particular gminas ${ }^{18}$ include provisions on the promotion of the idea of social economy, such provisions exist only in theory. Strategies of local and regional development should be documents which determine the line and spirit of political decisions in the context of social and economic development on a local and regional level and they often remain void and ineffective provision that

${ }^{18}$ Gmina - local government unit 
was made only for the sake of duty and with no actual application. Selfgovernment authorities often seem to restrict themselves to introduce provisions concerning social economy in local strategy and programs and assume that it will automatically activate the local community. However, it cannot be assured that including some provisions concerning particular tasks in those strategies or programs that they will be performed successfully.

Documents should favour legitimisation, facilitate and guarantee the continuity of the realisation and funding of grassroots activities.

After 8 years the opinion of experts about local government and its willingness for cooperation with the NGO sector and social economy entities seems to be much better. Most of local authorities (especially in bigger cities) seems to understand the importance of the NGO sector for local development and social economy for solving social problems. The role of the NGO sector is not only to support Social Economy entities. It is noted that now the strongest social economy entities are NGOs which conduct economic activity for solving social problems etc. The importance of these entities has been growing rapidly during the last years. Public opinion views social cooperatives as the most important social economy entities.

In the opinion of the respondents this situation is a heritage of EQUAL CI. Actions taking on the base of EQUAL which was a tool for implementation of Social Economy in Poland mostly concentrated on the promotion of Social Cooperative activity.

It is emphasised that also on the regional and national level trials of creation of better political and legal environment for developing of Social Economy can be observed. Speaking about examples respondents mentioned the estab- 
lishment of the National Programme for the Development of Social Economy. On 12th August 2014 the National Programme for the Development of Social Economy was adopted by the Polish Government. This government document shows the key directions for the development of social economy and social enterprises. It is addressed primarily to the public institutions responsible for creating and implementing policies but also to the people involved in the social economy sector. Their activities will be supported from the EU funds and the national budget.

As the respondents stressed, social economy gives huge possibilities and emphasises the self-development of the individuals to cope with new reality, it is also an opportunity for the integration of the local community. Social economy initiatives are focused on cooperation and unity of communities. It seems to be one of the significant functions of social economy. In regional development it is an opportunity, which is to be aptly used. "The perspectives are enormous $[\ldots]$ the very fact that it appeared on such a wide scale. Nongovernment organisations won't have to use informal ways in search of aid. They just get it. So, there are funds and instruments, you should simply use them (a representative of the Marshal Office of Silesian Voivodship). We need to learn social enterprise”. To sum up, the respondents agreed that ,it is going to be fine, as long as people want to work, it'll be fine." If social economy is to have any chance of developing there will have to be more stress put on informing society about the essence of social enterprise and opportunities that self-employment creates.

\section{Good practices}


Some examples of good practices:

\section{Social Enterprise 'Być Razem'}

The association 'Być Razem', which means 'Be Together' in English, is engaged in working with homeless and unemployed people in Cieszyn. In 2004, the association received a devastated factory plant after the 'Polifarb' company from the city council for restoration and use. The members of the association created a social enterprise which, on the basis of market rules, can employ people who used the association services or worked in group therapy workshops.

The Foundation for the Social Enterprise Development 'Być Razem' was created in 2007 and runs economic activity. Its task is to acquire funds for the social activity in order to become independent from the public financing, and create job positions for homeless and excluded people - as well as supporting the social cooperatives created by the foundation.

Main aims:

- Reinstate the excluded people into the job market creating new job positions for them.

- Take part in the revitalization of the post-industrial areas of Silesia.

- Participate in the inclusion of excluded people into the job market using work and necessity of contacts with other people as a therapy.

- Promote social entrepreneurship.

The social enterprise comprises of two basic sectors: 
- The workshop sector consists of laundry, tailor, joinery, locksmith, construction work section, kitchen/catering.

- The education and social work sector conducts education, trainings, social work.

Social Enterprise ‘Być Razem’:

- employs 66 people (in all forms of business activity). 19 people found employment in the social enterprise; 8 people in 'New Horizon' social cooperative society; 5 people in 'Supersmak' social cooperative society; 5 women will find job in a recently created tailor social cooperative. The recruitment for workshops and social cooperatives is still ongoing.

- All the employees are hired with employment contracts.

- In 2009 more than 900 people, including 330 long term unemployed, benefited from the assistance of the Foundation for Social Enterprise Development 'Być Razem'. Each year, several dozens of them find jobs on the open market or in economic subjects managed by the foundation. ${ }^{19}$

\section{Baltów - JuraPark}

When the Ostrowiec Steelworks closed in 2001 the unemployment rate in the local area, including Bałtów, was over 30\%. In 2002 a number of Baltów locals registered the Association „Batt”. Together they have started to look for a way to effectively use the region's landscape values which would attract tourists and rejuvenate the locality.

\footnotetext{
${ }^{19} \mathrm{http}: / /$ www.fundacjabycrazem.pl
} 
In 2003 Gerard Gierlinski, from National Geological Institute, found dinosaurs' imprints in the Battów region. The members of the association decided to use the discovery as a tourist attraction.

In 2003 they built a Jurassic Park on the grounds of the former sawmill. The educational path, showing the successive epochs of the Earth's history supplemented by the colorful boards with animals' and plants' descriptions passes through the Park. The main attraction, however, is the 50 natural scale copies of the dinosaurs. At the entrance of the Park there is a spacious place where souvenir stalls are located.

The Bałtów Jurassic Park aims to:

- promote touristic and economic development of the local region: to increase the number of jobs, the development of local enterprises, tourism and catering infrastructures,

- raise awareness about ecological education; to encourage the development of agro-tourism farms and tourism infrastructure with due consideration of local natural resources (river, landscape and local wildlife),

- implement activities for social activation of inhabitants enabling them to pursue an independent development.

In 2007 Ski slope 'Baltavian Switzerland' was created on private terrains leased to the associations. The purpose of such action was to protect employment offseason for 120 people working for the associations. The creation of the ski slope allowed to extend the season and ensured the continuity of the employment, i.e. during the winter time the Kamienna raftsmen are responsible for the operation and maintenance of the slope. 
- Horse riding center 'Realm of Horses'. The center offers cold-blooded Małopolska breeds and huculs (Bieszczady breed). It has been operating since 2005 as an additional tourist attraction.

- The 'Allozaur' company is a type of social integration center to which 'Batt' and 'Delta' associations outsource the tasks to do. It is responsible for serving tourists and providing general work for local people and two associations. The employees of 'Allozaur' ( 25 people) are taking care of local flora, clean tourist routes, parking, river banks. They also organize entertainment events and prepare souvenirs.

- Trainings and advice programs for agro-tourist farms. Financed with the resources of the Human Capital Operational Programme or Civic Initiatives Fund. There are around 25 of such farms operating currently in the locality. In order to improve the quality of their services the association organizes trainings for farm owners in the fields of marketing, promotion and establishing common standards.

Results of all activities

- 120 employees, especially for long-term unemployed people.

- A decline of unemployment in the locality from over $30 \%$ in 2001 to $4 \%$ in 2009 .

- Construction of tourist infrastructure; 5 hotel-catering facilities, 25 agrotourist farms, 5 one person farms.

- Social infrastructure: places for social and cultural activity, open air events. 
- Bałtów is visited by several thousands of tourists (over 500 thousand tourists in 2008 and 2009). ${ }^{20}$

\section{The Bielsko Artistic Association Grodzki Theatre}

The Bielsko Artistic Association Grodzki Theatre was founded in 1999 in the town of Bielsko-Biala (southern part of Poland, $100 \mathrm{~km}$ from Cracow, $60 \mathrm{~km}$ from Katowice, $30 \mathrm{~km}$ from the Czech border). The Association's groups, artists, pedagogues and culture promoters engaged in artistic work with children, teenagers, adults and the elderly from the socially excluded groups.

The latter include physically and mentally disabled persons, people with learning disabilities, children and young people from families at risk, young offenders, victims of alcohol and drug addictions, senior citizens, and all those alienated from the mainstream of social and cultural life.

The Association operates mainly in the Bielsko-Biała region, but also covers the whole area of the southern provinces of Poland. We co-operate with national and international organizations, especially in European projects and publishing initiatives. The Grodzki Theatre is the only non-profit organisation in the region of Silesia with such a complex and wide artistic program to combat social exclusion.

Grodzki Theatre Assocation employs 66 people with disabilities in its two vocational therapy units (sheltered enterprizes): Printing House and Bookbindery in Bielsko-Biała and the Hotel, Conference and Rehabilitation Centre in the beauti-

${ }^{20} \mathrm{http}: / /$ www.ekonomiaspoleczna.pl/x/718029 
ful village of Laliki, Beskidy Mountains. It also runs Occupational Therapy Workshops (arts and life-skills day centre) for 30 people with disabilities in Bielsko-Biała. $^{21}$

\section{Agriculture Vocational Rehabilitation Facility}

Agriculture Vocational Rehabilitation Facility (Rolniczy Zakład Aktywności Zawodowej - RZAZ) was founded over 10 years ago in Stanisławowo in the district of Plock, on the initiative of Blind Relief Committee in Poland, based in New York City and the Foundation "Work for the Blind". The aim of the Facility is to conduct professional and social rehabilitation of employed people with severe and moderate degree of disability.

The tasks of the Facility should be to develop comprehensive steps toward disabled individuals becoming independent professional, social and domestic employees by:

- organizing workplaces tailored to the needs and abilities of people with disabilities;

conducting vocational counseling, job training and other activities towards facilitating disabled people to take up a job in the open labor market;

- providing the necessary assistance to the disabled in the fulfillment of their duties at work and in dealing with personal matters;

${ }^{21} \mathrm{http}: / /$ www.teatrgrodzki.pl/en/ 
- improving the healing and preservation of rehabilitation services for people with disabilities;

- allowing workers with disabilities easier access to culture and recreation, conducting cultural and educational activity;

- conducting individual social work for the benefit of disabled workers;

At the moment the company employs more than 80 people, of whom 58 are handicapped people. ${ }^{22}$

Most of these examples show that the possibility of development of the project largely depends on how deep they are rooted in the local community. It requires social economy entities to have extensive relationships with individuals, institutions and organizations operating in the local environment as well as with local values, norms and traditions.

It is especially important while considering the social criteria of social economy activity. The operation of social enterprise must be focused on supporting and developing local community and promoting the sense of social responsibility on a local level. Another aim is that the production of goods and services should find its market niche. Social enterprise comes into being as a result of the collective activity of people belonging to a given community, sharing the same problems, goals etc.

Referring to social capital there are a number of links within a given community which allow to create joint actions, to combine efforts and to accumulate resources of individuals, institutions, organisations in order to achieve definite goals. Activation of social capital allows to take actions and to pursue goals which may not be implemented outside the network or the cooperation because

\footnotetext{
${ }^{22}$ http://www.fpdn.org.pl/zadania-zakladu.html
} 
no individual, organisation or institution would hold appropriate resources, competences or possibilities of influencing decisions in order to achieve such goals. For the socio-economic development, it is not only the relations within the community that are very important but external connections which link the community to institutions, organisations or other communities and which allow to gain benefits in the form of resources, financial or non-financial support or new markets can also be taken into consideration (R.D. Putnam, 2001; J.S. Coleman 1998; M. Woolcock, D. Narayan: 2007). For activities in the field of Social Economy the ability to diagnose the situation of social capital allows for embedding economic activity into the local market for goods and services.

\section{Conclusions}

Summing up research findings we can conclude that the interest in social economy in Poland, and in the Silesian Voivodship is growing and has become an important element of active social policy. However, as the respondents stressed, the process of institutionalisation of the instruments of social economy in its beginning was obstructed due to some significant barriers like (1) legal constructions, inadequate for the requirements of practice, which regulate actions in the scope of social economy, (2) lack of openness or limited willingness to cooperate on the part of self-government institutions that would support actions taken by entities in this field, although this support is necessary for achieving the assumed goals. After eight years the situation is much better especially in case of legal environment and in the willingness of cooperation from the side of some local governments. However, understanding the importance of SE for local development at the level of local government, especially in small towns and in rural areas is still low. 
It is difficult to assess the functioning of the social economy in Poland. By now, there was a very limited research on the condition of social cooperatives. These bodies, as partially subsidized and supported at the stage of establishment by the authorities, are not subjects to the same standards and conditions as entities of the open market. In view of this situation vulnerability to crisis conditions is limited but at the same time there must be recognition that they are subject to and need to act on the open market, that is closely linked to macro-structural situation.

Most of the social economy entities face problems with running the activity, mainly due to the lack of stable funding, which is connected with the lack of permanent contracts and development strategies and in many cases there is also a lack of marketing strategy. The main problem, however, is the interpersonal disagreement on the level of cooperative members, which very often leads to the dissolution of the cooperative after the period of its financial support.

In the situation of crisis and due to the growing threat of social exclusion resulting from unemployment, social economy in Poland may be an interesting solution from the scope of active social policy but its effectiveness will largely depend on the social roots of the initiative. For establishing and functioning social cooperatives we also need the support of local communities: local government, non-governmental organizations, the cooperative movement, the local business community, which is the result of a considered strategy for local development.Cooperatives cannot be established in a social vacuum.

\section{References:}


Bourdieu, P. (1986): The Forms of Capital. [in:] J.G. Richardson (ed.): Handbook of Theory and Research for the Sociology of Education, New York;

Coleman, J.S (1998): Social Capital in the Creation of Human Capital. American Journal of Sociology. no. 94;

Giza-Poleszczuk, A. \& Hausner, J. (2008): The Social Economy in Poland: Achievements, Barriers to Growth, and Potential in Light of Research Results. Warsaw;

Kaźmierczak, T. (2007): Zmiana w społeczności lokalnej. Szkic o kapitale społecznym w praktyce społecznej i nie tylko. Warszawa;

Kaźmierczak T. Rymsza (2007): Kapitał społeczny. Ekonomia społeczna. Warszawa.

Leś, E. (2005): „Nowa ekonomia społeczna wybrane koncepcje” Trzeci Sektor 2 Fundacja Instytut Spraw Publicznych Warszawa:

Piechowski, A. (2007): Rodowód przedsiębiorczości społecznej w Przedsiębiorstwo społeczne w rozwoju lokalnym [red] E. Leś, M. Ołdak Collegium Civitas Warszawa

Putnam, R. D. (1995): Budowanie sprawnej demokracji. Tradycje obywatelskie we współczesnych Włoszech. Kraków;

Putnam, R. D. (2001): Bowling Alone: the Collapse and Revival of American Community. New York;

Rothman, J. \& Tropman, J. E. (1987): Models of Community Organization and Macro Practice Perspectives: Their Mixing and Phasing [in]: Strategies of 
Community Organization. F.M Cox,J. L. Erlich, J. Rothman, J. E. Tropman (eds) Fourth Ed. F.E. Peacock Publishers Inc. Itasca

Sałustowicz, P. (2006): Koncepcje i funkcje ekonomii społecznej, [in]: P. Sałustowicz, H. Guzowska (ed.), 'Ekonomia społeczna a bezradność społeczna perspektywy i bariery' (BRPO), Warsaw 2006,

Woolcock, M. \& Narayan, D. (2000): Social Capital: Implications for Development Theory, Research, and Policy. "The World Bank Research Observer" no. 2

Zybała A. Rynek pracy społecznie integrujący, zadania dla lokalnych partnerów, „Dialog” no. 2; 


\title{
Development of Social Economy in Romania
}

\author{
Adina Rebeleanu, Livia Popescu
}

\section{Conceptual approaches in the national literature}

The body of literature focusing on social economy opened out in the last ten years. Up till now, neither researchers nor professionals took up debates on the social economy concept. Rather than putting forward their own definitions or questioning the existing ones, most authors adhere explicitly or implicitly to the CIRIEC working definition of social economy (CIRIEC, 2007; Stanescu, 2012; Negrut, 2013; Alexiu, 2013).

\section{Legal definitions of social economy in Romania}

Although in Romania there had been specific types of social economy long before the introduction of the social economy concept (in the middle of the $19^{\text {th } 1}$ century the status of the House of savings and loans was published, which represents the official establishment of the co-operative sector), only in July 2015 appeared a legal act that regulated the field of social economy in Romania: Law 219/2015 on social economy. This law represents the legal framework for the development of social economy, in different ways, which are also regulated through special legislation. For a long time, people were waiting for this piece of legislation. In 2011 the law project was submitted to the Parliament by the Ministry of Labour, Family and Social Protection. The desire to have some regulations focused on the devel-

\footnotetext{
${ }^{1}$ Between 1850 and 1949 different types of co-operative companies were developed, both in urban and rural areas, in various activity fields: co-operative banks, savings, credit and mutual benefit funds, crafts, agriculture.
} 
opment of this field and the attempts to put them into practice, can be identified in some regulations from the beginning of the years 2000 .

Therefore, as a stand-alone notion, social economy was first mentioned in the Romanian legislation by the Governmental Decision No. 829/2002 concerning the adoption of the first National Plan social inclusion and fight against poverty, with further modifications and amendments. The document mentions the need to extend social economy, and to see it as a solution for the improvement of the social sector's efficiency. The concept of social economy is defined based on two pillars. On one hand, economic activities constitute the first pillar. They take in social objectives as well, on condition that economic performance is kept. On the other hand, it is associated with the launch of large infrastructure, urban planning and environmental programs. The investments in these fields can be both economic investments (part of the country's economic development) and social investments in the life quality infrastructure schools, hospitals, etc.). These activities, which fall under social economy, are associated with the economic activity of the population, with income production and thus with a smaller pressure for public social expenses.

The concept of social economy was further restated and detailed in several legislative and strategic documents in the social field.

In 2005 the Romanian common Memorandum for social inclusion was signed. In order to achieve the objectives assumed by Romania on fighting poverty and promoting social inclusion, the Governmental Decision 1827 / 2005 on approval of the implementation of the National Plan for social inclusion and fight against poverty for 2006 - 2008 was adopted. The social economy started to have also an important place in the development of social inclusion policies in Romania. The objective was to create jobs for the benefit of disadvantaged people and to find answers to the identified social needs that were difficult to solve. 
Social economy reappears explicitly on the public agenda in 2008, when it was considered one of the eligible areas for funding under the ESF: it was one of the major intervention fields under the Sectoral Operational Programme Human Resources Development, whose Framework Implementation Document was approved by a joint order of the Minister of Labour, Family and Equal Opportunities and the Minister of Economy and Finance 25 /1169/2008. In September 2008, another major document mentioned social economy in Romania, when the Romanian State made clear commitments regarding the development of this sector in our country. The Romanian Government approved the National Strategic Report on Social Protection and Social Inclusion. Promoting social economy was referred to as the main strategic element in the National Strategic Report on Social Protection and Social Inclusion 2008-2010 of the Ministry of Labour, Family and Social Protection. It was considered to be the main measure that would help achieve the Priority Objective 1 - Increasing the employment of disadvantaged people. Although it was the first time that social economy was conceptualized in a national document, it was not a transversal element and was not present in all the major objectives dealing with the social situation, as it should have been. Its focus was just on increasing the employment of disadvantaged people and thus influenced the profile of the future social economy support. There was no direct connection between social economy and the need to further develop integrated and quality social services programs, as the main means of fighting social exclusion. Not even the Priority Objective 3-Continuing the efforts to improve the living conditions of Roma people- made any references to measures that used social economy. Another major objective of the report concerned health care services. Even here there are no indications about the possible use of social economy mechanisms to ensure the fulfilment of the major targets of this objective. One area with great potential, 
where social economy could play an important role is that of community services and long-term care, residential or homecare.

The Government Strategy on the reform of social work system 2011-2013 aims to streamline the social care system. Starting from the premise that social care represents the "ultimate safety net of the social protection system and its purpose is to protect the people who, because of economic, physical, mental or social reasons, are unable to ensure their social needs, to develop their own capabilities and competencies for social integration", the strategy is focused on reducing the costs of social benefits, reducing the number of beneficiaries, developing social services, and strengthening control; there is too little focus on increasing the access, quality and efficiency of the measures aimed for vulnerable people. None of the six main objectives of the strategy does not refer directly or indirectly to instruments related to social economy, although in some of them (improving quality, increasing activation and participation of beneficiaries, efficient use of funds in the social care system) promoting the social economy could be one of the innovative and efficient solutions. The concept of social economy is not mentioned even once in the strategy.

Only in the National Reform Programme (2011-2013) (pp. 121) new notable references are made concerning social economy. The same programme stated a generous objective for 2011: to finalize "the legal framework for the social economy sector", namely "to regulate the social economy field, to define the concept and to identify the legal entities that are part of this area, as well as to introduce some support and promotion measures for social economy" (pp.121). In 2011 was issued the first legal document that clearly defines social economy Law 292/2011 on social care. The framework Law on social care includes social economy among the "multidimensional actions of the social inclusion process" of vulnerable groups (Art.53, Para.4). The social economy is defined as a sector 
that includes economic activities that, subsidiarily, on condition of maintaining economic performance, include social objectives (Art. 5, letter L, Law 292/2011).

The National Strategy and the Action Plan on social inclusion and poverty reduction for 2014-2020 suggest "the development of social economy to increase employment opportunities for vulnerable groups", through the provision of European funds to support the social economy sector, the elaboration of secondary legislation needed for the sustainable development of social economy, the increased involvement of the non-governmental sector in the social economy and the development of social economy entities operating in the poor/disadvantaged areas.

The latest legislative act is represented by the framework law on social economy (Law 219/2015). The law conceptualizes the social economy, the social economy entities, the principles and objectives of the field, as well as the institutional organization and applicable sanctions in case of infringement. Besides the regulation of the social economy area, the stated objective of the legislative act is to establish measures to promote and support the social economy. Moreover, the law stipulates the responsibilities of local authorities in their effort to support the social economy activities. The objectives of the social economy target employment, development of social services, and strengthening economic and social cohesion. In our opinion, we should keep in mind the perspective of seeing this sector as a stimulating factor for increasing the social inclusion of the recipients of social services, especially in the context of an incomplete social protection system and the business environment's lack of interest to use the human resource represented by the vulnerable populations. There is a close link between social work and social economy, legally formalized. The framework law on so- 
cial work ${ }^{2}$ defines and emphasizes the role of social economy in promoting the social inclusion of vulnerable groups and operationalizes the concept of vulnerable group. The Law of social economy refers to the vulnerable group so as defined in Social work law, mentions the importance of the development of social economy entities as an inclusive approach with a high development potential of the existing social services, and the creation of a public-private partnership in supporting and promoting the local communities development.

The social economy represents "all activities organized irrespective of the public sector, whose purpose is to serve the general interest, the interests of a community and/or personal patrimonial interests by increasing the employment of persons belonging to the vulnerable group and / or the production and supply of goods, services and/or works" (Art.2 Para.1, Law 219/2015). The Framework Law operationalizes two forms of organization and functioning: the social economy company and the social insertion company. The first form is defined by reference to any legal entity of private law carrying out activities of social economy, according to the principles of social economy (priority given to the individual and to social objectives, solidarity and collective responsibility, democratic control, voluntary and free association, convergence between the interests of associate members and the general interest of the community, a distinct legal personality, allocating a part of the profit to achieve the general interest objectives. The law also provides the conditions for granting the certificate of social

\footnotetext{
${ }^{2}$ A vulnerable group represents individuals or families who are at risk of losing their ability to meet the needs of daily living because of illness, disability, poverty, drug or alcohol abuse, or other circumstances that lead to economic and social vulnerability. The categories of vulnerable persons mentioned in the law are families and single people without income, homeless, victims of trafficking or domestic violence, children, detainees, persons suffering from chronic diseases, persons with disabilities, single parents, Roma, people living in isolated communities, young people aged over 18 who have to the foster care centers.
} 
enterprise. The category of social companies encompasses credit cooperatives, co-operative societies, associations and foundations, employees and pensioners' mutual funds, agricultural companies and any other legal entities which, according to the legal documents establishing and organizing the entity, meet cumulatively the definition and principles of economy social. The social insertion company, enshrined separately for the first time in the framework law on social economy, is the social enterprise that meets all the following conditions: always has at least $30 \%$ of staff belonging to the vulnerable group and aims to combat marginalization, exclusion, discrimination and unemployment among disadvantaged people. According to the legal provisions, the vulnerable group membership has to be legally proven and the social economy enterprises must provide accompaniment measures for those employed, so as to support their professional and social insertion. These measures require cooperation between the social insertion companies and the public social care services, the employment agencies, and the organizations that offer integrated social, medical, and psychological services. In other words, there is a need for a holistic approach to the social inclusion of vulnerable people, by supporting collaboration among all stakeholders: public authorities, decentralized services, NGOs, private organizations, businesses, training and employment agencies, higher education and research institutions, etc., involved in training specialized personnel.

We should mention the fact that the social insertion company should not be confused with the protected units, which are recognized forms of social enterprise in our country, developed mainly since 2007.

The protected unit is represented by the "public or private economic operator, with its own management, in which at least $30 \%$ of the total number of employees that have an individual employment contract are disabled people" (Law $448 / 2006$ on the protection and promotion of the rights of persons with disabili- 
ties (republished), art.5, pt.29). According to the Decision 268/2007 approving the Methodological Norms for the application of Law no. 448/2006 on the protection and promotion of the rights of persons with disabilities, the protected units are those entities which cumulatively meet the following conditions: a) economic operators with legal personality, regardless of the form of ownership and organization, in which at least $30 \%$ of the total number of employees with individual employment contract are people with disabilities; b) departments, workshops or other structures within economic operators, public institutions or NGOs, that have their own management and at least $30 \%$ of the total number of employees is represented by people with disabilities; c) physical disabled person authorized by law to conduct independent economic activities, including the family association which includes a disabled person. This also includes individuals with disabilities, authorized under special laws, which operate both individually and in one of the profession's organized forms (art.44, GD. 268/2007). Under Law 448/2006, the protected units can be: a) with legal personality and b) with no legal personality, with its own management, organized in departments, workshops or other structures within economic operators, public institutions or NGOs, as well as those organized by the disabled person authorized by law to perform independent economic activities (art.80, para.(2)). Many nongovernmental organizations engaged in supporting and promoting the social inclusion of people with disabilities, have developed protected units, using structural funds. After the funding period ended, some of the protected units have managed to become structures on their own, with legal personality, others remained in the structure of the associations or foundations where they were created, while others have closed in the absence of legislative support meant to create conditions for local sustainability. Regarding the establishment of protected units, a first aspect that has to be mentioned concerning the way in which 
the protected units are created is that the legislation in force regulates their authorization, not their establishment, which means that the term protected unit does not represent a distinct and standalone type of organizations, governed by a special law, but rather a statute granted to a variety of legal entities (companies, associations and foundations, cooperatives, self-employed persons), following an authorization procedure (Order 1372/2010 approving the Procedure for authorizing protected units).

As regards the authorization of protected units, Order 1372/2010 (art. 4) lays down the conditions an entity must satisfy in order to be authorized as a protected unit: own management; at least $30 \%$ of the total number of employees to be people with disabilities; products or services offered for sale should be made by the people with disabilities employed, except those provided by protected units established within organizations of disabled people. One can notice the importance given to the direct involvement of the employees with disabilities, an essential component in view of the purpose of establishing protected units, namely to protect and promote the rights of persons with disabilities, aiming for their social integration and inclusion, in terms of equality of rights and obligations at society level (Law 448/2006, art.3); this is defined as "all activities carried out fully or partially by a disabled person in order to obtain a marketable product or to provide a service" (Decision 89/2010 amending and completing the Methodological Norms for the application of Law no. 448/2006, art.43, para.4), a feature that is certified, according to the law, by the individual employment contract of a disabled persons, by the job description or other documents issued by the management of the protected unit.

The law on social economy does not repeal the regulations in force that include provisions for the organization and functioning of the various types of social enterprises, but makes some remarks about the need to address in a common 
manner the framework law with the regulations governing the functioning of cooperatives, associations and foundations, mutual funds, agricultural companies, etc. For each structures of the social economy there are specific regulations, which is why we are going to present only synthetically some of the most important laws.

The cooperative company, one of the oldest forms of organization of social economy in Romania is legally representing "an autonomous association of natural and/or legal persons, established on the basis of their freely expressed consent, in order to promote the economic, social and cultural interests of the cooperative members and is jointly owned and democratically controlled by its members in accordance with cooperative principles." (Law no. 1/2005 on the organization and operation of the cooperative, art.7, para.1). Cooperatives are considered to be "the most important economic agent of social economy" (Barea \& Monzon, 2006, in Petrescu, 2011, p.18) and they have an important role in mitigating market failures due to their specificity: they are operating in locations that are not attractive for private companies; they provide employment for people who have difficulties to enter the labor market; they make purchase and sale decisions based on the established social goals (Petrescu, 2011). A general legal framework for cooperatives in Romania was established by the adoption of Law no.1/2005 on the organization and operation of the cooperative, which also represents the moment when the legislation on handicraft cooperatives and consumer cooperatives was unified (Petrescu, 2011). The cooperative principles are regularly reviewed and renewed by the International Cooperative Alliance; they are fully included in Law 1/2005 on the organization and operation of cooperatives (art.7 para. 3: the principle of voluntary and open association; the principle of democratic control of cooperative members; the principle of economic participation of the cooperative members; the principle of autonomy and independ- 
ence of cooperative companies; the principle of education, training and information of cooperative members; the principle of cooperation among cooperative companies; the principle of concern for the community. Law 1/2005 (art. 4) regulates the establishment of cooperative companies in the following forms: craft cooperatives, consumer cooperatives, recovery cooperatives, agricultural cooperatives, housing cooperatives, fishing cooperative, transport cooperatives, forestry cooperatives; it is also allowed to establish other forms of cooperative companies, in compliance with the law.

In Romania, handicraft cooperatives represent an attribute of the urban area; the first handicraft cooperative was founded in 1879 in Bucharest (Petrescu, 2011). Handicraft cooperatives are "associations of individuals engaged in joint production activities, trading goods, execution of works and service provision that contribute directly or indirectly to the development of the handicraft activities of the cooperative members" (Law 1/2005 on the organization and operation of cooperatives, art. 4 a).

The credit cooperative is "a credit institution established as an autonomous association of natural persons united voluntarily to meet the common needs and aspirations of economic, social and cultural nature, whose activity is developed mainly on the principle of mutual help among its cooperative members" (Emergency Ordinance 99/2006 on credit institutions and capital adequacy (with further amendments and modifications), art.334, let. a), with activities specific to credit institutions (of which the best known are those of lending and of attracting deposits). At present, the credit cooperatives in Romania, are known as "cooperative banks", at the end of a long and extensive restructuring process, begun in 2000 by the Government Emergency Ordinance 97/2000 on credit cooperatives. This ordinance has forced credit cooperatives established under Law 109/1996 to opt either for a reorganization in order to operate under a cooperative network 
(the CREDITCOOP network, authorized by the National Bank of Romania in 2002) or for a transformation into a commercial bank.

Consumer cooperatives are "associations of natural persons engaged in common activities of supply for the cooperative members and for third-parties of products that they buy or produce, and also provide services for their members and for others" (Law 1/2005 on the organization and operation of cooperatives, art.4, letter $b)$.

The establishment of agricultural cooperatives in Romania, is governed by two laws: Law 566/2004 regarding agricultural cooperative that regulates only the social economy field, and Law 1/2005 on cooperatives that has provisions regarding the possibility of establishing recovery cooperative companies and agricultural cooperative companies.

The agricultural cooperative is "an autonomous association of natural and/or legal persons, a legal entity of private law established on the basis of the freely expressed consent of the parties, in order to promote the interests of cooperative members in accordance with cooperative principles, which is organized and operates in accordance with the law" (Law 566/2004, art.2). Agricultural cooperatives can be established in the following forms: agricultural service cooperatives; procurement and sales agricultural cooperatives; agricultural cooperatives processing agricultural products; manufacturing and small industry agricultural cooperatives; land, forestry, fisheries and livestock management agricultural cooperatives; finance, mutual assistance and agricultural insurance agricultural cooperatives.

C.A.R. credit unions are assimilated into the category of mutual funds or credit unions, the main role being to collect funds from its members, in a social fund, and to offer low interest loans to its members. In Romania, these social economy units, are divided into two categories, which are regulated by different laws, but 
which have a common legislative framework: the Emergency Ordinance 26/2000 on associations and foundations (republished). It distinguishes between: a). Employees C.A.R. credit unions- operate under Law 122/1996 on the legal regime for employees credit unions and their union (republished). The purpose of these entities is to support and assist their members by granting loans with interest. The interest on loans returns to the members' social fund, after deducting statutory expenditures. Its members can be only persons that are employed.

b). Pensioners and socially assisted persons C.A.R. - operate under Law 540/2002 on pensioners' credit unions. There are nonprofit organizations established to support and assist their members through loans repaid with interest, grants and some funeral expenses. They may also undertake other related activities: cultural, artistic, touristic, and services offered at discounted rates using the work of pensioners. Among the activities that can be organized in these structures we can mention: organizing stores selling food products at procurement price, managing houses of rest and treatment, organizing workshops for the repair of various household appliances, clothing, footwear, woodwork and others, providing medical services at reduced tariffs that cover materials cost and specialized staff salaries in individual medical and dental practices, operating according to laws in force. Members may be pensioners, social welfare recipients and members of their families.

In Romania, the associations and foundations are defined as "legal entities of private law whose main purpose is non-patrimonial, but may also undertake economic activities, directly or through the establishment of companies" (Ordinance 26/2000 on associations and foundations, approved by Law 246/2005). In the Romanian legislation, the nongovernmental organization was first defined in the Ordinance 8/1997 on stimulating research, development and innovation. It is defined as "the Romanian legal entity of public or private law, of community 
interest, non-political, non-profit, recognized under the law as having legal personality, and which is not invested with the exercise of state authority and is not part of the public administration system "(art. 6, para. v). Afterwards, the Ordinance $26 / 2000$ on associations and foundations, regulated the establishment, organization and functioning of associations and foundations, as the predominant form of private business, nongovernmental and non-patrimonial. The following table shows comparative features of associations and foundations, as conceptualized by the regulations in force:

\begin{tabular}{|l|l|l|}
\hline Common & Associations & Foundations \\
\hline characteristics & $\begin{array}{l}\text { - legal personality is obtained through registration into the Associa- } \\
\text { tion and Foundation Register } \\
\text {-the articles of incorporation have the same content } \\
\text {-two or more associations or foundations may establish a federation; } \\
\text { the associations or foundations that form a federation keep their legal } \\
\text { status, including their own assets } \\
\text { - revenues are represented by: a) membership fees, b) interest and } \\
\text { dividends from investments, according to the law, c) dividends from } \\
\text { companies set up by associations, foundations and federations, d) } \\
\text { income from direct economic activities, e) donations, sponsorships or } \\
\text { legacies, f) resources from the state or local budgets and g) other } \\
\text { revenues provided by law. } \\
\text { - the associations, foundations and federations can establish private } \\
\text { companies; dividends resulted from the activities of these companies, } \\
\text { unless reinvested in the same company must be used for achieving the } \\
\text { purpose of the association, foundation or federation. }\end{array}$ \\
\end{tabular}




\begin{tabular}{|c|c|c|}
\hline Legal definition & $\begin{array}{l}\text { - a legal entity set up by three or } \\
\text { more people who, according to an } \\
\text { agreement, put together, with no } \\
\text { right of return, their material, } \\
\text { knowledge or work contribution } \\
\text { in order to develop activities for } \\
\text { the general, community or own } \\
\text { non-patrimonial interest. }\end{array}$ & $\begin{array}{l}\text { - the legal entity set up by one } \\
\text { or more individuals who, based } \\
\text { on a legal act inter vivos or } \\
\text { upon death, establish a patrimo- } \\
\text { ny designed, permanently and } \\
\text { irrevocably, for achieving an } \\
\text { objective of general interest or, } \\
\text { where appropriate, of some } \\
\text { communities' interest. }\end{array}$ \\
\hline Constituents & $\begin{array}{l}\text { - patrimonial assets must be worth } \\
\text { at least a minimum gross salary }{ }^{3} \text {, } \\
\text { on creation of the association, and } \\
\text { is made up of the associates' cash } \\
\text { and/or in kind contributions } \\
\text { - subsidiaries may be established, } \\
\text { as territorial structures, with a } \\
\text { minimum of } 3 \text { members, govern- } \\
\text { ing bodies and a distinct patrimo- } \\
\text { ny from that of the association; } \\
\text { Subsidiaries are entities with legal } \\
\text { personality } \\
\text { - branches may be set up, as terri- } \\
\text { torial structures with no legal } \\
\text { personality }\end{array}$ & $\begin{array}{l}\text { - the foundation's initial patri- } \\
\text { monial assets must include } \\
\text { goods in kind or in cash, whose } \\
\text { total value should be at least } 100 \\
\text { times the minimum gross salary, } \\
\text { on creation of the foundation } \\
\text { (article } 15 \text { par. } 2 \text { ) } \\
\text { - subsidiaries may be set up, as } \\
\text { territorial structures, based on } \\
\text { the board's decision; subsidiar- } \\
\text { ies may be led by their own } \\
\text { board of directors, composed of } \\
\text { at least } 3 \text { members }\end{array}$ \\
\hline
\end{tabular}

Source: Ordinance 26/2000 on associations and foundations

Table 1.: Comparative presentation of the defining characteristics of associations and foundations in Romania

\footnotetext{
${ }^{3}$ At present, the minimum gross salary in Romania is 1050 Ron (approximately 230 Euro)
} 


\section{Political context and the dynamics of social economy components}

The importance and need of a social economy sector in Romania were approached in a rather consensual way by both political parties and organizations. However, representatives of various forms of the social economy expressed some time differing views. While representatives of cooperative sector endorsed the preservation of its specific legislation, those speaking for the NGOs were favourable to an all encompassing law on social economy.

In 2011, the draft of the law on social economy was submitted to the public debate by the Ministry of Labour, Family and Social Protection. It raised harsh criticism particularly from the representatives of the social economy entities. They disagree with the interpretation of the sector as aiming primarily at the social inclusion of the vulnerable groups. The new draft of the law reflected a more balanced view on the social economy and allowed a positive outcome of the 2012 public debate and granted the support of all stakeholders in the pursuing of the legislative process (Stănescu, 2013: 16).

The analysis of the social economy entities in dynamics shows an important increase $(150 \%)$ of the number of associations and foundations between 2000 and 2010. Similarly, the number of employees in the non-profit/nongovernmental sector rose from 19.172 to 60.947 in the respective period. According to the number of units and employees, this is by far the most important form of the social economy in Romania. However, the NGOs with economic activities represent merely one tenth of the total and employ one third of the total employees in the sector. From 2000 to 2010, mutual funds (C.A.R.) followed an ascendant trend as well, with their number increasing by $150 \%$ and their staff by almost $50 \%$. The dynamics of the cooperative sector shows an opposite trend. While the number of units remained constant, the number of employees dropped by two thirds: from 93.232 in 2000 to 34.597 in 2010 . Moreover, the proportion 
of cooperatives that obtained a return decreased in the same interval of time. Among consumption and craft cooperatives, the downturn is constant (Petrescu, Stănilă, 2013: 61-62).

\section{Innovation and good practices}

\section{Mozaic SRL ${ }^{4}$ Bucureşti}

For the national context, a category of vulnerable people in terms of access to the labor market is represented by the persons with disabilities.

Peoples Development Foundation (PDF) is a nongovernmental organization created in 1996 that provides social, educational and professional integration opportunities for people in social risk situations. $\mathrm{PDF}^{5}$ has the headquarter in Bucharest, three subsidiaries in the country (Arad, Cluj and Dambovita counties) and operates in four Romanian regions (Bucharest Ilfov, West, North - West, South - Muntenia). By successfully combining social work and social economy, the PDF intervenes in an integrated manner at the level of communities with three main objectives: preventing early school leaving; promoting sustainable employment; and the development of social economy initiatives. From the clear achievements of the PDF, between 2011 and 2013, we mention: the provision of educational services for over 1,200 children and their families, of social services for more than 250 people from vulnerable groups, of stimulating employment services for more than 4,950 unemployed persons and people looking for a job. Based on the social economy concept, and in order to employ people with special needs, the PDF founded in 2012 two social enterprises: the Mosaic SRL

\footnotetext{
${ }_{5}^{4}$ Limited liability company (LLC), in accordance with the national regulations in force.

${ }^{5}$ www.fabricademozaic.ro
} 
Project (Bucharest) and the PDF Store Team SRL (Cluj), and during the year founded 2 more companies, one in St. Ana, Arad county, and one in Cojsca, Dambovita County.

The Mozaic ${ }^{6}$ project is a company that was created in response to the needs of young people in vulnerable situations (disability and post-institutionalization make it difficult for them to integrate into the social and professional life; most of them have a low educational level, a strong feeling of abandonment, lack family support, etc.), looking for a job. It is a social economy company, created in a project that was co-financed by the European Social Fund. It has two associates: Simona Carobene and the Peoples Development Foundation. It is an authorized protected unit that produces ceramic, sandstone, natural stone and other materials mosaic. Mrs. Simona Carobene, the manager of the company, referring to the purpose and long-term vision for establishing Mosaic, said : "We did not want to create a "protected workshop" for people with disabilities (for minor, handwork activities, which are not sustainable in the long term), but we wanted to lay the foundations of a company that provides real employment for disadvantaged people and that in time is able to become a sustainable company" (Interview with Mrs. Simona Carobene conducted by Pascaru 2013:151). Young employees participate in the entire production process for making mosaics and receive education and support for their work. They are actively involved in the creation of models, development of new product lines, promotion and marketing activities (for instance, one of the young employees is the company's spokesper-

\footnotetext{
${ }^{6}$ The presentation of Mozaic SRL is done based on the information provided by its official website, an interview with Mrs. Simona Carobene conducted by Gheorghe Pascaru in 2013 and published in the Social Economy Magazine, and information generously offered by Mrs. Carobene, during various events on the social economy, organized in Cluj-Napoca. Many thanks to Mrs. Carobene for her continuous support and involvement in the development of social economy.
} 
son and is involved in delivering presentations and giving declarations when customers or potential partners visit the factory). It currently has 10 employees, 6 young people, 4 technicians and 5 young people in training. "For me is the first time I have a job for so long, and that's because you trusted me", said one of the young people from Mosaic Factory.

In parallel with the production of the mosaic, the Mosaic Project occasionally gives customers packaging and product assembly services; the services are aimed specifically at companies with over 50 employees, who are interested in working with a protected unit under Law 448/2006. As far as competition is concerned, related to mosaic production, in Romania there is only one factory with similar activity. Mosaic's prices are 5\% lower than the competition, providing the same quality of products, but with additional facilities related to reduced order completion time and the status of protected unit. The values promoted by Mosaic are focused on the centrality of the person, the person is actively and directly involved, confidence in the person's ability to integrate professionally, equal opportunities, creativity and flexibility, and customer-satisfaction by generating quality products. It has stable clients at home and abroad, and the mosaic products made in the enterprise are mounted in institutions of impact (e.g. Casino Marriott, Orange Romania, the National Stadium, Volksbank Romania). There is an ongoing concern to increase the number of customers by purchasing new machines that allow the creation of new models, including customized artistic mosaic, to be exposed at different distributors. In 2014, Mosaic recorded a turnover 38\% higher than in 2013 and made profit. In 2015 the turnover will increase again by $20 \%$.

The social economy model developed by Mosaic highlights the importance of valorizing the resources from the territory, the partnerships in the start-up phase of a social enterprise and the fundamental role of the entrepreneur to create, and 
then develop the social enterprise. "Our certainty is the awareness that educating young people to work is not an assistance deed but an investment for our society. The so-called "human capital" does not represent only the excellence level, but there is in every human being, even in those that are "different". The so-called limits of each person (physical, mental, of social conditions or others) are nothing but an extra challenge, in order to give each person something that helps them to grow, to develop, to be the protagonist of their own human adventure" (Simona Carobene,2015,May).

The Mosaic SRL Project is an example of a protected unit, which combines economic and social goals, that did not stop functioning, despite the obstacles encountered, that learned and understood that a social enterprise needs to be sustainable, through the importance given to the customer, the development of marketing, sale and market analysis strategies, and last but not least the change of mentalities. It is a successful protected unit, well-known and often given as an example of good practice for the construction of a feasible protected unit, which in Romania is assimilated to the social economy structures.

\section{Mesteshukar ButiQ (MBQ $)^{7}$}

According to the Commission Staff Working Document "Elements for a Common Strategic Framework 2014 to 2020 for the European Regional Development Fund the European Social Fund, the Cohesion Fund, the European Agricultural Fund for Rural Development and the European Maritime and Fisheries Fund" social economy and social enterprises should be promoted through: "capacity-building and support structures for the promotion of social enterprises, in particular through social entrepreneurship education and training, networking, the development of national or regional strategies in partnership

\footnotetext{
${ }^{7}$ Many thanks to Mrs. Andreea Gavrilovici, MBQ Manager, for the information provided.
} 
with key stakeholders, and the provision of business development services and easier access to finance and mobilization of funds to support initiatives in the social economy and social entrepreneurship."

Thus, in compliance with the Law on social economy from July 2015, social economy is assimilated to the economic sector. The aim was to increase the employability of the persons belonging to vulnerable groups and to facilitate their access to the community's resources and services.

Most often, Roma people are assimilated to the vulnerable group and the statistics for Romania confirm their high risk to poverty and social exclusion. The lack of access to jobs, proper housing conditions, education and healthcare services are only some of the social problems with which Romanian Roma people are confronted. The Romanian decision makers have tried to tackle these problems through passive and active social protection measures (see the First Romanian Government Strategy for Improving the Condition of the Roma, the Inclusion Strategy 2014-2020, etc.). Although some progress has been made, the Romanian Roma minority remains a population that is facing several obstacles when it comes to access to employment, education and proper living conditions. Many of these obstacles depend upon different structural mechanisms in the society. Taking into account this context, the social economy allows for a targeted focus on the needs of the Roma community: organizing professional qualification and training programs based on the local market demands; evaluating professional competencies that were not gained through formal training in order to facilitate the inclusion on the labor market of those belonging to vulnerable groups, especially the Roma population; encouraging the participation of women in professional trainings and facilitating their employment (including Roma women); providing professional counseling services for those seeking for a job (including the Roma community members) in order to help them reintegrate in 
the society (support for preparing their $\mathrm{CV}$ and for preparing the job interview); capitalizing the crafts, encouraging entrepreneurship among Roma community by supporting non-reimbursable fund and identifying potential beneficiaries.

That is why we have decided to present the MesteshukarButiQ store, a model of innovative promotion means of the traditional Roma crafts. The mobile shop from Cluj is part of the ButiQ. $7^{8}$ project of the Romano ButiQ Association in collaboration with KCMC - K Consulting Management and Coordination and the Humanitarian Association Together for Them from Baia Mare.

Mesteshukar ButiQ (MBQ) is a network of social economy enterprises and an active supporter of Roma traditional crafts. It has been active in Cluj since 2012, organizing temporary exhibitions and live craft demonstrations. It opened in Cluj the first mobile shop in Romania, a shop that gathers together works created by Roma craftsmen together with well-known international designers (from Romania, Austria, Sweden). MesteshukarButiQ managed to bring a fresh vision on Roma crafts and revive traditional products and objects with contemporary design. Intended to meet contemporary needs of life reconnection and protecting of the natural environment, products and services offered by MesteshukarButiQ involve a clean raw material, knowledge of the craft passed through a long trial time, skillful hands and an immediate utility.

MBQ provides premium lifestyle products with a story and design that stands out in any context, using a blend of centuries old techniques combined with contemporary design.

\footnotetext{
${ }^{8}$ You can find information about the ButiQ.7 project at: http://butiq7.romanobutiq.ro/ despre-noi/, and about former projects undertaken by KCMC, as well as information about craftsmen, handicraft cooperatives, former projects to the Mesteshukar ButiQ at: : http://www.mesteshukar.ro/i_acasa.asp? SMID=36\&ARTID=91
} 
Between 2010 and 2011, the Romano ButiQ Association undertook a series of projects with the goal to rebuild the connection between the skills of the Roma craftsmen and the current market needs, as well as to promote the Roma culture and traditions. Between 2011 and 2012, as partner of KCMC, they organized the Romano ButiQ Itinerant Workshop, and in 2015 they opened stores in Bucharest, Cluj-Napoca and Sibiu.

At present, the store has a network of over 50 active craftsmen and is currently working with a team of 4 international designers on product development. They are supported by the ERSTE Foundation, CCFD Terre Solidaire and OMV Petrom.

MBQ creates revenue by selling lifestyle products such as: jewelry, clothes and home-décor objects. Every object sold generates direct income for Roma craftsmen. MBQ is currently addressing the general home-décor and fashion market. MBQ are targeting middle and upper class consumers with an interest in tradition, crafts and design, and also the private businesses.

MBQ has exhibited at large scale design events such as Romanian Design Week and Vienna Design Week. MBQ sell the products using several channels: stores (in Bucharest, Cluj and Sibiu), an online store (mbq.ro), direct sales, resellers and fairs. In Cluj-Napoca, MBQ launched a pop up store which displays objects made by Roma craftsmen in collaboration with designers, as well as elements of Roma tradition and culture.

MBQ future strategies aim at increasing the production capacity, along with a continuous development of new products, and at identifying new distribution partners.

Recently, the Mestesukar ButiQ had several initiatives in order to increase their product portfolio and to support the craft Roma community all over the country. One example is the contest they launched, in which they invite students and 
professionals to create product concepts that could be afterwards produced in the Roma craftsmen workshops and then sold in the Mesteshukar ButiQ network. The contest aims at involving the designers and architects from Cluj in this process of integrating the craft products in the daily life of Cluj, based on the premise that a unique design might increase the public interest in handmade objects that use natural materials and thus also increase sales. Moreover, the exhibition called "Products with stories from the heart of Transylvania" brings together objects made by Roma craftsmen belonging to different guilds from Transylvania and wishes to increase the public awareness concerning Roma traditional crafts.

\section{Final remark}

The two social economy structures presented managed to show and are still proving that the social economy entities represent a desirable goal: people considered vulnerable and recipients of social benefits are and can become much more than that: taxpayers due to the remunerated activities they carry out, they are actively involved in developing the community they live in and they help change the mentality, at a social level, regarding the work value of people belonging to vulnerable groups. 


\section{References}

Alexiu, M. (2013): Economie socială şi antreprenoriat [Social economy and antrepreurship] in D. Buzducea (coord), Economia Socială a grupurilor vulnerabile [Social Economy of the vulnerable groups], Iași: Polirom

CIRIEC. (2007): The Social Economy in the European Union, Bruxelles: European Economic and Social Commitee, www.eesc.europa.eu/resources/docs/qe30-12-790-en-c.pdf (20.12.2015)

Guvernul României, Ministerul Muncii, Familiei şi Protecţiei Sociale. 2011. Memorandum. Strategia privind reforma în domeniul asistenţei sociale. [Governmental Strategy regarding the reform of the social work system, 20112013] Nr. 20/5541/D.N.A. $3^{\text {rd }}$ Mars 2011

Guvernul României. 2011. Programul naţional de reformă (20112013).[National Reform Programme (2011-2013)], Bucureşti

Guvernul României, Ministerul Muncii, Familiei şi Protecţiei Sociale. 2014. Strategia naţională şi Planul de Acţiune privind incluziunea socială şi reducerea sărăciei pentru perioada 2014-2020 [National Strategy and the Action Plan on social inclusion and poverty reduction for 2014-2020],

Hotărârea Guvernului nr. 829/2002 privind adoptarea primului Plan naţional antisărăcie şi de promovare a incluziunii sociale [Government Decision No. 829/2002 concerning the adoption of the first National Plan social inclusion and fight against poverty]. Monitorul Oficial, [Romanian Official Gazette] issue 662/ 6.09 .2002 
Hotărârea Guvernului nr.1.827/2005 privind aprobarea Programului de implementare a Planului naţional antisărăcie şi promovare a incluziunii sociale (PNAinc) 2006 - 2008 [Government Decision 1827 / 2005 on approval of the implementation of the National Plan for social inclusion and fight against poverty for 2006 - 2008]. Monitorul Oficial al României [Romanian Official Gazette], issue 64/ 24.01.2006

Hotărârea Guvernului 268/2007 pentru aprobarea Normelor metodologice de aplicare a prevederilor Legii nr. 448/2006 privind protecţia şi promovarea drepturilor persoanelor cu handicap [Government Decision 268/2007 approving the Methodological Norms for the application of Law no. 448/2006]. Monitorul Oficial al României [Romanian Official Gazette], issue 233/04.04.2007

Hotărârea Guvernului nr. 89/2010 pentru modificarea şi completarea Normelor metodologice de aplicare a prevederilor Legii nr. 448/2006 [Government Decision 89/2010 amending and completing the Methodological Norms for the application of Law no. 448/2006]. Monitorul Oficial al României [Romanian Official Gazette], issue 103/ 15.02.2010

Legea nr.292/2011 a asistenţei sociale [Law no.292/2011 regarding the social work]. Monitorul Oficial al României [Romanian Official Gazette], issue $905 / 20.12 .2011$

Legea $n r .219 / 2015$ privind economia socială [Law no.219/2015 regarding the social economy]. Monitorul Oficial al României [Romanian Official Gazette], issue $561 / 28.07 .2015$

Legea 448/2006 privind protecţia şi promovarea drepturilor persoanelor cu handicap [Law 448/2006 on the protection and promotion of the rights of per- 
sons with disabilities]. Monitorul Oficial al României [Romanian Official Gazette], issue 1006/ 18. 12.2006

Legea $n r$. 1/2005 privind organizarea şi funcţionarea cooperației[Law 1/2005 regarding the organization and operation of cooperatives]. Monitorul Oficial al României [Romanian Official Gazette], issue 172/28.02.2005

Legea cooperaţiei agricole $n r$. 566/2004 [Law 556/2004 agriculture cooperative]. Monitorul Oficial al României [Romanian Official Gazette], issue $1236 / 22.12 .2004$

Legea $n r$. 540/2002 privind casele de ajutor reciproc ale pensionarilor [Law 540/2002 on pensioners' credit unions ].Monitorul Oficial al României [Romanian Official Gazette], issue 723/3.10.2002

Legea nr. 122/1996 privind regimul juridic al caselor de ajutor reciproc pentru salariaţi şi al uniunii acestora [Law 122/1996 on the legal regime for employees credit unions and their union]. Monitorul Oficial al României [Romanian Official Gazette], issue 262/ 25.10.1996

Ministerul Muncii, Familiei şi Protecţiei Sociale. 2008. Raportului Naţional Strategic privind Protecţia Socială şi Incluziunea Socială, 2008 - 2010 al National Strategic [Report on Social Protection and Social Inclusion 20082010], Bucureşti

Ministerul Muncii, Familiei şi Protecţiei Sociale. 2010. Ordinul 1372/ 2010 privind aprobarea Procedurii de autorizare a unitătilor protejate[Order 1372/2010 approving the Procedure for authorizing protected units]. Monitorul Oficial al României [Romanian Official Gazette], issue 676/ 05.10.2010 
Negruț, A. (2013): Capital social, economie socială și dezvoltare locală [Social capital, So cial economy and local development], in Petrescu. C (coord), Economia socială în contextul dezvoltării locale [Social Economy in the context of the local development), Iași: Polirom

Ordonanţa de Urgenţă a Guvernului nr. 26/2000 cu privire la asociaţii şi fundaţii. [Government Ordinance 26/2000 on associations and foundations]. Monitorul Oficial al României [Romanian Official Gazette], issue 39/31.01.2000

Ordonanţa de Urgenţă a Guvernului nr. 99/2006 privind instituţiile de credit şi adecvarea capitalului. [Emergency Ordinance 99/2006 on credit institutions and capital adequacy] Monitorul Oficial al României [Romanian Official Gazette], issue 1027/27.12.2006

Pascaru Gh. (2013): „Interviu cu Doamna Simona Carobene, Admnistratorul SC Proiect Mozaic SRL” [,Interview with Mrs.Simona Carobene, Manager of SC Project Mozaic SRL"] in Revista de economie socială [Journal of Social Economy], vol. III/Nr.5 2013:151-166, Iaşi: Editura Hamangiu

Petrescu, C. (2011): Mişcarea cooperatistă în România 2011 - dimensiuni, performanţe, tendinţe, provocări. Raport preliminar. [Cooperative movement in România - dimensions, performances, trends and challenges. Preliminary report]. PNUD România.

Petrescu, C. \& Stănilă, G. (2013): Entitățile de economie socială din Româniaanaliză comparativă pe baza datelor cercetării sociologice [Social economy entitities in Romania- comparative analysis based on sociological research data] in C. Petrescu (coord), Economia socială în contextul dezvoltării locale [Social Economy in the context of the local development), Iași: Polirom 
Stanescu, S. (coord). (2012): Raport de deschidere in cadrul proiectului Modelul Economiei Sociale in Romania [Opening Report of the project The Model of Social Economy in Romania, http://profitpentruoameni.ro/wpcontent/uploads/2012/01/Raport-de-Deschide-privind-Economia-Sociala1.pdf (20.12.2015) 


\section{Social Economy, Social Work in Hungary}

\section{László Patyán}

\section{Preface}

This study introduces the basic concepts, national history and regulations of social economy in Hungary. First it should be stated that there is no universally accepted definition of social economy in Hungary. Changes in the concept reflect the national and European system of values with respect to social economy. The second part of the study focuses on the relationship of social work and social workers to the classic concept of social economy.

\section{What is social economy and what is not social economy? Interpretation frameworks of social economy}

Conceptualizaitons of social economy and its components may change over time, as well as on the basis of national or social ideologies. Different approaches define what is included in this concept depending if they can be connected to the sector or if characteristic functions and areas can be related to social economy. This study attempts to define the elements of this concept relative to national situations. 


\section{Third sector theory}

Social economy is traditionally defined as third sector that is a separate sector from the market/private and state sectors. The social economy sector typically develops through community roots and motivation to primarily satisfy needs arising in the community.

According to this conceptualization system it occupies an intermediate position between the state and the market, has both an economic function and a social mission serves the public interest. Any profit gained from economic activity is not divided among shareholders as would occur in a for profit corporation (Frey, 2007). Csoba has a different view and considers the social embeddedness of the organizations of the social economy as the root for interpretation (Csoba, 2007:16). In this approach the function and the organizations in the sector basically develop through social approval and satisfy community functions. Thus, economic (management) activity as the defining characteristic of the social economy becomes subordinate to the social funciton.

In several countries social economy is based on community or solidarity (e.g. South American countries, France, Spain). Organizations can be formal or not formal and they primarily operate with community approval and participation. The opposite is seen in Austria where social economy is defined as those organizations providing social services, duties and the type and quality of their cooperation in the course of performing public tasks.

While the French solidaristic economy shows greater independence from the state, in Austria the organizations' independence from the state cannot be considered a sole criteria for determining if it is in the social economy. Furthermore, under certain conditions even market/private organizations may be a part of the social economy system as well. The Austrian interpretation is fundamentally based on the historic societal role of the pluralistic system of 
providing welfare services and the new public management of the state (Pollit Bouckaert, 2011) with the purpose of providing higher quality and more costeffective services.

Other approaches try to classify social economy according to the systematic function of its organizations instead of its economic function. According to John Pearce's definition, the organizations that are part of the social economy have the following characteristics:

- they have a social mission and function, that is they provide resources for the society

- they perform economic activity that cannot undermine the social mission

- they are a non-profit type - that is the aim of the management is community benefit instead of private profit

- they contribute to the maintenance and conservation of the community resources for community future generations

- they operate using transparent and democratic operational methods

- they are independent of both state and market external control (Pearce, 2005).

The author in one of his other works (Pearce, 2003) provides a kind of systematic summary of the social economy sector (social enterprise): community enterprises, community insturance companies and pension funds, fair trade enterprises and firms (social enterprises) and voluntary and charitable organizations performing economic activities as well can fall into the area of social enterprises.

Therefore, the concept can be interpreted broadly, it can include a wide range of organizations from non-profit to for-profit ones through organizations with 
social missions. According to certain interpretations a part of non-formal organizations may belong to the field of social economy if its operation meets the above criteria.

\section{Conceptual system of social economy in Hungary}

\section{Non-profit - civilian?}

The Hungarian approach has not been quite clear yet, it is not possible to create a uniform Hungarian definition. The first publications on this topic focused on the social activity of the non-profit sector and its impact to promote employment (Csoba, Frey). Civil movements in the years following the change of regime had important functions and employed a significant number of employees typically in the service sector field. The civil sector was intended to play a major role in "the catching up to the EU countries" process. Thus, so in the first publications on this topic (Frey, 2007) social economy was viewed as parallel to the civil sector.

\section{Social enterprises}

Publications can also be found interpretating social enterprises as belonging to the non-profit sector. According to the authors who write about this topic, the most common concept of social enterprise is an enterprise that has social mission (Petheö, 2009). Relying on broader international literature the author considers the operational philosophy of the enterprises to be the starting point.

Petheö (2009:29) mentions other approaches as well. "Social enterpreneurs, in addition to fully being characterized by social responsibility, conduct viable busi- 
ness in the market sense. They give life to business enterprises by interpreting market signs in the context of social, environmental and ethical changes. Compared to traditional enterpreneurs, the most significant difference is that the mission of the social enterpreneur is social development." This approach, however, does not place the non-profit operational characteristics as central.

Legally, these Hungarian enterprises are distinguished from for-profit ones by their non-profit operational practices. Currently (2015) in Hungary social cooperatives and non-profit limited liability companies can be interpreted as nonprofit economic companies or enterprises. For non-profit limited liability companies the legislature determines what is prohibited in the distribution of the profit and that the profit should be involved in capital expenses of the organization or should be used in more provision of services. "Non-profit" should be part of the name of the company. However, changes in the process of founding a company since 2014 are not favourable for non-profit Ltds. Foundations do not benefit from a simplified process and additionally the fees for creating a foundation have been increased. For those limited liability companies that are already established they are entitled to the benefits that are determined by the law for non-profit organizations.

The overall conclusion is that non-profit Ltds will not provide opportunity to people with little money to exit from their social disadvantage position or unemployment, it will be rather the companies organized for serving public duties and founded by local governments that will form the majority of these types of organizations. 


\section{Social cooperatives?}

The role and function of the sector promoting employment and economic performance started to push the interpretation of the social economy towards social cooperatives starting in 2006. The fact that both "social" and "cooperative" were treated with reservations in Hungary (one was based upon the forced evolution of the Hungarian cooperative system based on Soviet example ${ }^{1}$ ) the nascent cooperatives also had face several other difficulties.

Still it was the newly formed cooperative system that protested the most against the regulation of social cooperatives. They did not want to have competitive partners in the cooperative networks that could be part of the competition for state or community support. The legal regulation of the social cooperatives ${ }^{2}$ was immediately followed by project proposals of the National Employment Fund assisting in the formation of cooperatives to boost the development of the sector. The first experience, however, did not provide good results. During this period of financing only very few of the cooperatives that were created using the proposal managed to survive (Németh, 2011).

Field studies revealed that the social cooperatives did not determine precise economic targets; instead they wanted to extend their activities in several directions at the same time. It was defined as the typical characteristic of the organizations operating in the area of social economy (Petheö, 2009), and one of the main reasons of their non-visibility in the social economy was the lack of experience and business ability.

\footnotetext{
${ }^{1}$ The forced collectivisation of agriculture carried out in several waves during the $1950 \mathrm{~s}$ caused serious trauma to the farming population living from agriculture.

${ }^{2}$ Law 2006/X on social cooperatives and 141/2006 (VI.29.) Governmental Decree
} 
One of the studies related to the volatile operation of the social cooperatives reached the conclusion that their social mission including a clear goal, the promotion of employment for disadvantaged people (Petheö et al, 2010), could be reached only briefly without state interventions. The authors therefore urged the intervention and the participation of the state into the life and operation of the social cooperatives.

During the later part of the 2007-2013 EU financial period, social cooperatives actually could be characterized as growing like mushrooms. During the time of heavy rain (calls for proposals) cooperatives emerged like mushrooms but when the application periods were over only one out of seven was able to operate on their own (Németh, 2011), while the others were looking forward to the next support from the state.

\section{Social cooperations - redesigned}

State interventions basically supported fewer bigger organizations rather than supporting several small ones.

The amendment of the cooperative law resulted in a particular re-organization process. As a result of the amendments of the 2011, 2012 and 2013 law $^{3}$ even local goverments, their associations, non-profit charitative organizations and ethnic local governments could also be members of social and employmentoriented cooperations.

The local government could get a so-called investor member position, which provided that fields, buildings or current assets owned by local governments

\footnotetext{
${ }^{3}$ 2011. évi CVI. tv, 2012.évi XXXVII tv., 2013. évi XLI. tv., 2013. évi CCLII. tv. CVI.
} 
could be incorporated as cooperative assets. The cooperatives for employment were strengthened with ethnic local governments were able to lend work force. In addition, involving local governments in cooperatives the changes in the legislation contained several positive rules to facilitate the life and operation of the cooperatives.

It became easier to establish organizations and cooperatives and the members in need could also contribute as a share contribution with their work. From 2012 local governments even have had the theoretical possibility to pass different devices or land for use to residents who participated in public work but gathered in cooperatives at the same time. The law also defined the rules of the members' work and as a result a person who takes part in public work can also work in the cooperative as well. Nonetheless, the National Association of Social Cooperatives (SZOSZÖV) sharply criticized the possibility of local governmental intervention as it might violate the achievement of the classical cooperative principles.

In any case growing expectations with local governments in employment and in revitalizing the local economy require serious intervention into the field of social economy and its consequences cannot be clearly seen yet. It is certain that the government and the local government operate in this area because of its importance.

Governmental actors refer to social cooperations ${ }^{4}$ as belonging to part of the potential in economic production therefore it is not surprising that programs in connection with the establishment and support of cooperatives are supervised by the Ministry of Home Affairs. However, the intention of the government is clear: the cooperative is defined as a way out of public employment for the local

\footnotetext{
${ }^{4}$ http://www.kormany.hu/hu/belugyminiszterium/onkormanyzatiallamtitkarsag/hirek/ertekteremto-munkat-vegeznek-a-szocialis-szovetkezetek
} 
population. It is a pity that practice proves to be completely different in many cases and the public employment function of the local government and its duties undertaken in the cooperatives merge.

In light of the above mentioned facts it is worth returning to the concept of the system applied in Hungary. During the 2007-2013 EU finance period, support to organizations belonging to social economy was provided to operating social renewal programs. This is why Hungarian calls for proposals defined the concept of social economy as follows:

"Private type groups of enterprises that were formed within formal frames and have decision-making freedom and voluntary membership. They were formed to satisfy the needs of their members through market, producing goods, providing services, insurance and finance. In addition the decision-making and the distribution of any profit or gain do not link directly to the capital invested or fee paid by the members and where each member has only one vote.

In addition social economy includes private type organizations formed within formal frames and has decision-making freedom and voluntary membership, and provides non-market type services to households. The financial actors who established, monitor or finance these organizations cannot expropriate the potential profit surplus. According to the definition the common characteristics of the sectors of the social economy are the following:

- They are private sectors, that is they are not part of the public sector therefore they are not monitored by it

- They operate within formal organizational frames, thus they can usually be regarded legally as persons 
- They have decision-making authonomy, which means they can elect or fire their governing body free and they can freely monitor and organize their activities

- Their membership is voluntary and it is not compulsory to join

- The distribution of any potential profit or profit surplus among its members is not proportional with the invested capital or with the paid fee but with the rate of their activities for the organization or with the rate of their cooperation with the organization.

- They engage economic activity, which satisfies the needs of individuals, households and families. This is why social cooperatives are regarded as organizations serving the benefit of people and not organizations creating capital. Although they use capital and other non-financial type resources for their operation they do not serve the interest of creating capital.

- They are democratic organizations. With the exception of some voluntary organizations, which provide non-market type services for households, primary organizations of social cooperatives apply the principle of ,one member - one vote" in their decision-making processes, regardless to the capital invested by the members or the paid fee. Organizations operating on other levels are also organized democratically. The members have majority or exclusive control over decision-making powers within the organization.

Social economy is primarily a market-orientated, producing, trade and service activity that is a community enterprise operating within an organizationalnetwork frame that focuses on the elimination of unemployment. Its basic values are volunteering and cooperation, solidarity and responsibility, social commitment enhanced by the prohibition of profit distribution. The characteristics of social cooperatives that meet both the broad definition of the social economy and the basic principles of the cooperatives: 
- volunteering and open membership,

- democratic member control,

- economic participation of the members,

- autonomy and independence,

- education and training of the members,

- cooperation among the coperatives

- commitment to the community.

The development of the social economy should be separated from the system of the public employment. However, they are connected because it offers an opportunity for a further step towards the open labour market for those participating in public employment, but it is not a part of public employment",5

It can be seen what has happened over the years in the concept and interpretation of social economy.

\section{Social economy, the revitalizing role of local economy}

Local governments are responsible for the revitalization of the local economy. On one hand such activities may decrease globalization induced vulnerability and dependency and on the other hand may compensate a little for the failures that the nation-state suffered in this area. There is almost a feudal illusion of locally producing and self-sustainable municipalities aiming to exclude the global economy and to focus exclusively on the development of a community

\footnotetext{
${ }^{5}$ Development of the social economy - Support of social cooperatives targeting selfsustainability in convergence regions TÁMOP-2.4.3-D-1-13/1
} 
economy. Local economy offers not only an option of the in-site selling of the goods produced locally but it may rebuild and strengthen community relationships as well. As previously mentioned, local governments can have very important roles in this area.

Attempts to revitalize local economy:

- Local markets: local people can sell their goods in the local markets, thus, local people can buy local products.

- Local currency: local currency is a voucher that can only be used locally. It usually strengthens local economy in municipalities where there is tourism and the guests can use the local currency for certain discount.

- Self-sustaining communities: the local government undertakes certain management tasks where the local population is involved. For example, production activity is performed on the lands of the local government. The producer is the local government itself or one of the non-profit enterprises of the local government. It is frequent in Hungary that the local inhabitants participate as public employees in the program. The produced goods are used in community services (e.g. foor for children).

- Revitalization of the economy, development of tourism built on local values. These programs can be succesful in areas that have appropriate conditions for the development of tourism.

Public employment and the role of local government in public employment help to ease economic vulnerability of the people. This provides work, however, there is little information available on its impact on local communities. 


\section{Community economy development}

Programs related to assisting the economic prosperity of communities belong to one of the border areas of social economy. Initiation is often informal, however they directly contribute to the improved prosperity of local communities. In Hungary more and more community development programs can be found.

\section{The role of the state in support of the social economy}

The expansion operation of organization of the social economy is basically determined by its relationship to the nation state sector. Without a certain level of recognition, acceptation and support the operation and the development of the social economy cannot be imagined. With regard to the recognition by international organizations (ILO, Worldbank, EU bodies) toward the social economy, the existence of the organizations of the social economy is legal in and beyond the EU member states although the interpretation of the concept may not be the same.

The attitude of the nation states may be different:

- Acceptance, tolerating or legitimization of the operating mechanisms of the community or grassroot movements by the power of the community

- Providing legal benefits e.g. at registration, provision of tax breaks to the organization or to the customers of the organization

- Market regulating mechanisms, e.g. preeminent provision to local initiation, state orders for performing public tasks, or providing services related to public tasks 
- Targeted social assistance for the revitalization of the social economy, e.g. financial support for founding or launching organizations, porfessional support services, e.g. professional counseling, professional services (tenders/grants), etc.

There is no doubt, however, that the social economy sector will be able to develop and meet state and/or social expectations depending on how much opportunity it gets to operate in this area. Following the analysis of studies, Hungary like several other Eastern-European countries, is considered to be among the less developed countries with regard to the social embeddedness of the social economy. Therefore, the issue of state support and the involvement of the state are becoming more salient.

\section{Alternatives of the social economy during the nationalization}

A clear answer to the performance of the non-market and non-state tasks of the social economy was given by the many non-profit organizations launched after the change of the regime. The increasing number of those employed in the civil sector, their increasing free time, as well as cultural and social engagement stopped after a time. The number of the classic civil organizations was 55 per 10,000 inhabitants in $2010^{6}$, but the distribution of the organizations was/is typically uneven with two-third located in the central Hungarian region.

The number of the volunteers actively participating in the sector was 420,000 in 2010. The composition of the organizations has changed in recent years, with the new non-profit economic management companies generally operating with a larger budget compared to the former so-called classic civil organizations. Al-

\footnotetext{
${ }^{6}$ CSO: The role of the non-profit sector in the regions, August 2012.
} 
most half of the funding of the organizations comes from public funds and this percent is even larger for organizations performing social tasks. In recent years non-profit organizations working in the social field have been characterized by a growing dependence upon government monies, which are mainly the result of outsourcing of state duties (Nárai, 2005).

A tendency can be seen in the organization of the public tasks where the state tends to bring more areas into its own organization and control. This may adversely affect non-profit organizations performing public tasks because both supply and operations be under state control that could ultimately result in fewer resources. An example the state outsourcing of the educational, social and childcare tasks in 2010 is worth mentioning because almost one-fourth of the nonprofit organizations worked in this field. The outsourcing of these tasks to the powers of the state mainly affected the local governmental sector and it gave room to undertake new or formally civilian-coordinated tasks.

In some cases regulation defines public tasks as exclusively state tasks, so civilians specialized in performing these tasks will be left out. Tenders for EU resources providing and developing public services are designed for state institutions and local governments therefore civil actors can get involved only indirectly ${ }^{7}$. Consequently, civilians must go to the state or its organizations to obtain state directed (required) tasks but they must also go for proposals financed from public funds.

\footnotetext{
${ }^{7}$ TÁMOP 5.3.6-11/1 Complex Plant Program, which was a tender just for the Türr István Training and Research Institute. The National Rehabilitation and Social Office has a similar role, or the National Family and Social Policy Institution had similar tasks previously.
} 


\section{What will the future bring?}

At the time of writing this article the next funding cycle of the European Union has already started (2015). Revitalizing of the economy has become an important goal among the priorities for 2014-2015. The government will spend about the $60 \%$ of its total funds on this goal. In the preparation document social economy is mentioned as a tool that can increase the performance of the economy and employment.

This section is no longer classified under the Social Renewal or to the Human Resource operational programs but has been moved to the Economy and Innovation operational programs indicating the link with the sectors's economic function. The social enterprise term is typically used. Development of the sector is proposed in the documentation as a centralised one. The keywords are "sustainable business models", "innovation", "expansion of the employment" and "sustainability". It has not been clarified which players from the broad sector of the social economy will recognise if they are eligible when tenders appear.

\section{Social economy and social work}

In this chapter the author attempts to clarify the relationship of the social work profession with organizations that can be defined as parts of social economy on the basis of any approach. It will discuss why it is difficult for social experts to work in organizations of the social economy and why it is of great significance to move in this direction. 


\section{Social work values and its deformation}

The reason for rethinking social worker training and the profession linked to the regime change was the appearance of professionals in the support system who are able to quickly focus their high level general knowledge to applied fields and are therefore able to respond to unpredictable social problems. The claim for the practical formation of social policy is that social workers are clearly expected to critically analyze social distribution and to pursue social justice (Budai, 2010). The economic, social and political regime change was somewhat followed by the „regime change" in the social profession. The new spirit of social work broke with the national, historical roots of the profession in many respects and the professional methods taken over from the English practice proved to be hard for Hungarian professionals to adopt. Hungarian service systems developed rapidly and the professional image was not able to properly follow the changing times and the world. There is no doubt that the Hungarian social work profession in its foundations, methods and values has remained essentially unchanged but its priorities have changed during the twenty years.

\section{"Welfare social work" service models, care oriented helping work}

The enthusiasm of the profession was accompanied by a rapid development in the social system, however, even in this situation social work was not able to strengthen its own national theory, identity and professional separation. ${ }^{8}$ In one of the methodologies in the system of the professional activities, defined as

\footnotetext{
${ }^{8}$ The slowness in the development of the profession is apparent and can be traced back to several causes, however, their analysis is not the subject of this study. Read more details in Budai István (2010): After twenty years - self-critically Esély 4.
} 
"welfare social work" by the author, the main task of professionals is to provide state social benefits to entitled individuals and families.

The attention of the social professionals working in the support system and "experiencing it from inside" focused on the application of services and procedures $^{9}$ and not on a critical examination or change of the system. This peculiar image was strengthened by strong state authorization, which replaced social approval ${ }^{10}$. This increased one of the basic ethical dilemmas of social professionals, the value choice between the disadvantaged, the different target groups of social work and the expectations of the state (society) (Solas, 2009).

The methods are typically administrative techniques. Procedures accompanying the helping process have strengthened, which have been mistakenly interpreted as the dominance of case- work as one client could be found as the reason for each case. The reason for this mistake was that unlike casework it is not the client who is the starting point of the workflow but the process - that is the work is not client centered but service (system) centered. The client is therefore the subject of the professional intervention. Client-centered work basically assumes a certain level of sytem-independent way of thinking from the helper. ${ }^{11}$

\footnotetext{
${ }^{9}$ There are historical reasons for the strengthening of this system. A significant part of those who work in the system of personal social service work in caregiver positions with lower qualifications (Csoba, 2006).

${ }^{10}$ Public authority means the support of the development of the training and support systems. Social approval is the general acceptance, respect, and support of the activity. It can be materialized in the form of voluntary movements, however, only a few examples can be found in the recent Hungarian practice. The lack of the civic roots of social responsibility can be understandable, this is why the author notes that there is a claim for the professional activity but the profession was accompanied by little activity of the citizens.

${ }^{11}$ See e.g. the case manager work in international practice or the American tradition of case work.
} 
This kind of change in the environment of professional work has several side effects that affect the profession even today and that make the above statements more clear.

\section{Community work methods are fading into the background}

One of the adverse effects is the forcing of community work methods into the background, which is surprising because from the beginning of the $90 \mathrm{~s}$ the Hungarian community development movement was quite productive. It initiated and developed its practical and methodological basis by itself. ${ }^{12}$ If in the toolbox of the social workers, cooperation with other communities and the strengthening of the communities had been a more frequently applied method, then the belief that social workers deal only with the poor and those living in poverty, would have been reduced. In English-speaking countries the methods of the community social work had an important role in social work (Gosztonyi, 1994). The protection of the civil and social rights, and representation of the oppressed seemed to be strange for most of the Hungarian professionals as they basically suppose that the culture practices and supports civil rights.

The lack of the social participating supporting role of social work is considered to be critical by the represetatives of the field as well. "Experts, however, rather "hide" personal assistance from social work and it is doubtful if it is possible to develop an equal partnership with those who they forced into a client relationship. Community participation would require a developmental activity

\footnotetext{
${ }^{12}$ For more details see the work of Vercseg Ilona, Varga Tamás, Péterfi Ferenc, Harkai Nóra published on this topic.
} 
from the colleagues of this profession that would also aim to create a change in the citizenship relations of those they help, support and care for, however, such a basic task or role is still foreign to most of the workers of the social institution system."(Nizák - Péterfi, 2007).

\section{Care-oriented work}

Professional activities that are based on caring for clients is a significant part of the helping work and perhaps it is the reason why the concept of social work and social care are merged.

The service provision role of social workers is further reinforced by the restriction of helping activities to institutions and the profession itself has done little to change this situation.

\section{Professional - non-professional relationships in social work}

In addition, the rebirth of the profession involved a kind of compulsive need for self-identification that was made more difficult by the existing circumstances of the profession (only a small number trained, and intervention methods oriented to care and crisis-intervention). Searching for a social work identity by professionals was a source of several conflicts; some that had to be fought in the local society but some in the workplace as well.

While social work in the English-speaking countries tended to strengthen its own professional image with the development of its own theoretical systems this failed to happen or could be detected only minutely in Hungary. 
One of the important elements in searching for a professional identitly was the separation of the non-professional and professional roles and competencies. Social workers tended to distance their acivities from non-professional, voluntary and philantropic values and actors, thus confirming the quality and raison d'etre for their professional activities. The operation and financing mechanisms of the public welfare sector only further augmented this process. E.g.: in personal and social services even today the regulation and recognition of volunteering are still very sketchy and their appearance in the clients' helping role was totally unimaginable for a long time. The applying rules paradoxically when applied did not follow the new social work professionalization claims as they developed the legal conditions to accept people with different qualifications as skilled employees in professional jobs. ${ }^{13}$

Thus, social work may distance itself from valuable resources. Social Work finds it difficult to cope with voluntary helpers and does not find places and tasks for them in organizations. It stereotypes the role of the client, which is clearly detrimental to the application of the methods that make clients able which is discussed in more detail later.

\section{Client image}

The duality of the image of the helper and the client and the concerns about the interoperability of these concepts arose from the therapeutic approach of social

13 See more details in the resolutions of the Hungarian Social Association for Professionals in training (Education Association or ISKOLASZÖVETSÉG), where proposals have been given to crystallize these conditions with more or less (rather less) success. 
work. In this image of the model of the social case work the client cannot cope with the problems without help, this is why the social worker must intervene. Social work theories developed in the English speaking countries consider the activities of the clients' and recovered clients' self-help, self-organized groups and their effect of their support a basic resource. But in the Hungarian adaptation of social work much less emphasize is put on these activities.

In the client image and the client-helper relationship the process of onesidedness was reinforced by the restriction in the competent action of helpers, which can be traced back to the priorities in the maintainence and service functions. Helpers working in the organization primarily use the services of the organization as a resource and secondary those helping competencies are used that are accepted and permitted within given organizational frameworks. Therefore, professional competencies are essentially restricted by legal, professonal procedures and organizational priorities. Network cooperation, case management and teamwork do not appear as professional priorities if they have not been defined as having organizational value. ${ }^{14}$

\section{Changing socio-political processes - perception of poverty}

One of the important responsibilities of social workers is "to call the decisionmakers' and the public's attention to the responsibility of the decison-makers, the society and the institutions for the development of deprivation and suffering

\footnotetext{
${ }^{14}$ Examples are: case conference in child potection or the signalling system meeting that was made compulsory by the child protection law for those working in the system, however, its effective operation still means challenge.
} 
and for the hindering of their mitigation." $" 15$ The increase in social inequities was followed by the rebirth of the social work, and it became an important task of social workers to actively influence socio-politics, however, neither an effective methodology nor its culture has developed.

A significant number of social workers would have to represent their clients over those providing the maintainence for clients (local government) or another funder and this, as it has been mentioned, seems to be a very difficult task from "inside". The helpers have been "sucked" into the state welfare systems and their activities have been narrowed, which caused difficulty because in many cases problems requiring complex social programs had to be dealt with using individual helping methods. Beginning at the end of the 1990s, in certain areas, ideologies that strengthened professional administrative and official roles were promoted which provided new tools to professionals dealing with families, children, those living in poverty or people searching for jobs. Administrative and controlling roles were hard to reconcile with the helping role (Pataki, 2006), but a part of the professionals seemed to accept these methods as an open, simple and legitimate tools even though this period lacked methodology or tools (Budai, 2010).

\section{Foreign words}

Moreover only a few professional methods appeared and spread in social work that looked at clients from a different perspective and emphasized a partner-like, active role, while the international practice of social work called the attention to

${ }^{15}$ Social Work Code of Ethics point10. Social Work Association, 2011. 
these approaches. The International Association of Social Workers in 2001 defined social work as follows: "Professional social work promotes social change, problem solving in human relations and the empowerment of those deprived from power and the liberation of people in order to reach greater wellbeing...". 16

This international concept calls professionals' attention to protect the impairment of social rights won within the frameworks of the civil welfare system and to the defence of the rights of clients. Within the recent helper-client relationsihps even the translation of the words seems to be difficult and professional steps in this direction only appear on projects.

The perception of radical social methods is similarly careful and conservative in Hungary. Recently the state punitive actions against the poor and homeless people have resulted in triggering a kind of radical initiation by non-formal professional groups and activists, which were accepted with mixed feelings by professionals ${ }^{17}$, who typically kept distance from the programs.

\section{Institutionalization}

The structure of social services and the methods applied in organizations basically determine the scope of activities, the value system and the competencies of social work. The institutionalization of social work in EasternEuropean countries threatens the loss of profession values and the identity of social work. The young profession (ony 25 years old) has integrated into a service system that has difficulties with changing its traditions and which can more

\footnotetext{
${ }^{16}$ IFSW 2001

17 See: the actions of The City is for Everyone Movement (http://avarosmindenkie. blog.hu/) and the New Approach Movement (http://ujszemlelet.blog.hu/)
} 
and more be characterized in Hungary by centralization. According to Szabó Lajos (2014) if there is a standard form measuring needs then the helper will not need the complex activity of getting to know the clients or exploring their problems, which results in the distortion of the values, culture and ultimately the identity of the profession.

\section{The need for new guidelines}

Given the change in the social situation, a renewal of the profession is urged by both professionals and trainers. Openess towards the 2010-2012 project proposals $^{18}$ can be a good example. Several programs tended to strengthen the elements of work in the training of professionals based on community participation while others developed educational methods and another wanted to introduce new methods and approaches to the professionals (Hegyesi, 2012; Baráth, 2012).

Overall the professional image can be characterized by a late and slow professional development, which basically could not keep up with the rapid development of the service system. Later, it was not aware of its professional frameworks and could not stabilize its positions and as a result it became much more vulnerable to the shape and value change on social issues. As a result helping work can be characterized by institutional, service, administrative, procedural competencies and the partnership-like cooperation with clients is becoming less and less important.

\footnotetext{
${ }^{18}$ TÁMOP 5.4.4 Renewal of social trainings
} 


\section{What competencies are needed in social economy?}

Returning to the basic question of the analysis, concerning the tasks and role of social workers, a question arises: If social workers work typically in state sectors and in institutional sectors organized under the auspices of the state then how they can particpiate in the revitalization of social economy and in the support of its organizations?

Some years ago the author visited the restaurant of an Austrian organization called Inigo, where the employees were former prisoners and wanted to reintegrate into society. The chef was a social worker that assisted the work of the organization by using common activities and tried to help the workers achieve personal success.

Social work views this type of social work as embedded in a common activity, in partnership with the helper's exemplary behaviour and without the framework of a formal, institutional organization. The behaviour of the helper evokes an old model, the settlement, which started at the end of the $1800 \mathrm{~s}$ with its work embedded in the community in contrast to contemporary poverty ideology and policy. Some of the core ideas of the settlement movement are worth mentioning:

- to learn and teach: that is the helper also learns in the common cooperation and teaches those entering the settlement;

- the principle of percolation: an important goal of the settlement is the nondirective transfer of culture and values. One of the important methods is being an example;

- common activity based on respect for community initiation and support.

Hopefully the analogy cannot be considered a devil-like one but in the fields of social economy the professionals could promote the strengthening of self- 
determinative and empowerment abilities in disadvantaged groups embedded into common economic activity, common activity, giving example and advice, utilizing the community resources, supporing the organization, strengthening the competencies of employment and management.

It is perhaps the social work methods based on community work and community development that may contribute the most to the development of the organizations and the work of social economy. Social workers can have an important role in this field but it is questionable how much the education and the practice prepare the professionals to this duty?

According to the key competency examination of social workers working in this field (Patyán et al. 2012) the most important knowledge determined by professionals is the ability of "treatment with clients" while ,interest representation, partnership, cooperation with clients and development of empowerment competencies were mentioned among the weakest competencies.

Therefore social trainings must initiate fundamental changes in the value system. In addition to therapeutical, service profile the cooperative values should also appear and professional practice should be adapted to them. Practice fields can be social cooperatives, local-governmental programs helping local economy, local initiation and it would decrease the future professionals' distrust towards this area and the lack of information. Community work methods, volunteering, helping local initiations and support based on the participation of the cooperatives can strengthen an old-new value system and area of social work. 


\section{References}

Baráth, Á. (2012): Spiritualitás és szociális munka. Esély 1.

Budai, I. (2010): Húsz év után - önkritikusan. Esély 4.

Hegyesi, G. (2012): Új eszközök, módszerek és megközelítések a segítő szakmában. Esély 3.

Csoba, J. (2007): A szociális gazdaságot életre hivó folyamatok. In: Frey Mária (eds): Szociális gazdaság kézikönyv. OFA Budapest.

Frey, M. (2007): A szociális gazdaság fogalma. In: Frey Mária (eds): Szociális gazdaság kézikönyv. OFA Budapest.

Nárai, M. (2005): Civil szervezetek szerepvállalása a szociális ellátás, szolgáltatás területén Esély 1.sz.

Németh, L. (2011): Tényszerü adatok a szociális szövetkezetek müködéséröl. www.szoszov.hu

Nizák, P. \& Péterfi, F. (2005): A közösségi részvétel - társadalmi és hatalmi beágyazottság. Nonprofit Szektor Analízis. In: Márkus Eszter (eds): Ismerd, értsd, hogy cselekedhess. Tanulmányok a részvételi demokrácia gyakorlatáról. NOSZA Egyesület Budapest 2005.

Patyán, L., Kovács, J. \& Kiss, J. (2012): Szociális munkások segitö kompetenciáinak vizsgálata. In: Kozubovszka I. B. (eds): Social Work and Specialists Training within the Bologna Process demands. pp. 63-66. 
Pearce, J. (2003): Social Enterprise in Anytown. London: Calouste Gulbenkian Foundation

Pearce, J. (2005): The Future of Social Enterprise in the UK. www.wiselink.ie

Petheö, A. (2009): A vállalati társadalmi felelösségen túl - a szociális vállalkozás. PhD értekezés Budapest, 2009.

Petheő, I., Győri, Zs., Németh, B., Fekete, N. \& Simon, F. (2010): A szociális szövetkezetek müködési modelljének kidolgozása a foglakoztatás elösegitése érdekében. Budapesti Vállalkozásfejlesztési Kutató Intézet Nonprofit Kft. Budapest.

Pollitt, C. \& Bouckaert, G. (2011): Public Management Reform: A Comparative Analysis - New Public Management, Governance, and the Neo-Weberian State. SAGE International Institute of Administrative Sciences

Szabó, L. (2014): A szakmai kultúra és az intézményes kultúra, valamint az intézményi és társadalmi környezet szerepe a szociális munkában. Párbeszéd, Szociális munka folyóirat Vol. 1. No. 1-2.

Számadó, R. (2011): Módszertani kézikönyv a szociális szövetkezetek megalakulásától a fenntartható müködésig. OFA Budapest.

Solas, J. (2009): Milyen társadalmi igazságosságra törekszik a szociális munka? Esély 5.sz. 


\section{List of Contributors}

\section{Editors:}

Gergely Fábián, Dr. habil. sociologist, vice-dean of University of Debrecen Faculty of Health, Head of Department Social Sciences, Hungary

Andrea Toldi, language teacher, CEEPUS coordinator, expert of international and diplomatic relations, University of Debrecen Faculty of Health, Hungary

\section{Reviewers:}

Béla Szabó, PhD, assistant professor, Hungarian Department of Sociology and Social Work. Director of distance learning - Social work Babes-Bolyai University, Cluj-Napoca, Romania

Prof. Mihály Fónai, Dr. habil. sociologist, Head of Department of Social Science and Public Policy at Faculty of Law, University of Debrecen, Hungary

Prof. Thomas R. Lawson, PhD., Hon. Dr., Hon. Dr. Sc., FUAS Professor and Director of International Programs Kent School of Social Work, University of Louisville, Kentucky, USA

\section{Authors:}

Anna Delage, Master of Sociology, charged of missions for Social work training and for research, Angoulême, France

Yves Coutand, Master of Sociology, International coordinator for Regional Institute of Social Work, IRTS, of Poitiers (retired), France

Gerhard Melinz, Dr. habil. Social and Economic Historian and Political Scientist; Lecturer at the Department of Social Work, FH Campus Wien (University of Applied Sciences Vienna) and at the University of Vienna, Department of Economic and Social History, Austria

Astrid Pennerstorfer, Dr. Assistant Professor at the Institute for Social Policy, WU Vienna University of Economics and Business, Austria and lecturer at SOWOSEC, FH Campus Wien (University of Applied Sciences Vienna), Austria 
Brigitta Zierer, PhD, Professor at the Department of Social Work, Head of Social Economy and Social Work (SOWOSEC) at FH Campus Wien (University of Applied Sciences Vienna); Social Worker, Supervisor, Organizational Consultant, PhD. in Political Science and Communication Science, Austria

Ondrej Botek, PhD., associate professor - Social Worker and Psychotherapist, Head of Department of Social Work, Trnava University in Trnava, Slovakia

Šárka Ulčáková, Mgr. Doctoral student of social work, University of Ostrava, Faculty of Social Studies, Czech Republic

Šárka Dořičáková Mgr. Assistant professor and doctoral student of social work, University of Ostrava, Faculty of Social Studies, Department of Social Work, Czech Republic

Witold Mandrysz, $\mathrm{PhD}$, sociologist, social worker, Social Work Unit, Institut of Sociology, University of Silesia in Katowice, Poland

Adina Rebeleanu, PhD, senior lecturer, Faculty of Sociology and Social Work, Babes-Bolyai University, Cluj-Napoca, Romania

Livia Popescu, $\mathrm{PhD}$, professor, Faculty of Sociology and Social Work, BabesBolyai University, Cluj-Napoca, Romania

László Patyán, PhD student, social worker, associate professor at the University of Debrecen Faculty of Health, Hungary 